Prepared in cooperation with the U.S. Environmental Protection Agency, Great Lakes Restoration Initiative

\title{
Water Pressure and Ground Vibrations Induced by Water Guns near Brandon Road Lock and Dam and Lemont, Illinois
}

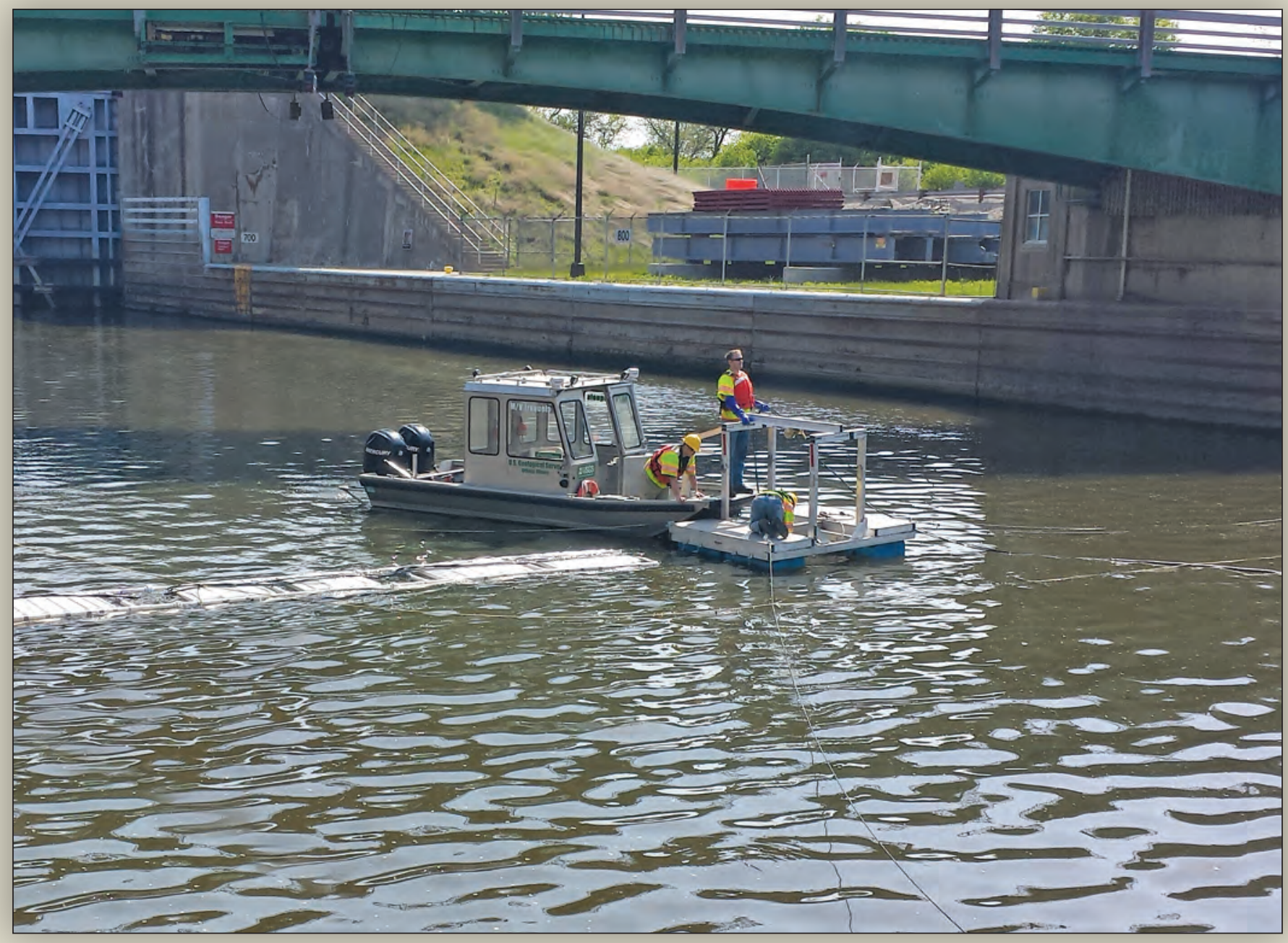

Scientific Investigations Report 2017-5153 
Cover: Photograph showing water gun and hydrophone boom setup at Brandon Road Lock and Dam near Lemont, Illinois. Photograph by Carolyn Koebel, U.S. Geological Survey, May 2014. 


\section{Water Pressure and Ground Vibrations Induced by Water Guns near Brandon Road Lock and Dam and Lemont, Illinois}

By Ryan F. Adams, Carolyn M. Koebel, and William S. Morrow

Prepared in cooperation with the U.S. Environmental Protection Agency, Great Lakes Restoration Initiative

Scientific Investigations Report 2017-5153 


\title{
U.S. Department of the Interior \\ RYAN K. ZINKE, Secretary
}

\section{U.S. Geological Survey William H. Werkheiser, Deputy Director exercising the authority of the Director}

\author{
U.S. Geological Survey, Reston, Virginia: 2018
}

For more information on the USGS — the Federal source for science about the Earth, its natural and living resources, natural hazards, and the environment-visit https://www.usgs.gov or call 1-888-ASK-USGS.

For an overview of USGS information products, including maps, imagery, and publications, visit https://store.usgs.gov.

Any use of trade, firm, or product names is for descriptive purposes only and does not imply endorsement by the U.S. Government.

Although this information product, for the most part, is in the public domain, it also may contain copyrighted materials as noted in the text. Permission to reproduce copyrighted items must be secured from the copyright owner.

Suggested citation:

Adams, R.F., Koebel, C.M., and Morrow, W.S., 2018, Water pressure and ground vibrations induced by water guns near Bandon Road Lock and Dam and Lemont, Illinois: U.S. Geological Survey Scientific Investigations Report 2017-5153, 55 p., https://doi.org/10.3133/sir20175153.

ISSN 2328-0328 (online) 


\section{Contents}

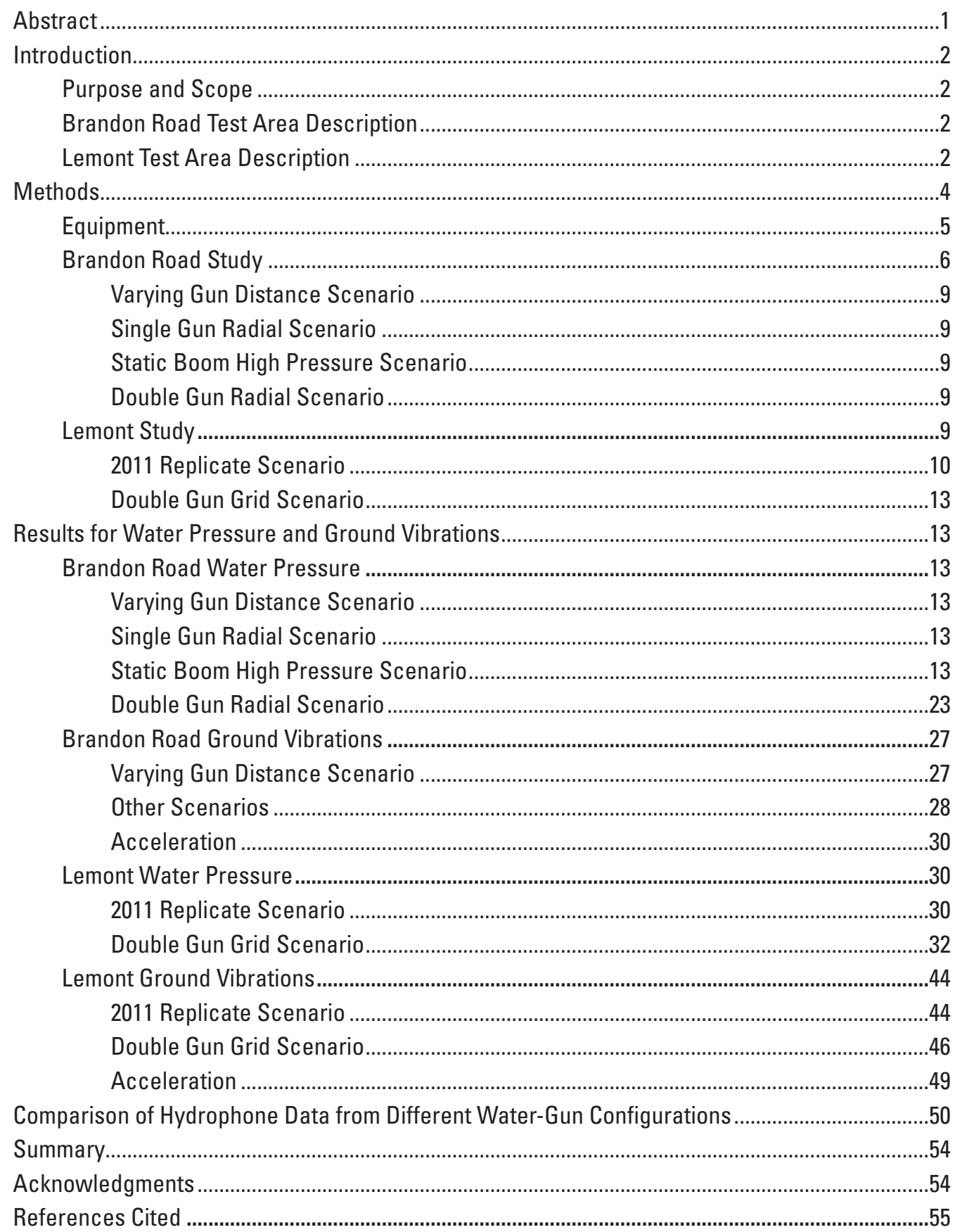




\section{Figures}

1. Water gun firing schematic

2. Map showing location of study area and major sensor groups, Des Plaines River, near Joliet, Illinois

3. Map showing location of Lemont water gun test and data collection areas, Chicago Sanitary Ship Channel, near Lemont, Illinois.

4. Graph showing velocities of near and far Instante ${ }^{\circledR}$ and near and far R.T. Clark surface geophone pairs from a 2,000-pound-per-square-inch shot located 50 feet from canal wall.

5. Image showing water gun, geophone, and accelerometer positions for varying gun distance scenario, Brandon Road study, Des Plaines River, near Joliet, Illinois.

6. Image showing water gun, geophone, and accelerometer positions for single gun radial scenario, Brandon Road study, Des Plaines River, near Joliet, Illinois.

7. Image showing water gun, geophone, and accelerometer positions for static boom high pressure scenario, Brandon Road study, Des Plaines River, near Joliet, Illinois .....8

8. Image showing water gun, geophone, and accelerometer positions for double gun radial scenario, Brandon Road study, Des Plaines River, near Joliet, Illinois.

9. Cross-sectional schematic diagram and plan view of 2011 replicate scenario, Chicago Sanitary Ship Channel, near Lemont, Illinois.

10. Cross-sectional schematic diagram inset, and plan views of double gun grid high pressure and low pressure scenarios, Chicago Sanitary Ship Channel, near Lemont, Illinois

11. Graph showing effects of equipment malfunction on waveform data from a single hydrophone, Brandon Road study, Des Plaines River, near Joliet, Illinois

12. Graph showing pressure data from a hydrophone placed 1 foot from testing wall at depth of 8 feet below water surface, Brandon Road study, Des Plaines River, near Joliet, Illinois

13. Map showing pressure measurements at water surface from a single 80-cubic-inch water gun fired at 700 pounds per square inch, Brandon Road study, Des Plaines River, near Joliet, Illinois.

14. Map showing pressure measurements at a depth of 2 feet below water surface from a single 80 -cubic-inch water gun fired at 700 pounds per square inch, Brandon Road study, Des Plaines River, near Joliet, Illinois

15. Map showing pressure measurements at a depth of 4 feet below water surface from a single 80-cubic-inch water gun fired at 700 pounds per square inch, Brandon Road study, Des Plaines River, near Joliet, Illinois

16. Map showing pressure measurements at a depth of 6 feet below water surface from a single 80 -cubic-inch water gun fired at 700 pounds per square inch, Brandon Road study, Des Plaines River, near Joliet, Illinois

17. Map showing pressure measurements at a depth of 8 feet below water surface from a single 80 -cubic-inch water gun fired at 700 pounds per square inch, Brandon Road study, Des Plaines River, near Joliet, Illinois

18. Map showing pressure measurements at a depth of 9 feet below water surface from a single 80-cubic-inch water gun fired at 700 pounds per square inch, Brandon Road study, Des Plaines River, near Joliet, Illinois

19. Profiles showing spatial distribution of pressure for a single 80-cubic-inch water gun placed 55 feet from the testing wall, 6 feet below the water surface, and fired at $1,000,1,500$, and 2,000 pounds per square inch, Brandon Road study, Des Plaines River, near Joliet, Illinois 


\section{Figures-Continued}

20. Profiles showing spatial distribution of pressure for single 80-cubic-inch water guns placed 6 feet below water surface and 8 feet below water surface oriented orthogonally to the first water gun, and for two 80 -cubic-inch water guns placed 6 and 8 feet below water surface, respectively, all 55 feet from the testing wall and fired at 1,000 pounds per square inch, Brandon Road study, Des Plaines River, near Joliet, Illinois

21. Profiles showing spatial distribution of pressure for a single 80-cubic-inch water gun 6 feet below water surface, and for two 80-cubic-inch water guns 6 and 8 feet below water surface, all 55 feet from the testing wall and fired at a pressure of 2,000 pounds per square inch, Brandon Road study, Des Plaines River, near Joliet, Illinois

22. Map showing pressure measurements at water surface from two 80-cubic-inch water guns fired at 1,000 pounds per square inch, Brandon Road study, Des Plaines River, near Joliet, Illinois

23. Map showing pressure measurements at a depth of 2 feet below water surface from two 80-cubic-inch water guns fired at 1,000 pounds per square inch, Brandon Road study, Des Plaines River, near Joliet, Illinois

24. Map showing pressure measurements at a depth of 4 feet below water surface from two 80-cubic-inch water guns fired at 1,000 pounds per square inch, Brandon Road study, Des Plaines River, near Joliet, Illinois

25. Map showing pressure measurements at a depth of 6 feet below water surface from two 80-cubic-inch water guns fired at 1,000 pounds per square inch, Brandon Road study, Des Plaines River, near Joliet, Illinois

26. Maps showing pressure measurements at a depth of 8 feet below water surface from two 80-cubic-inch water guns fired at 1,000 pounds per square inch, Brandon Road study, Des Plaines River, near Joliet, Illinois

27. Map showing Pressure measurements at a depth of 9 feet below water surface from two 80-cubic-inch water guns fired at 1,000 pounds per square inch, Brandon Road study, Des Plaines River, near Joliet, Illinois

28. Profiles showing spatial distribution of pressure for a single 80-cubic-inch water gun 6 feet below water surface fired at 700 pounds per square inch, and for two 80 -cubic-inch water guns 6 and 8 feet below water surface fired at 1,000 pounds per square inch, Brandon Road study, Des Plaines River, near Joliet, Illinois.

29. Graph showing changes in velocity at geophones placed 6 and 16 feet from testing wall in transverse, longitudinal, and vertical components, Brandon Road study, Des Plaines River, near Joliet, Illinois.

30. Graphs showing changes in velocity with varying water gun pressure, Brandon Road study, Des Plaines River, near Joliet, Illinois

31. Graph showing transverse, longitudinal, and vertical wall velocities of pressure waves from firing of two 80 -cubic-inch water guns fired at 1,000 pounds per square inch at depths of 6 and 8 feet below water surface, respectively, as measured by geophones 6 and 16 feet inland from wall, Brandon Road study, Des Plaines River, near Joliet, Illinois

32. Graph showing transverse, longitudinal, and vertical wall velocities of pressure waves from firing of two 80-cubic-inch water guns at 6 and 8 feet below water surface, respectively, as measured by three three-component geophones placed 6 feet from edge of channel at various offsets from the center line of experiment, Brandon Road study, Des Plaines River, near Joliet, Illinois. 


\section{Figures-Continued}

33. Graph showing transverse, longitudinal, and vertical wall velocities of pressure waves from firing of a single 80-cubic-inch water gun and two 80-cubic-inch water guns at depths of 6 and 8 feet below water surface, respectively, and all fired at 1,000 pounds per square inch, as measured by geophones 6 and 16 feet inland from wall, Brandon Road study, Des Plaines River, near Joliet, Illinois

34. Graphs showing acceleration of pressure wave velocities as water gun input pressure increases in vertical and horizontal directions, Brandon Road study, Des Plaines River, near Joliet, Illinois

35. Graphs showing pressure measurements at depths of 4, 14, and 22 feet below water surface from two 80-cubic-inch water guns, a single 80-cubic-inch water gun suspended at a depth of 4 feet below water surface, and a single 80 -cubic-inch water gun suspended at a depth of 14 feet below water surface, and all fired at 2,000 pounds per square inch at distances of 30 to 90 feet from the testing wall, Chicago Sanitary Ship Channel, near Lemont, Illinois.

36. Map showing pressure measurements at a depth of 6 feet below water surface from a single 80-cubic-inch water gun fired at 2,000 pounds per square inch, Chicago Sanitary Ship Channel, near Lemont, Illinois.

37. Map showing pressure measurements at a depth of 6 feet below water surface from two 80-cubic-inch water guns both fired at 2,000 pounds per square inch, Chicago Sanitary Ship Channel, near Lemont, Illinois.

38. Map showing pressure measurements at a depth of 14 feet below water surface from a single 80-cubic-inch water gun fired at 2,000 pounds per square inch, Chicago Sanitary Ship Channel, near Lemont, Illinois.

39. Map showing pressure measurements at a depth of 14 feet below water surface from two 80-cubic-inch water guns both fired at 2,000 pounds per square inch, Chicago Sanitary Ship Channel, near Lemont, Illinois..

40. Map showing pressure measurements at a depth of 22 feet below water surface from a single 80-cubic-inch water gun fired at 2,000 pounds per square inch, Chicago Sanitary Ship Channel, near Lemont, Illinois.

41. Map showing pressure measurements at a depth of 22 feet below water surface from two 80-cubic-inch water guns both fired at 2,000 pounds per square inch, Chicago Sanitary Ship Channel, near Lemont, Illinois.

42. Map showing pressure measurements at a depth of 6 feet below water surface from a single 80-cubic-inch water gun fired at 1,000 pounds per square inch, Chicago Sanitary Ship Channel, near Lemont, Illinois..

43. Map showing pressure measurements at a depth of 6 feet below water surface from two 80-cubic inch water guns both fired at 1,000 pounds per square inch, Chicago Sanitary Ship Channel, near Lemont, Illinois.

44. Map showing pressure measurements at a depth of 14 feet below water surface from a single 80-cubic-inch water gun fired at 1,000 pounds per square inch, Chicago Sanitary Ship Channel, near Lemont, Illinois.

45. Map showing pressure measurements at a depth of 14 feet below water surface from two 80-cubic-inch water guns fired at 1,000 pounds per square inch, Chicago Sanitary Ship Channel, near Lemont, Illinois

46. Map showing pressure measurements at a depth of 22 feet below water surface from a single 80-cubic-inch water gun fired at 1,000 pounds per square inch, Chicago Sanitary Ship Channel, near Lemont, Illinois. 


\section{Figures-Continued}

47. Map showing pressure measurements at a depth of 22 feet below water surface from two 80-cubic-inch water guns both fired at 1,000 pounds per square inch, Chicago Sanitary Ship Channel, near Lemont, Illinois..

48. Graph showing highest velocities from water guns recorded by surface geophones during the 2011 replicate scenario for water guns placed 30 feet from the canal wall and fired at an input pressure of 2,000 pounds per square inch, Chicago Sanitary Ship Channel, near Lemont, Illinois ....

49. Graph showing highest vertical velocities from water guns recorded by surface and downhole geophones during the 2011 replicate scenario for water guns placed 30 feet from the canal wall and fired at an input pressure of 2,000 pounds per square inch, Chicago Sanitary Ship Channel, near Lemont, Illinois ..

50. Graph showing geophone positions along the canal wall relative to water gun center line and velocities recorded at each position from a water gun fired about 40 feet from the wall at a depth of 14 feet below water surface, Chicago Sanitary Ship Channel, near Lemont, Illinois

51. Graphs showing maximum velocities recorded for the 2011 replicate scenario and the double gun grid scenario high pressure trial by the red surface geophone placed 5 feet from the canal wall and borehole geophones placed 5 and 35 feet from the canal wall, Chicago Sanitary Ship Channel, near Lemont, Illinois.

52. Graph showing transverse, longitudinal, and vertical velocities of a single water gun with input pressures of 1,000 and 2,000 pounds per square inch placed 40 feet from the canal wall, as measured by the red surface geophone placed 15 feet downstream of the center line and 5 feet from the canal wall, Chicago Sanitary Ship Channel, near Lemont, Illinois

53. Graph showing transverse, longitudinal, and vertical velocities of a single water gun with input pressure of 1,000 pounds per square inch placed 40 feet from the canal wall and 14 feet below water surface, as measured by surface geophones placed 5 and 15 feet from the canal wall and offset either 5 feet upstream or 5 feet downstream of the water gun, Chicago Sanitary Ship Channel, near Lemont, Illinois....

54. Graphs showing changes in acceleration of pressure wave velocities as water gun distance to the canal wall decreases for the vertical and horizontal components of a double gun firing 40 and 120 feet from the canal wall, Chicago Sanitary Ship Channel, near Lemont, Illinois

55. Graphs showing changes in water pressure as three-dimensional distance from water guns(s) to hydrophone increases when firing one 80-cubic-inch water gun at 1,000 pounds per square inch at Brandon Road study area, Des Plaines River, near Joliet, Illinois; and Lemont study area, Chicago Sanitary Ship Channel, near Lemont, Illinois ....

56. Graphs showing changes in water pressure as three-dimensional distance from water guns to hydrophone increases when firing two 80 -cubic-inch water guns at 1,000 pounds per square inch at Brandon Road study area, Des Plaines River, near Joliet, Illinois; and Lemont study area, Chicago Sanitary Ship Channel, near Lemont, Illinois

57. Graphs showing changes in water pressure as three-dimensional distance from water guns to hydrophone increases when firing two 80 -cubic-inch water guns at 2,000 pounds per square inch at Brandon Road study area, Des Plaines River, near Joliet, Illinois; and Lemont study area, Chicago Sanitary Ship Channel, near Lemont, Illinois .... 


\section{Conversion Factors}

Inch/Pound to International System of Units

\begin{tabular}{lcl}
\hline \multicolumn{1}{c}{ Multiply } & By & \multicolumn{1}{c}{ To obtain } \\
\hline inch (in.) & Length & \\
inch (in.) & 2.54 & centimeter $(\mathrm{cm})$ \\
foot (ft) & 25.4 & millimeter $(\mathrm{mm})$ \\
mile (mi) & 0.3048 & meter $(\mathrm{m})$ \\
\hline & 1.609 & kilometer $(\mathrm{km})$ \\
\hline cubic inch $\left(\right.$ in $\left.^{3}\right)$ & Volume & \\
\hline & 16.39 & cubic centimeter $\left(\mathrm{cm}^{3}\right)$ \\
\hline volts per foot per square seconds & Sensitivity & \\
\multicolumn{1}{c}{$\left[\mathrm{V} /\left(\mathrm{ft} / \mathrm{s}^{2}\right)\right]$} & 0.3048 & volts per meter square seconds \\
\hline & & \\
\hline inch per second (in $/ \mathrm{s})$ & Velocity $/(\mathrm{s})]$ \\
\hline & 0.0254 & meter per second $(\mathrm{m} / \mathrm{s})$ \\
\hline foot per square second $\left(\mathrm{ft} / \mathrm{s}^{2}\right)$ & Acceleration & \\
\hline & 3.280 & meter per square second $\left(\mathrm{m} / \mathrm{s}^{2}\right)$ \\
\hline pound per square inch $\left(\mathrm{lb} / \mathrm{in}^{2}\right)$ & Pressure & \\
cubic foot per minute $\left(\mathrm{ft} / \mathrm{min}^{2}\right)$ & 6.895 & kilopascal $(\mathrm{kPa})$ \\
\hline
\end{tabular}

International System of Units to Inch/Pound

\begin{tabular}{lcc}
\hline \multicolumn{1}{c}{ Multiply } & By & To obtain \\
\hline cubic centimeter $\left(\mathrm{cm}^{3}\right)$ & Volume & \\
\hline & 0.06102 & cubic inch $\left(\mathrm{in}^{3}\right)$ \\
\hline $\begin{array}{l}\text { volts per meter per second } \\
{[\mathrm{V} /(\mathrm{m} / \mathrm{s})]}\end{array}$ & Sensitivity & \\
\hline
\end{tabular}

\section{Datums}

Horizontal coordinate information is referenced to the World Geodetic System 1983 (WGS 83).

Vertical coordinate information is referenced to the North American Vertical Datum of 1988 (NAVD 88). 


\section{Abbreviations}

$\begin{array}{ll}\text { bgs } & \text { below ground surface } \\ \text { bws } & \text { below water surface } \\ \text { CSSC } & \text { Chicago Sanitary and Ship Canal } \\ \text { CAWS } & \text { Chicago Area Waterway System } \\ \text { DR } & \text { Direct Reflect } \\ \text { GNSS } & \text { Global Navigation Satellite Systems } \\ \mathrm{Hz} & \text { hertz } \\ \text { kHz } & \text { kilohertz } \\ \mathrm{NE} / \mathrm{SW} & \text { northeast-southwest } \\ \mathrm{NW} / \mathrm{SE} & \text { northwest-southeast } \\ \text { PVC } & \text { polyvinyl chloride } \\ \text { 3C } & \text { three-component } \\ \text { USACE } & \text { U.S. Army Corps of Engineers } \\ \text { VRS } & \text { Virtual Reference Station }\end{array}$





\title{
Water Pressure and Ground Vibrations Induced by Water Guns near Brandon Road Lock and Dam and Lemont, Illinois
}

\author{
By Ryan F. Adams, Carolyn M. Koebel, and William S. Morrow
}

\section{Abstract}

Multiple geophysical sensors were used to characterize the underwater pressure field and ground vibrations of a seismic water gun and its suitability to deter the movement of Asian carps (particularly the silver [Hypophthalmichthys molitrix] and bighead [Hypophthalmichthys nobilis] carps) while ensuring the integrity of surrounding structures. The sensors used to collect this information were blast-rated hydrophones, surface- and borehole-mounted geophones, and fixed accelerometers.

Results from two separate studies are discussed in this report. The Brandon Road study took place in May 2014, in the Des Plaines River, in a concrete-walled channel downstream of the Brandon Road Lock and Dam near Joliet, Illinois. The Lemont study took place in June 2014, in a segment of the dolomite setblock-lined Chicago Sanitary and Ship Canal near Lemont, Illinois.

Two criteria were evaluated to assess the potential deterrence to carp migration, and to minimize the expected effect on nearby structures from discharge of the seismic water gun. The first criterion was a 5-pound-per-square-inch $\left(\mathrm{lb} / \mathrm{in}^{2}\right)$ limit for dynamic underwater pressure variations. The second criterion was a maximum velocity and acceleration disturbance of 0.75 inch per second (in/s) for sensitive machinery (such as the lock gates and pumps) and $2.0 \mathrm{in} / \mathrm{s}$ adjacent to canal walls, respectively. The criteria were based on previous studies of fish responses to dynamic pressure variations, and effects of vibrations on the structural integrity of concrete walls.

The Brandon Road study evaluated the magnitude and extent of the pressure field created by two water gun configurations in the concrete-walled channel downstream of the lock where channel depths ranged from 11 to 14 feet (ft). Data from a single 80-cubic-inch (in ${ }^{3}$ ) water gun set at $6 \mathrm{ft}$ below water surface (bws) produced a roughly cylindrical 5-lb/in ${ }^{2}$ pressure field $20 \mathrm{ft}$ in radius, oriented vertically, with the radius decreasing to less than $15 \mathrm{ft}$ at the water surface. A combination of two 80 -in ${ }^{3}$ water guns set at 6 and $8 \mathrm{ft}$, respectively, produced a similarly shaped $5 \mathrm{lb} / \mathrm{in}^{2}$ pressure field $30 \mathrm{ft}$ in radius. Neither of the water gun configurations exceeded the given threshold of $5 \mathrm{lb} / \mathrm{in}^{2}$ above the static pressure along the walls of the canal at the $700 \mathrm{lb} / \mathrm{in}^{2}$ water gun input pressure. Velocity and acceleration data were collected simultaneously with the underwater pressure data to understand the response of adjacent canal walls to the water gun firings. Maximum velocity and acceleration were $0.239 \mathrm{in} / \mathrm{s}$ and 0.0188 feet per second squared $\left(\mathrm{ft} / \mathrm{s}^{2}\right)$, respectively.

The Lemont study replicated and expanded upon work done in 2011. The pressure field created by the water gun was evaluated in a deeper environment (about $25 \mathrm{ft}$ of water depth) than that of the Brandon Road study. To replicate the 2011 study, data were collected with the same water gun placements and input pressure, but static underwater pressure monitoring was added. Two 80 -in ${ }^{3}$ water guns were suspended below a platform at depths of 4 and $14 \mathrm{ft}$ bws. Pressure was lower when the gun suspended at $4 \mathrm{ft}$ bws was fired as compared to firing the single gun suspended at $14 \mathrm{ft}$ bws. Firing both guns simultaneously produced similar pressures to the single gun suspended at $14 \mathrm{ft}$ bws. Data were collected to assess the pressure field produced by two 80 -in ${ }^{3}$ water guns separated by $80 \mathrm{ft}$ and suspended at a depth of $14 \mathrm{ft}$ bws. The spatial extent of the $5-1 \mathrm{~b} / \mathrm{in}^{2}$ threshold varied substantially with gun input air pressure. Firing the water gun with an air pressure of 2,000 lb/in ${ }^{2}$ generated a pressure field greater than the threshold at all but one location in the measured region. Additionally, the water gun with an air pressure of 1,000 lb/in ${ }^{2}$ did not reach the threshold anywhere in the measured region. Maximum velocity and acceleration were $0.304 \mathrm{in} / \mathrm{s}$ and $0.015 \mathrm{ft} / \mathrm{s}^{2}$, respectively. 


\section{Introduction}

The construction of the Chicago Sanitary and Ship Canal (CSSC) and the encompassing Chicago Area Waterway System (CAWS) in the early 20th century created a 28-mi waterway between Lake Michigan and the Illinois River, artificially connecting the Great Lakes Basin with the Mississippi River Basin. This waterway enabled the movement of aquatic species between the Illinois River and Lake Michigan. The Asian carps, particularly the silver (Hypophthalmichthys molitrix) and bighead (H. nobilis) carps, are invasive aquatic species, with a large sustaining population in the Illinois River (Adams and Morrow, 2015). Currently (2016), the electric dispersal barriers near Romeoville, Illinois (U.S. Army Corps of Engineers, 2011) deter fish migration between the Mississippi River Basin and the Great Lakes Basin. Research is underway on additional measures to deter the movement of these fish.

The U.S. Geological Survey (USGS), in cooperation with the U.S. Environmental Protection Agency, Great Lakes Restoration Initiative, is evaluating the underwater pressure field and ground vibrations produced from the firing of a seismic water gun (fig. 1) and its potential effectiveness of producing a pressure barrier to prevent or direct the movement of the Asian carps while ensuring the integrity of surrounding structures (Turnpenny and Nedwell, 1994; Keevin and Hempen, 1997; Wardle and others, 2001; Lokkeborg and others, 2012; Gross and others, 2013). The water gun uses large amounts of high-pressure air to rapidly eject a volume of water from the water gun chamber. The ejection of the water creates a vacuum that is rapidly filled by the collapse of water back into the empty space, creating an implosion and resulting pressure wave.

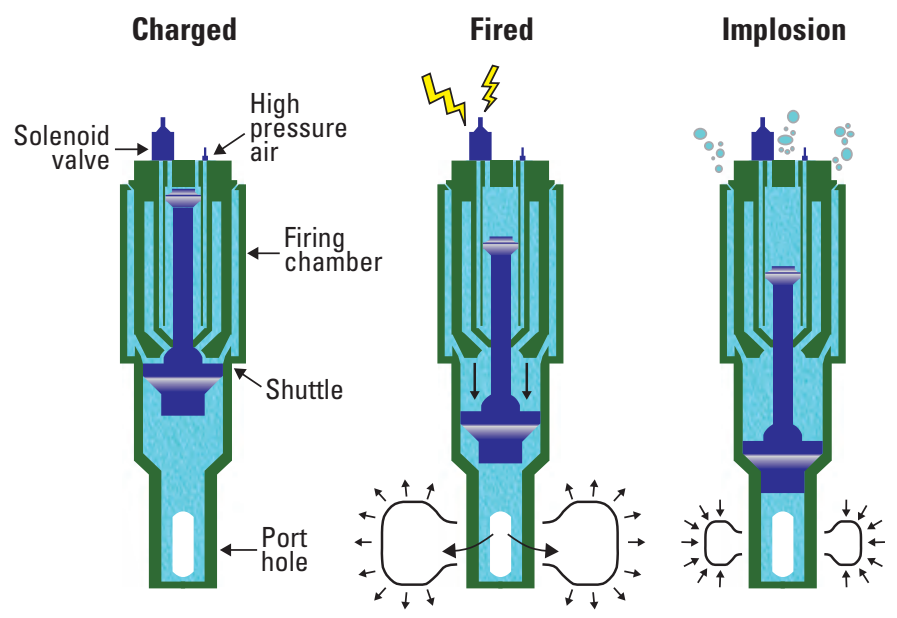

Figure 1. Water gun firing schematic (diagram redrafted from Layhee and others, 2013).

\section{Purpose and Scope}

The purpose of this report is to define the magnitude and extent of the pressure field created by $80-\mathrm{in}^{3}$ water guns fired at two test areas at various depths and gun pressures in the Des Plaines River and the CSSC. The seismic acceleration and velocity response of the walls at the two areas from water gun firing were recorded to determine safe water gun input pressure and distance from surrounding structures. The two test areas are the channel downstream of the Brandon Road Lock and Dam at Joliet, Illinois, and an open channel area along the CSSC upstream of Lemont, Illinois. At the Lemont test area, data also were collected to augment previous seismic data collected in September of 2011 (Morrow and others, 2015).

The data collected and analyzed for this report are available in comma-separated values format in Adams and others (2017).

\section{Brandon Road Test Area Description}

The Brandon Road Lock and Dam is located near Joliet, Illinois. The lock, which is $600 \mathrm{feet}(\mathrm{ft})$ long and $110 \mathrm{ft}$ wide, helps boats navigate a 34-ft drop in water surface elevation between the Lake Michigan and Illinois River sides of the structure (U.S. Army Corps of Engineers, 2015). The defined, concrete-walled channel downstream of the lock is $110 \mathrm{ft}$ wide and about $285 \mathrm{ft}$ long, with a wider channel farther downstream about $250 \mathrm{ft}$ wide and 1,700 ft long (fig. 2). The mid-channel depth is about $14 \mathrm{ft}$ bws, with depths varying across the channel from 11 to $14 \mathrm{ft}$ bws. The surrounding bedrock is dolomite.

The water gun, or guns, were set approximately $250 \mathrm{ft}$ downstream of the downstream lock gates and $40 \mathrm{ft}$ upstream of the end of the south canal wall (also referred to as the testing wall), and were secured mid-channel (fig. 2). The testing was done in a two-wall section of the channel because the pressure wave from the gun is influenced by the confined space.

\section{Lemont Test Area Description}

The Lemont test area in the CSSC was selected based on the topographical and geological similarity of the site to the electric dispersal barrier site near Romeoville, Illinois. The open CSSC channel also represents typical channel geometry along the CSSC. Dolomite or dolomite setblock composes the canal walls. The width of the canal at the testing point was about $167 \mathrm{ft}$, with a canal depth of about $25 \mathrm{ft}$ extending approximately to the canal walls. The location is about $5 \mathrm{mi}$ upstream of the electric dispersal barrier at the end of a roadway and cul-de-sac off the Illinois and Michigan Canal bike path on Cook and DuPage County Forest Preserve land (fig. 3). 


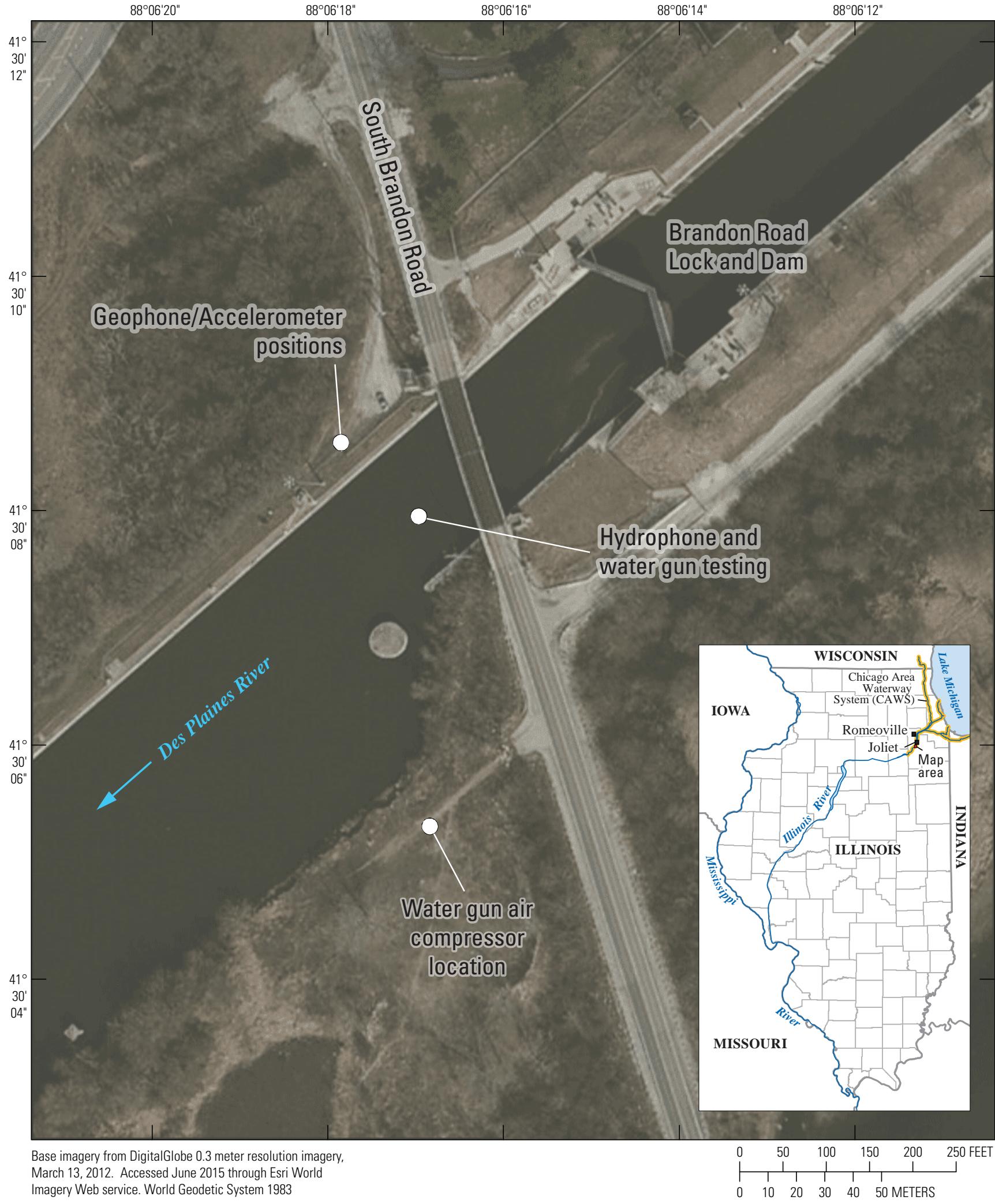

Figure 2. Location of study area and major sensor groups (hydrophones, geophones, and accelerometers), Des Plaines River, near Joliet, Illinois. 


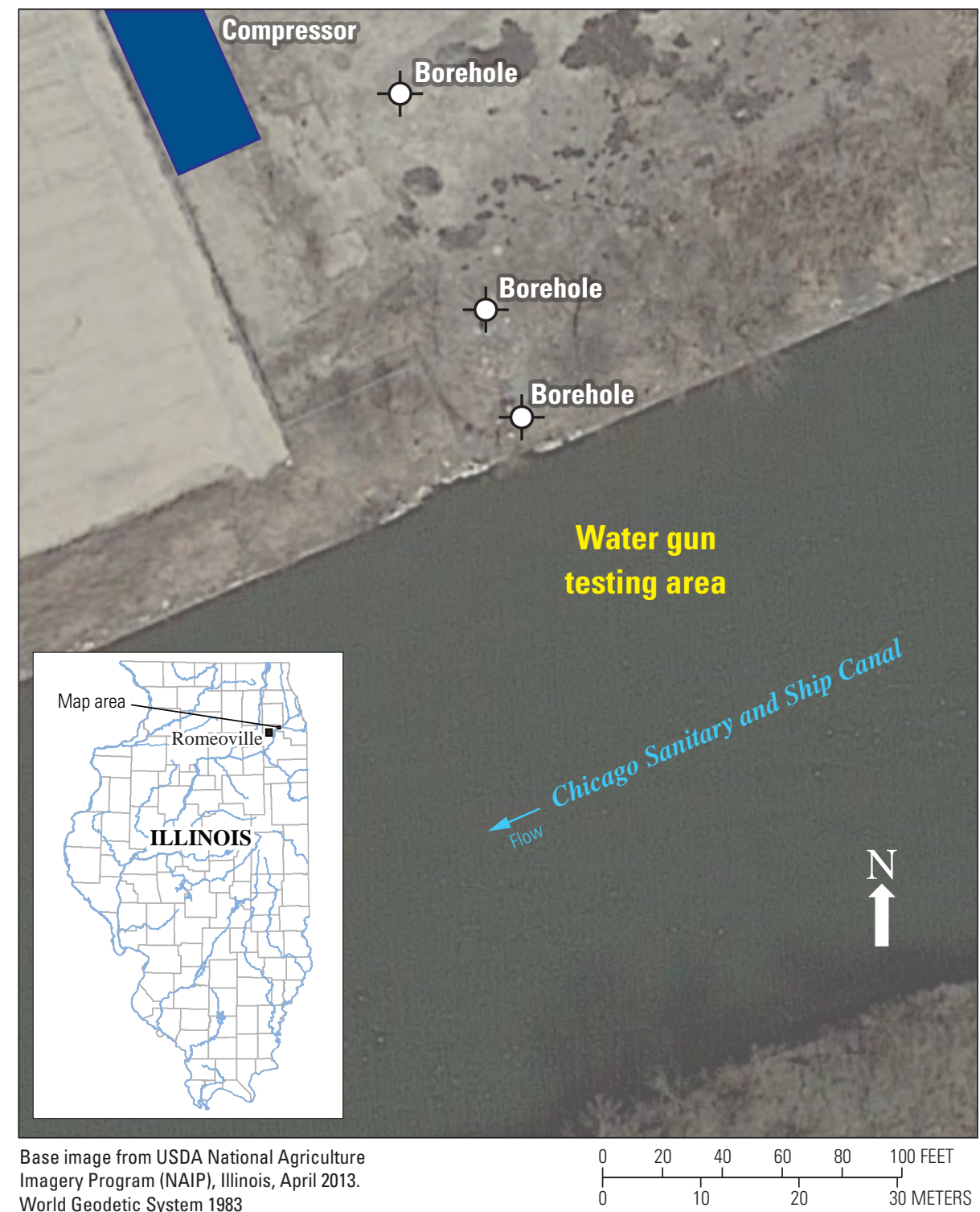

Figure 3. Location of Lemont water gun test and data collection areas, Chicago Sanitary Ship Channel, near Lemont, Illinois.

\section{Methods}

Seismic data were acquired during May 19-22, 2014, at the Brandon Road test area, and during June 2-5, 2014, at the Lemont test area.

Underwater pressure data were collected using blast hydrophones and underwater blast sensors. Pressure was monitored to determine areal coverage as well as depth, and to determine if the 5-lb/in ${ }^{2}$ threshold, or greater pressure, was created at wall structures. Fish behavior data collected during pond experiments at the U.S. Geological Survey Upper Midwest Environmental Sciences Center indicated that a pressure near $4 \mathrm{lb} / \mathrm{in}^{2}$ was sufficient to affect the movement of Asian carps (Romine and others, 2015). Additionally, 5 lb/in ${ }^{2}$ greater than the static water pressure was given as the pressure limit in the use of water guns near sensitive structures (Fred Joers, U.S. Army Corp of Engineers, oral commun., 2013). In recognition of both these values, $5 \mathrm{lb} / \mathrm{in}^{2}$ was used as a benchmark for the evaluation of water gun pressure fields. These pressure data were used to create pressure maps at various depths for each scenario tested.

Land data consisting of velocity and acceleration measurements were collected using geophones and accelerometers for transverse, longitudinal, and vertical wave propagation. Velocities and accelerations were collected at and away from the canal wall relative to varying distances of the water gun or guns from the wall. Velocity data were monitored for exceedances of the U.S. Bureau of Mines standard of 
2 inches per second (in/s) for adjacent structures (Siskind and others, 1980) —in this case, the adjacent canal walls —and $0.75 \mathrm{in} / \mathrm{s}$ (velocity threshold for sensitive machinery areas) as requested by the U.S. Army Corps of Engineers (Fred Joers, U.S. Army Corps of Engineers, written commun., 2013). For this report, the lower velocity level of $0.75 \mathrm{in} / \mathrm{s}$ is referenced for comparisons.

\section{Equipment}

One or two 80 -in ${ }^{3}\left(1,310\right.$-cubic-centimeter $\left.\left[\mathrm{cm}^{3}\right]\right)$ water guns were deployed during these studies. The water guns were suspended from anchored $6 \times 6 \mathrm{ft}$ floating platforms. The firing of each water gun was controlled by a HotShot ${ }^{\circledR}$ controller (Real Time Systems, Fredericksburg, Texas) tethered to a laptop computer. High-pressure air was supplied to each gun by a high-pressure, high-volume air compressor (rated at 5,000 lb/in ${ }^{2}$ and 81 standard cubic feet per minute [ft $\left.\left.\mathrm{ft}^{3} / \mathrm{min}\right]\right)$.

Hydrophones are piezoelectric sensors used to determine the increase in pressure from the water guns. The effect of the blast front moving through the water on a quartz crystal in the blast hydrophone produces an electrical voltage in proportion to the pressure increase. The blast hydrophone records only the change in pressure as a result of the water gun firing, not the static pressure. These hydrophone sensors have a sensitivity of $0.0237 \mathrm{lb} / \mathrm{in}^{2}$. They were sampled at a rate of 8,000-32,000 hertz (Hz) (8-32 kilohertz [kHz]) by a seismograph. These sensors have a maximum pressure threshold of $47 \mathrm{lb} / \mathrm{in}^{2}$. The water guns used in these studies generate this pressure threshold out to a maximum distance of about 15 horizontal feet from the water gun. To avoid damage to the sensors, the sensors always were placed at least $15 \mathrm{ft}$ away from the water guns; the area inside this 30 -ft-diameter circle is referred to as the hydrophone exclusion zone in figures and text that follow.
Geophones are mechanical sensors that record the magnitude of ground motion using calibrated weights and springs. The metal weight moving within a coil of wire produces a voltage equivalent to the motion of the geophone. This voltage is transmitted through wires to the seismograph.

Three-component (3C) surface geophones (R.T. Clark, Oklahoma City, Oklahoma)—with a frequency of $10 \mathrm{~Hz}$, coil resistance of $395 \mathrm{ohms}$, and sensitivity of 27.5 volts per meter per second $[\mathrm{V} /(\mathrm{m} / \mathrm{s})]$ — were used throughout the survey and were connected to a seismograph. The seismograph sampled these geophones at a rate of 8,000 samples per second (sps) for a period of 8 seconds (s). Additional 3C surface geophones manufactured by Instantel ${ }^{\circledR}$ (Ogdensburg, New York) were used to supplement the R.T. Clark geophones. The Instantel ${ }^{\circledR}$ geophones were calibrated by the International Society of Explosive Engineers 1 month prior to the start of field work and were used as quality assurance for the R.T. Clark geophones. These geophones have a frequency of $2 \mathrm{~Hz}$ and a resolution of $0.00031 \mathrm{in} / \mathrm{s}$. They were sampled at a rate of $16 \mathrm{kHz}$ by a seismograph.

Average maximum velocities are compared in figure 4, with 1 standard deviation error, for the near and far Instantel (dark and light gray, respectively) and the near and far R.T. Clark (red and blue, respectively) geophones for a 2,000 lb/in ${ }^{2}$ shot located $50 \mathrm{ft}$ from the canal wall at Brandon Road. Velocities for the R.T. Clark and calibrated Instantel ${ }^{\circledR}$ surface geophones at the same location generally were within $0.02 \mathrm{in} / \mathrm{s}$ of each other, or about 3 percent of the $0.75 \mathrm{in} / \mathrm{s}$ limit for sensitive structures. At a maximum, the difference between the two readings was $0.04 \mathrm{in} / \mathrm{s}$ and the average standard deviation was about $0.01 \mathrm{in} / \mathrm{s}$. Because these geophones pairs produced similar results and the Instantel geophones have a flat response over the frequencies of $2-250 \mathrm{~Hz}$, a flat conversion was selected to convert millivolts $(\mathrm{mV})$ to inches per second (in/s) for the R.T. Clark geophones. Using the geophone sensitivity of $27.5[\mathrm{~V} /(\mathrm{m} / \mathrm{s})], 1 \mathrm{mV}$ is equivalent to $0.00143 \mathrm{in} / \mathrm{s}$ (It is noteworthy that the value of $0.00143 \mathrm{in} / \mathrm{s}$ here differs from $0.00031 \mathrm{in} / \mathrm{s}$ for $27.5[\mathrm{~V} /(\mathrm{m} / \mathrm{s})]$ in the previous paragraph).

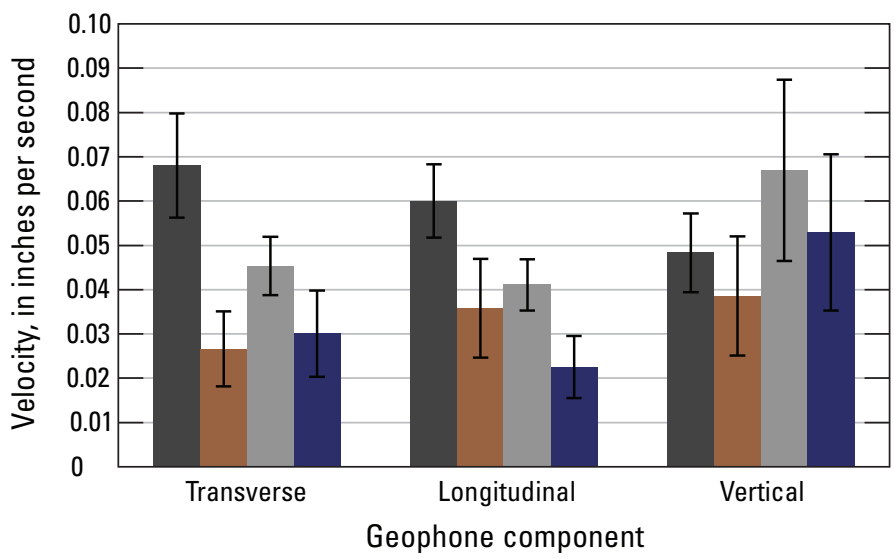

EXPLANATION

Near dark gray geophone

Near red geophone

Far light gray geophone

Far blue geophone
Figure 4. Velocities of near (6 feet from wall, dark gray) and far (16 feet from wall, light gray) Instante ${ }^{\circledR}$ and near ( 6 feet from wall, red) and far (16 feet from wall, blue) R.T. Clark surface geophone pairs from a 2,000-pound-per-square-inch shot located 50 feet from canal wall. Velocities are plotted with 1 standard deviation error. 
Downhole 3C land geophones manufactured by R.T. Clark with a frequency of $10 \mathrm{~Hz}$, coil resistance of $395 \mathrm{ohms}$, and a sensitivity of $27.5[\mathrm{~V} /(\mathrm{m} / \mathrm{s})]$ were used in the three boreholes and the 3 -in. polyvinyl chloride (PVC) pipe affixed to the side of the canal wall at Lemont. The geophones were held in place at the desired elevation by attached steel springs that were manually released, causing the springs to expand and seat firmly against the borehole. The seismograph sampled these geophones at a rate of 8,000 sps for a period of $8 \mathrm{~s}$.

Acceleration was recorded using two, one-component accelerometers. These sensors were sampled at 8,00032,000 sps by a data-acquisition system. These sensors have a sensitivity of 0.309 volts per foot per square seconds $\left[\mathrm{V} /\left(\mathrm{ft} / \mathrm{s}^{2}\right)\right]$.

\section{Brandon Road Study}

The Brandon Road study consisted of four water-gun scenarios. The scenarios had similar goals - to determine the maximum safe gun input pressure and distance from concrete canal walls for a single water gun or a pair of water guns such that the ground velocity does not exceed $0.75 \mathrm{in} / \mathrm{s}$ and the pressure on the canal walls does not exceed $5 \mathrm{lb} / \mathrm{in}^{2}$. These scenarios were as follows:

1. Varying gun distance. One $80-i^{3}$ water gun was placed at multiple distances from the canal wall and fired at increasing pressures to determine the safe operating conditions.

2. Single gun radial. One 80 -in ${ }^{3}$ water gun was placed in the center of the channel ( $55 \mathrm{ft}$ from the right bank wall; right or left is from the perspective of an observer looking downstream) and hydrophone data were recorded radially to understand the extent and azimuthal variability of the pressure field.

3. Static boom high pressure tests. A single $80-\mathrm{in}^{3}$ and two 80 -in ${ }^{3}$ water guns were placed in the center of the channel ( $55 \mathrm{ft}$ from the right bank wall) and fired at high input pressures $\left(1,000-2,000 \mathrm{lb} / \mathrm{in}^{2}\right)$ to evaluate the effects on pressure and velocity.

4. Double gun radial. Two $80-\mathrm{in}^{3}$ water guns were suspended at two different depths, fired simultaneously, and hydrophone data were measured radially to evaluate the interactions of multiple pressure fields.

The locations of the water guns, hydrophones, and geophones were determined using a laser transit. A temporary benchmark and reference points were established using a Trimble ${ }^{\circledR}$ R8 Global Navigation Satellite Systems (GNSS) receiver, and positions were corrected in real-time using the Trimble Virtual Reference Station (VRS) Now ${ }^{\circledR}$ service. The temporary bench mark and reference points were referenced to a horizontal datum of World Geodetic System 1983 (WGS 83) and vertical datum of North American Vertical Datum of 1988 (NAVD 88). The Trimble 5600 Direct Reflect (DR) $200+$ Total Station was positioned at the established benchmark and the survey was corrected for position, rotation, and scale by shooting a prism at each reference point measuring its distance. With the Total Station survey setup complete, the direct reflex method (David Fazio, U.S. Geological Survey, written commun., 2017) was used to determine the positions of the water guns, hydrophones, and geophones. Those positions were recorded in the Trimble Survey Controller. Georeferencing targets located on the boom and a central point on the water gun platform were surveyed using direct reflex to determine the position of the hydrophone boom.

Hydrophones were moved to various positions around the water guns to define the extent of the resulting pressure field. For most setups, the water guns were secured in a fixed position and depth and fired at a constant pressure. The hydrophones were suspended from a 30 -ft-long rectangular PVC boom (figs. 5-8) that pivoted from the water gun location. Four groups of six sensors each (24 total) were suspended beneath this boom at depths of $0,2,4,6,8$, and $9 \mathrm{ft}$, with an even horizontal spacing of $10 \mathrm{ft}$. The boom was moved sequentially in the water surrounding the water gun to collect pressure data. Five water gun shots were taken at each boom position. For each shot, the maximum value was recorded (data are logged every $0.0000625 \mathrm{~s}$ for $3 \mathrm{~s}$ following firing). The arithmetic mean of the five maximum values recorded at each hydrophone position and the processed location data were used to create the pressure map figures.

Seismic velocity data were collected using geophones and accelerometers. The locations of the water gun or guns remained fixed for most scenarios. Multiple geophone configurations were used for the water-gun scenarios to obtain detailed coverage of the velocity response of the area behind the canal wall. Accelerometer locations were fixed.

Two single-component accelerometers were attached to an aluminum block mounted on top of the concrete wall (figs. 5-8). This block was placed about 3 in. from the edge of the wall and directly on the center line, the line created between the water gun and the hydrophone boom when the boom was directly perpendicular to the testing wall. One accelerometer was mounted vertically on top of the rectangular block and the other was mounted horizontally on the side facing the river and water gun. For the vertical unit, a positive deflection indicated upward movement toward the sky and a negative deflection indicated downward movement toward the ground. For the horizontal unit, a positive deflection indicated movement of the wall outwards toward the river and a negative deflection indicated movement inward toward the geophone array. The accelerometers remained fixed for the duration of the experiment.

Six R.T. Clark and two Instantel ${ }^{\circledR} 3 \mathrm{C}$ geophones were used to record seismic velocities. The exact positions of the geophones were determined by using laser transit, and positions were referenced to the edge of the wall and the center line. Each of the otherwise identical R.T. Clark geophones was assigned a color to identify it for discussion in this report, and the Instantel ${ }^{\circledR}$ geophones were fixed in place and referenced as "Near" and "Far" from the edge of the concrete wall (figs. 5-8). 


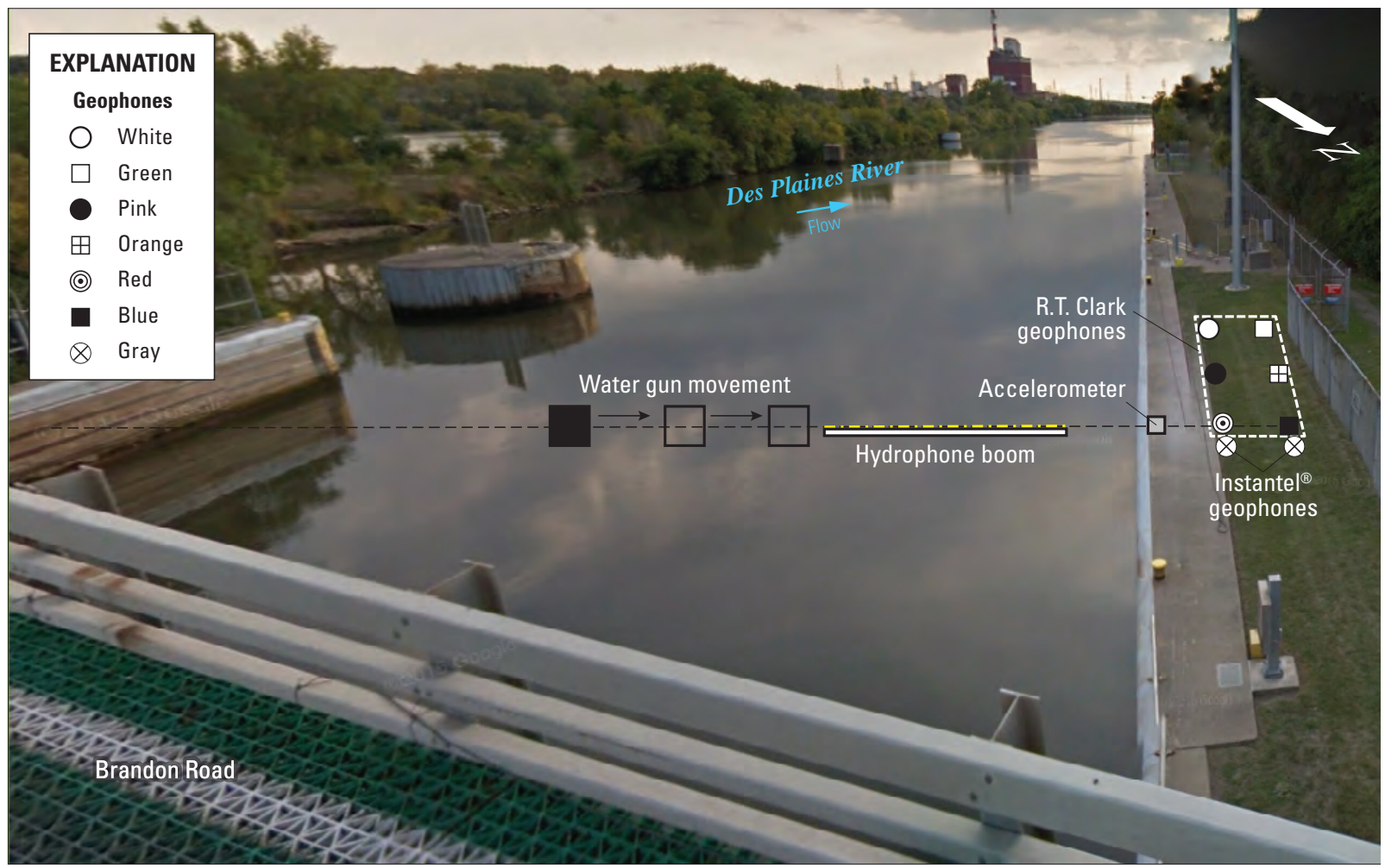

Base image from Google Maps Street View, October 2013,

S Brandon Rd, Joliet, Illinois. View accessed January 2016

Figure 5. Water gun, geophone, and accelerometer positions for varying gun distance scenario, Brandon Road study, Des Plaines River, near Joliet, Illinois.

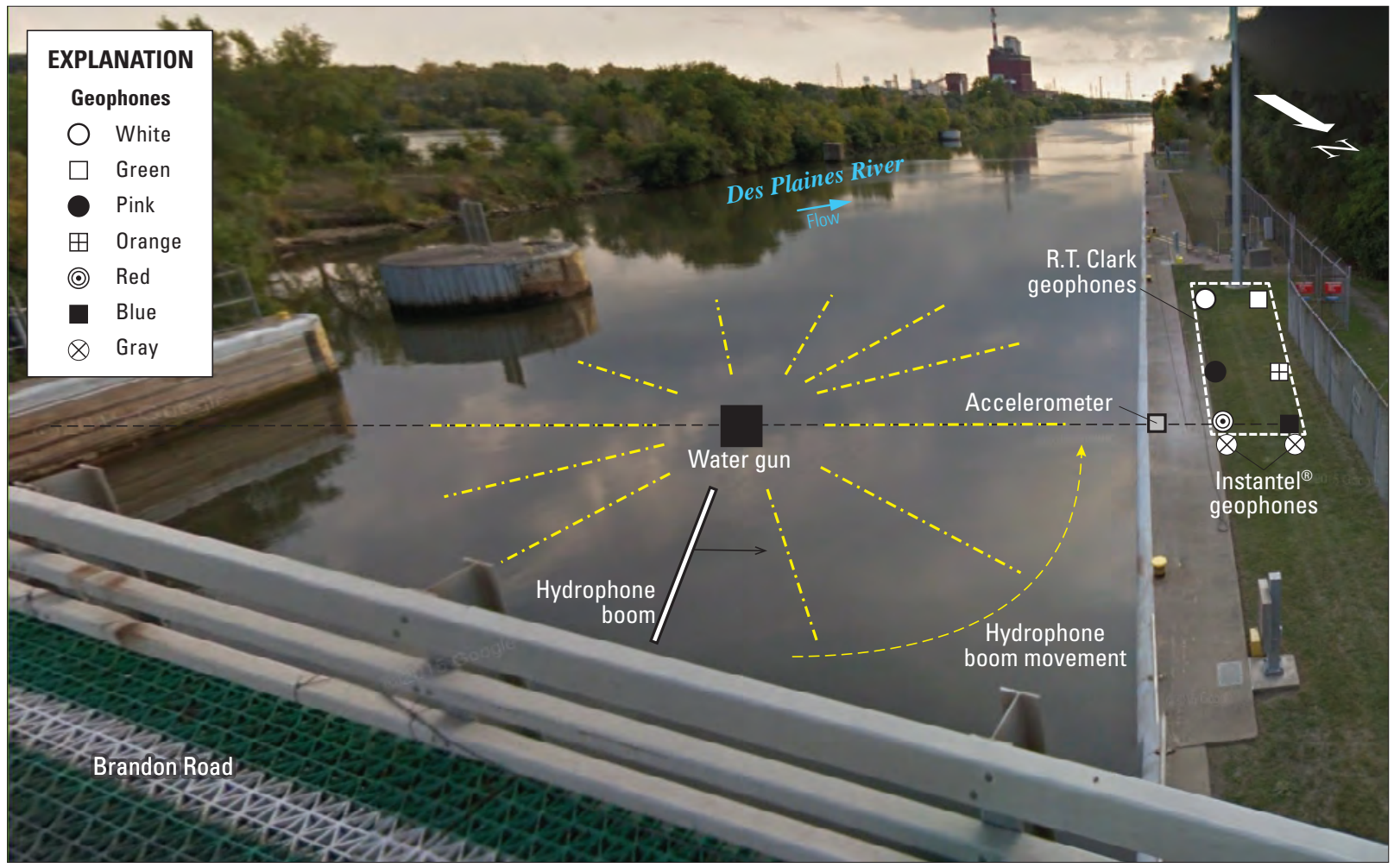

Base image from Google Maps Street View, October 2013,

S Brandon Rd, Joliet, Illinois. View accessed January 2016

Figure 6. Water gun, geophone, and accelerometer positions for single gun radial scenario, Brandon Road study, Des Plaines River, near Joliet, Illinois. 


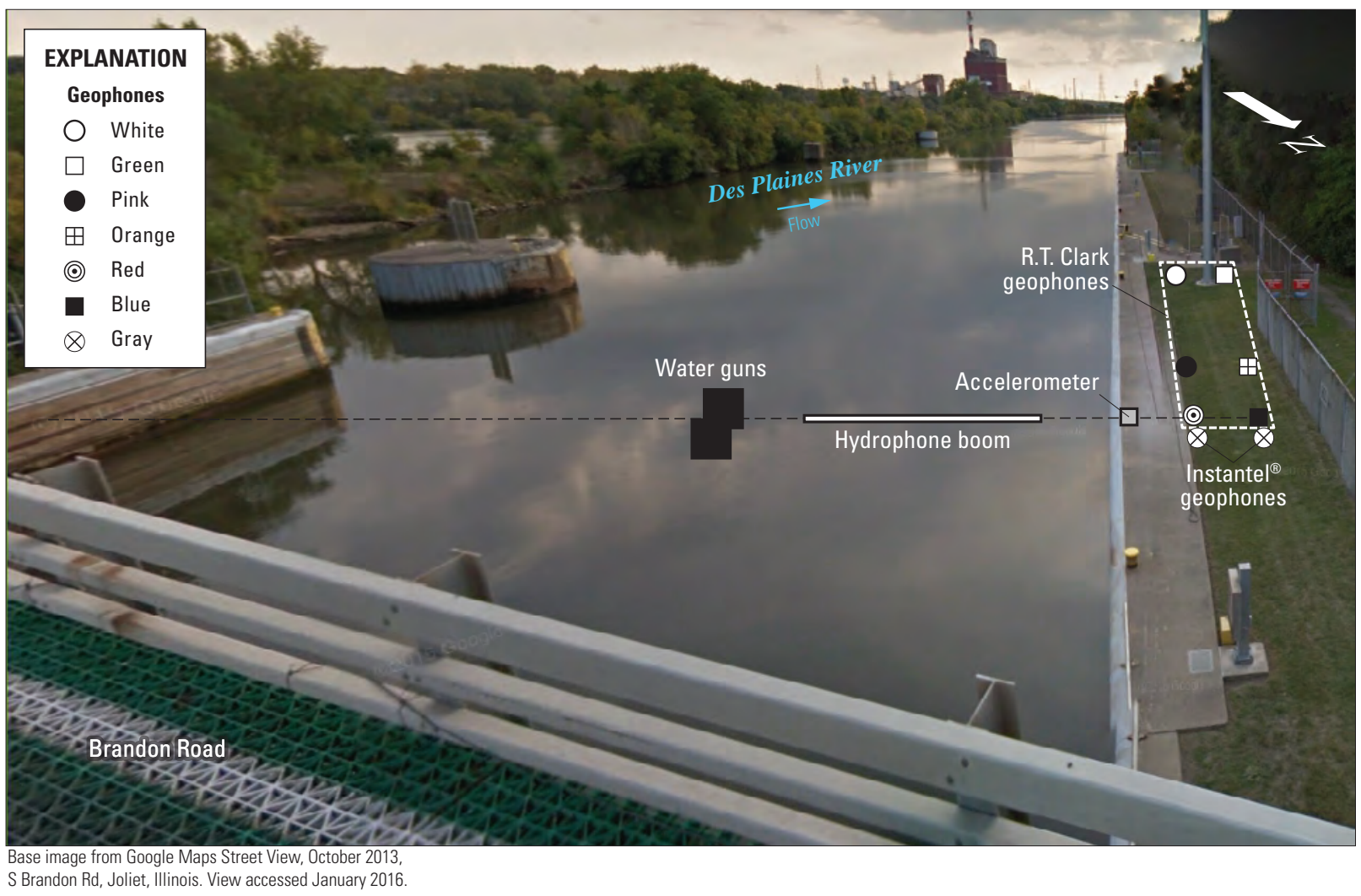

Figure 7. Water gun, geophone, and accelerometer positions for static boom high pressure scenario, Brandon Road study, Des Plaines River, near Joliet, Illinois.

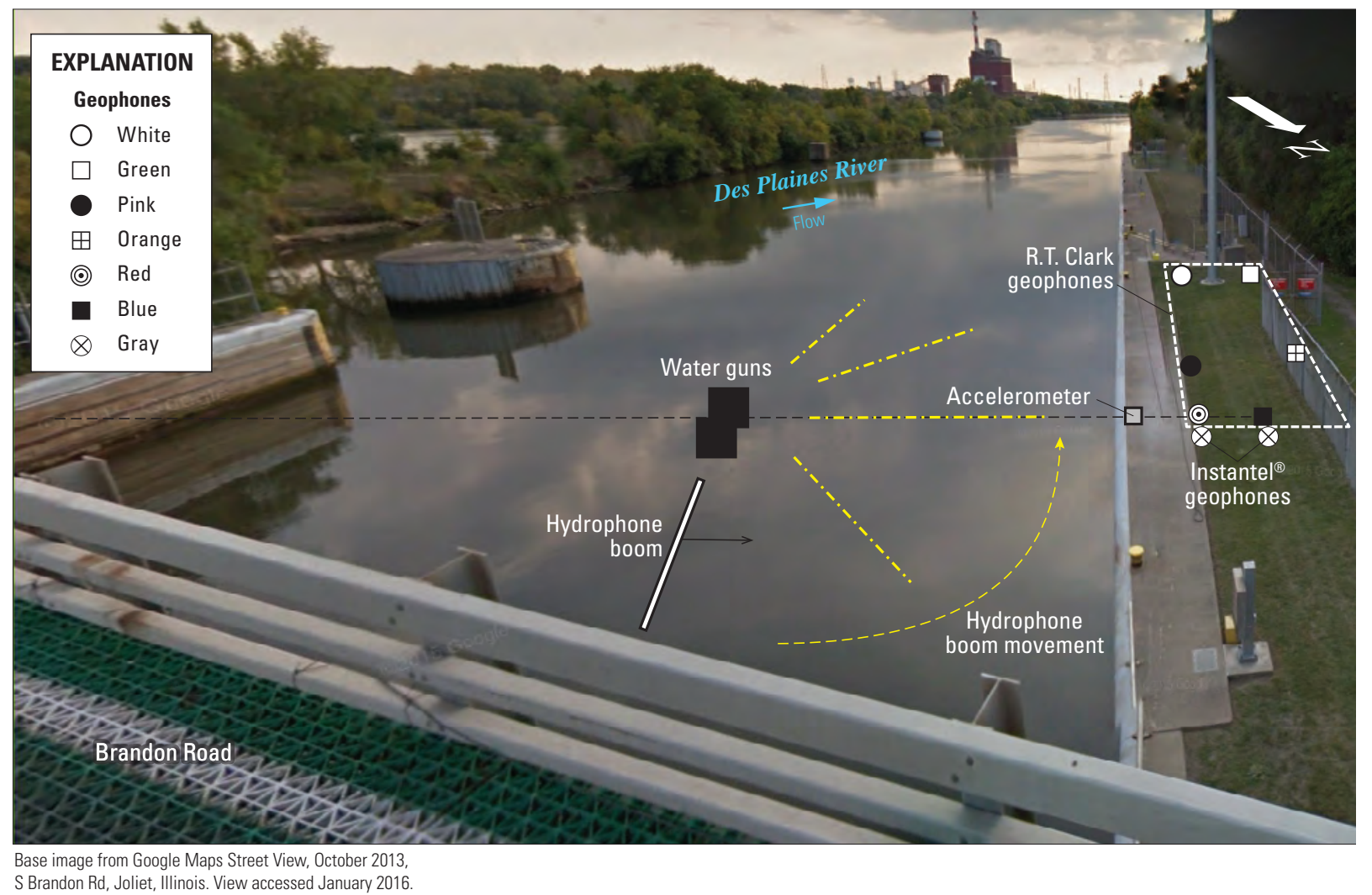

Figure 8. Water gun, geophone, and accelerometer positions for double gun radial scenario, Brandon Road study, Des Plaines River, near Joliet, Illinois. 


\section{Varying Gun Distance Scenario}

One 80 -in ${ }^{3}$ water gun was placed in the center of the channel (initially $55 \mathrm{ft}$ from the wall) and then was moved closer in 5-ft increments (fig. 5). The gun ports were aligned approximately northwest-southeast (NW/SE) such that they were perpendicular to the walls of the channel and positioned at a depth of $6 \mathrm{ft}$ bws. The single water gun was fired at increasing input pressures, beginning at $500 \mathrm{lb} / \mathrm{in}^{2}$ (the operational minimum) and proceeding until the 5-lb/in ${ }^{2}$ pressure threshold at the wall was reached. The input pressure ranged from 750 to $500 \mathrm{lb} / \mathrm{in}^{2}$ based on the distance from the wall. Once the $5 \mathrm{lb} / \mathrm{in}^{2}$ pressure limit was reached at a testing location, the water gun was moved $5 \mathrm{ft}$ closer to the testing wall and testing resumed at the minimum pressure.

The hydrophone boom was positioned approximately NW/SE such that it was perpendicular to the walls of the channel and located $17.5 \mathrm{ft}$ from the edge of the water gun platform and $8 \mathrm{ft}$ from the edge of the testing wall. For this setup, the two hydrophone groups in the center of the boom (at 27.5 and $37.5 \mathrm{ft}$ from the gun, respectively) were recording data. A separate group of hydrophones were suspended directly from the wall using a spacer to achieve a distance of $1 \mathrm{ft}$ from the wall. The hydrophone boom remained fixed relative to the wall throughout the scenario.

\section{Single Gun Radial Scenario}

One 80 -in ${ }^{3}$ water gun was placed in the center of the channel (55 ft from the wall). The ports were aligned roughly NW/SE such that they were perpendicular to the walls of the channel and were positioned at a depth of $6 \mathrm{ft}$ bws. The single water gun was fired at $700 \mathrm{lb} / \mathrm{in}^{2}$ based on the results from the varying gun distance scenario.

The hydrophone boom initially was positioned with the first hydrophone group $15 \mathrm{ft}$ from the edge of the water gun platform and roughly aligned NW/SE such that the boom was directly perpendicular to the testing wall. From this initial position, the hydrophone boom was swung around the water gun at about 30-degree increments (fig. 6).

\section{Static Boom High Pressure Scenario}

One 80 -in ${ }^{3}$ water gun was placed in the center of the channel (55 ft from the wall). The ports were aligned roughly NW/SE such that they were perpendicular to the walls of the channel and were positioned at a depth of $6 \mathrm{ft}$. The single water gun was fired at increasing pressures beginning at $500 \mathrm{lb} / \mathrm{in}^{2}$ (the operational minimum) and increasing to as much as $2,000 \mathrm{lb} / \mathrm{in}^{2}$ (the operational maximum). Once the water gun was pressurized to $1,000 \mathrm{lb} / \mathrm{in}^{2}$, the number of shots for each pressure was reduced in accordance with U.S. Army Corps of Engineers (USACE) personnel on site monitoring the wall pressure and velocity readings. Instead of the standard five shots, the number of shots for each pressure greater than
1,000 lb/in² ranged from 2 to 4 (fig. 7) to reduce the possibility of negative effects on the integrity of the wall.

After the highest pressure was completed with one gun, a second water gun was placed next to the original water gun. These two, $80-\mathrm{in}^{3}$ water guns were located in the center of the channel (55 ft from the wall). The two water gun platforms were fastened together and the water guns were suspended below them with a horizontal offset of about $6 \mathrm{ft}$ from one gun to another. The ports of the first gun were aligned approximately NW/SE, perpendicular to the walls, at a depth of $6 \mathrm{ft}$ bws; the second gun was placed orthogonally to the first but with the gun ports aligned northeast-southwest (NE/SW), parallel to the walls, at a depth of $8 \mathrm{ft}$ bws.

The two guns were fired in a staggered fashion, with the gun $8 \mathrm{ft}$ bws being fired first and then both guns being fired together. Data were collected for both the single and double water gun shots, with water gun pressures starting at $500 \mathrm{lb} / \mathrm{in}^{2}$ (the operational minimum) and increasing to as much as 2,000 lb/in ${ }^{2}$ (the operational maximum). As pressures increased to more than $1,000 \mathrm{lb} / \mathrm{in}^{2}$, the number of shots at a given pressure was decreased to between 2 and 4 .

\section{Double Gun Radial Scenario}

This scenario was set up identically to the static boom high pressure scenario. Two, 80 -in ${ }^{3}$ water guns were placed in the center of the channel with a horizontal offset of about $6 \mathrm{ft}$ from one gun to another. Gun ports aligned roughly NW/SE perpendicular to the walls at a depth of $6 \mathrm{ft}$ bws; the other gun was placed orthogonally with the gun ports aligned NE/SW parallel to the walls at a depth of $8 \mathrm{ft}$ bws.

The water gun or guns were fired at $1,000 \mathrm{lb} / \mathrm{in}^{2}$ in a staggered fashion, with 5 shots collected on the 8-ft-deep gun alone and then 5 shots collected on both guns fired together. Once the data were collected, the boom was rotated 45 degrees and data were collected again. Data coverage of this area was obtained, consisting of the semicircle located 180 degrees from of the northwestern side of the channel facing the testing wall (fig. 8).

\section{Lemont Study}

The CSSC upstream of Lemont is about $160 \mathrm{ft}$ wide and $25 \mathrm{ft}$ deep, making this test area greater in depth and width than the Brandon Road test area. Additionally, the three previously (2011) installed boreholes at Lemont allowed monitoring at depth of the land mass affected by the seismic energy created by the water guns, as well as its surface. Two scenarios were tested in the data collection at Lemont:

1. 2011 replicate. Two 80 -in ${ }^{3}$ water guns were set up in the CSSC to recreate the testing done on the same site in 2011 (Morrow and others, 2015), as well as to collect additional data at different water gun depths. 
2. Double gun grid. Two 80 -in ${ }^{3}$ water guns were set up spaced apart across the channel and at equal depths in the CSSC to evaluate the extent and magnitude of the pressure field created. This scenario was repeated twice-once at 2,000 lb/in (high pressure), and once at $1,000 \mathrm{lb} / \mathrm{in}^{2}$ (low pressure).

Because of the approximate 25 -ft depth of the CSSC, the hydrophones were deployed differently during Lemont testing than they were during Brandon Road testing. Hydrophones were suspended on chains hanging from a large buoy at the water surface. Two strings of hydrophones were used and kept at fixed $10-\mathrm{ft}$ spacing.

The locations of the water guns, hydrophones, and geophones were determined using a laser transit. A temporary benchmark and reference points were established using a Trimble ${ }^{\circledR}$ R8 GNSS receiver, and positions were corrected in real-time using the Trimble VRS Now ${ }^{\circledR}$ service. The temporary bench mark and reference points were referenced to a horizontal datum of WGS 83 and vertical datum of NAVD 88. The Trimble ${ }^{\circledR} 5600$ DR 200+ Total Station was positioned at the established benchmark and the survey was corrected for position, rotation, and scale by shooting a prism at each reference point measuring its distance. With the Total Station survey setup complete, the direct reflex method was used to determine the positions of the water guns, hydrophones, and geophones that were recorded in the Trimble Survey Controller. Georeferencing targets located on the boom and a central point on the water gun platform were surveyed using direct reflex to determine the position of the hydrophone boom. At each water gun location, the water guns were secured at a fixed position and depth and fired at a constant pressure. When referencing equipment positions, the "center line" describes an imaginary line running between the water guns to the canal wall. Sensors were suspended in the water column at a fixed distance and depth and then moved sequentially in the water surrounding the water gun to record data. Five water gun shots were fired at each point location. For each shot, the maximum value was recorded (data are logged at 16,000 sps for $3 \mathrm{~s}$ following firing). The arithmetic mean of the five maximum values recorded at each hydrophone position and the processed location data were used to create the pressure map figures.

As with the Brandon Road study, seismic velocity data were collected using geophones and accelerometers. Water guns remained fixed for the second scenario, allowing for the geophones to be moved to various positions for more detailed coverage of the velocity response of the area behind the canal wall. Specific sensor positions are shown in the scenario descriptions (figs. 9 and 10). As many as six downhole 3C geophones and five R.T. Clark 3C surface geophones were used in the monitoring (figs. 9 and 10). The transverse component was oriented parallel with the canal (east-west) and the longitudinal component was oriented perpendicular (north-south) to the canal. The vertical component was perpendicular relative to ground surface.
Downhole geophones were placed inside one of three boreholes located on the site. These boreholes were drilled during the 2011 work (Morrow and others, 2015). Each borehole was a 3- or 4-in.-diameter hole drilled into the dolomite setblock used to build the canal walls. Each borehole was lined with steel casing until solid bedrock was reached, after which an open borehole continued until the end of the borehole. The boreholes initially were drilled to a depth of 30-40 ft bws, allowing placement of the downhole geophones at about the same elevation as mid-depth of the CSSC channel. The three boreholes were previously drilled 5, 35, and $100 \mathrm{ft}$ from the edge of the canal.

Accelerometers were placed on a mounting block and affixed to the vertical face of the right bank wall. They retained their alignment from the Brandon Road study with the vertical component unit mounted on top of the block and the longitudinal component unit mounted facing the canal.

All sensor positions were geolocated using a laser transit. Each configuration listed its distance from the edge of the wall, distance from the center line, and depth.

\section{Replicate Scenario}

Two 80 -in ${ }^{3}$ water guns were placed $90 \mathrm{ft}$ from the north wall of the CSSC (all geophones were placed generally north of this wall area within $100 \mathrm{ft}$ [fig. 9]). The two water gun platforms were fastened together and the water guns were suspended below them with a horizontal offset of about $6 \mathrm{ft}$ from one gun to another. The east gun was suspended from the upstream platform, and the west gun was suspended from the downstream platform (fig. 9). Both guns were suspended such that the guns were parallel with the flow of the CSSC and the gun ports were perpendicular to the walls of the CSSC. One gun port was at a depth of $4 \mathrm{ft}$ bws, and the other gun ports were at depths of $14 \mathrm{ft}$ bws. Beginning at $90 \mathrm{ft}$ from the north canal wall, with an operational pressure of $2,000 \mathrm{lb} / \mathrm{in}^{2}$ (the operational maximum), 15 shots were taken-firing first the 14-ft gun, then the 4-ft gun, and finally both guns together. Once the data were collected, the guns were moved closer to the north wall in 10-ft increments, and the cycle was repeated until a distance of $30 \mathrm{ft}$ from the wall was reached (Morrow and others, 2015).

Two downhole geophones were placed in each borehole- one geophone $5 \mathrm{ft}$ below ground surface (bgs) and one geophone 20-25 ft bgs (roughly to the same elevation as the 14-ft gun). A surface geophone was placed next to both the 5- and 35-ft boreholes (fig. 9). Each geophone was assigned an identifying color for reference.

The two hydrophone strings were placed along a line directly between the water guns and the north wall. The hydrophone strings were placed $5 \mathrm{ft}$ and $15 \mathrm{ft}$ from the wall, respectively (fig. 9), and remained fixed for the duration of the scenario. The 5 - $\mathrm{ft}$ buoy supported 12 hydrophones from 0 to $22 \mathrm{ft}$ bws at 2 -ft intervals. The 15-ft buoy supported 6 hydrophones from 12 to $22 \mathrm{ft}$ bws at 2 - $\mathrm{ft}$ intervals. 

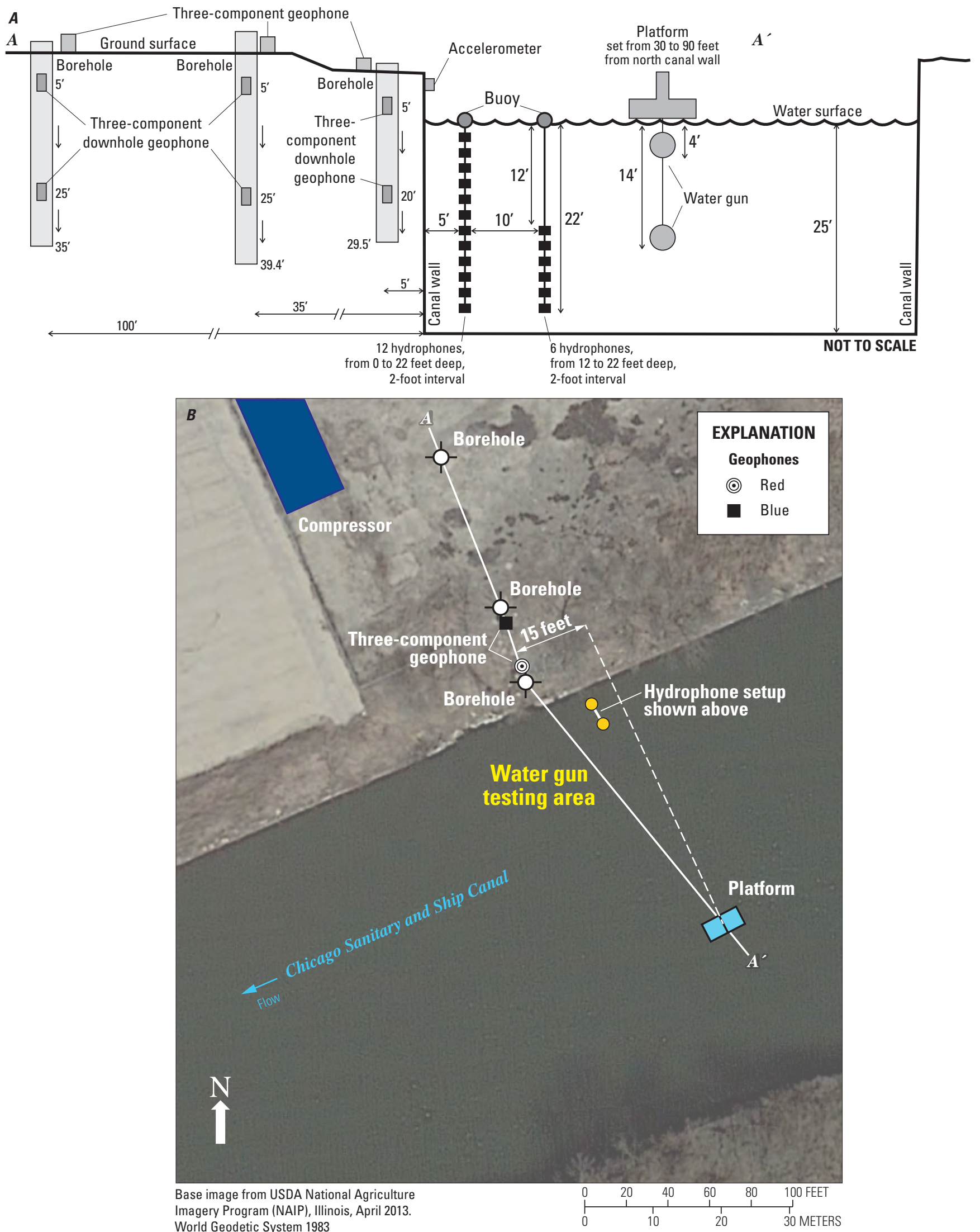

World Geodetic System 1983

Figure 9. Cross-sectional schematic diagram $(A)$ and plan view $(B)$ of 2011 replicate scenario, Chicago Sanitary Ship Channel, near Lemont, Illinois. 


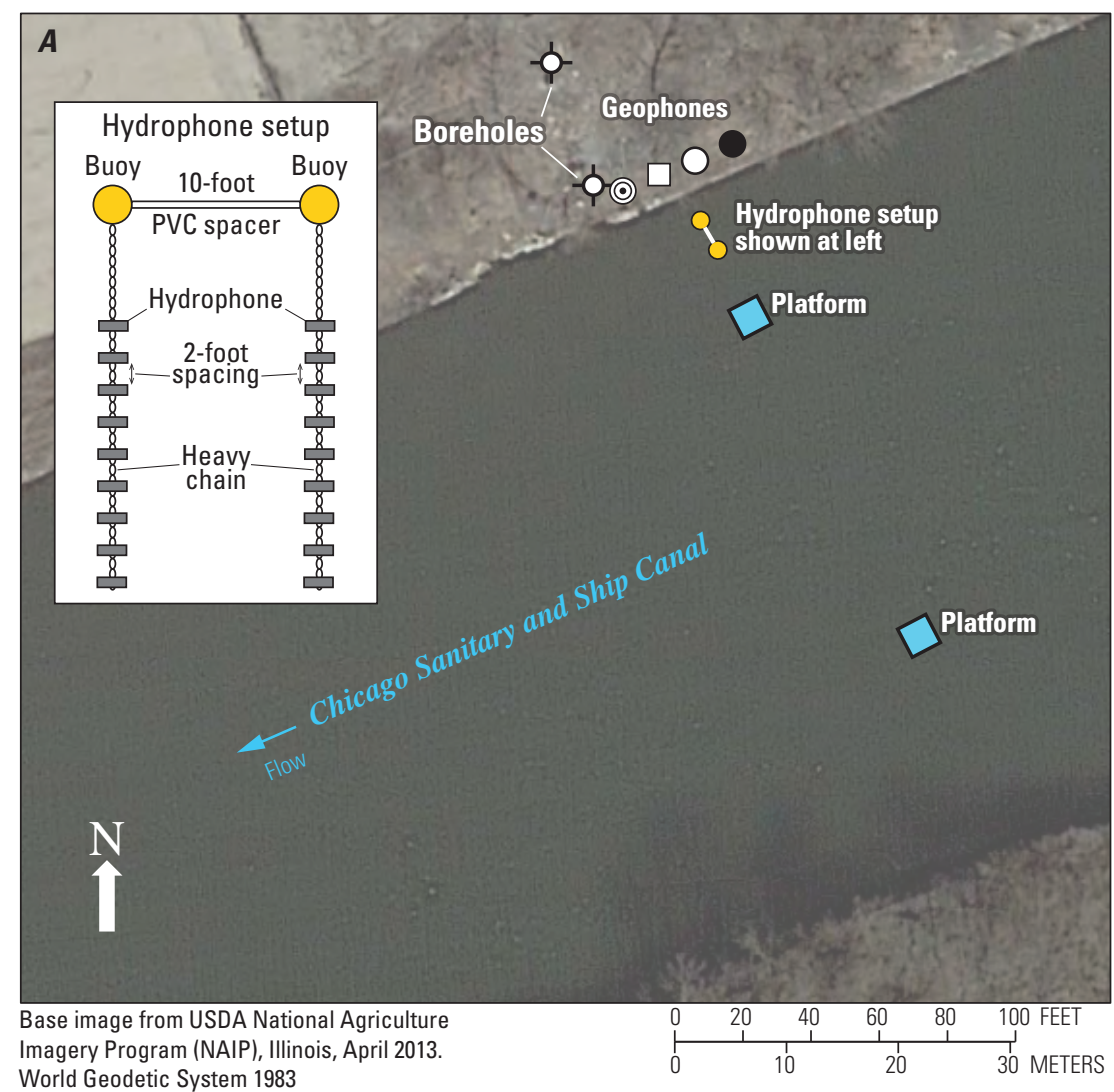

\section{EXPLANATION}

Geophones

White

$\square$ Green

- Pink

(a) Red

- Blue

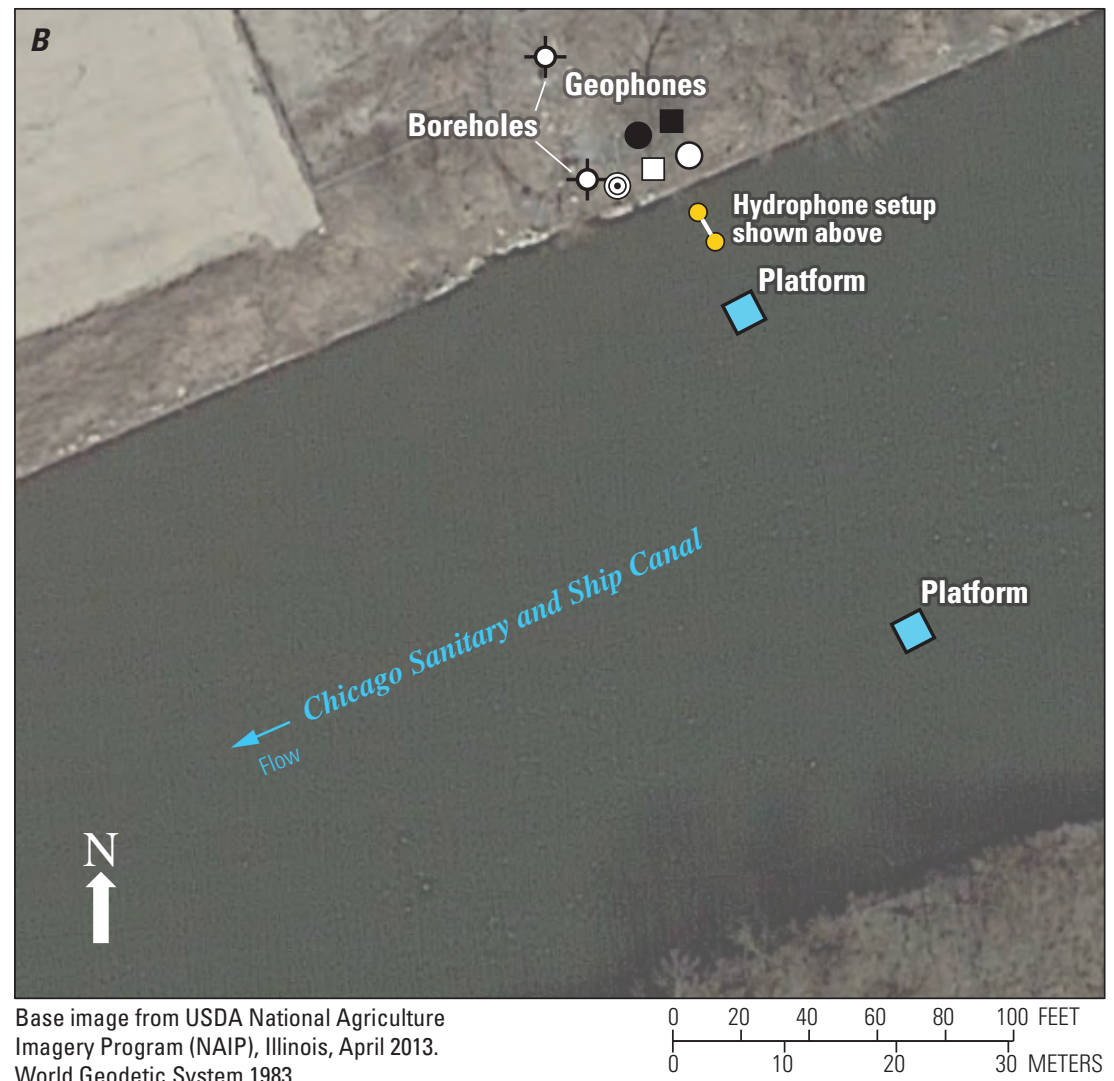
World Geodetic System 1983

Figure 10. Cross-sectional schematic diagram inset $(A)$, and plan views of double gun grid high pressure $(A)$ and low pressure $(B)$ scenarios, Chicago Sanitary Ship Channel, near Lemont, Illinois. 


\section{Double Gun Grid Scenario}

Two 80 -in ${ }^{3}$ water guns were placed along a line perpendicular to flow of the CSSC. Each water gun was placed $43 \mathrm{ft}$ from a canal wall, with a distance of $80 \mathrm{ft}$ between the two platforms. Water guns were suspended at a depth of $14 \mathrm{ft}$ bws with the gun ports aligned perpendicular to the walls. At each position, the water gun or guns were fired 10 times - 5 shots with only the northern gun (closer to the geophones) and 5 shots with both guns. This scenario was tested twice, once with a gun input pressure of $2,000 \mathrm{lb} / \mathrm{in}^{2}$ (fig. 10A) and, once with a gun input pressure of $1,000 \mathrm{lb} / \mathrm{in}^{2}$ (fig. 10B).

The surface and the 5-ft borehole geophones collected data during this scenario. Surface geophones were laid out with $10 \mathrm{ft}$ spacing between them. Geophones initially were arranged in a line, as in figure $10 \mathrm{~A}$, and then changed to a grid on the subsequent day (fig. 10B) to obtain better areal coverage.

The hydrophone strings were reconfigured to hold 9 hydrophones each at 2-ft increments from 6 to $22 \mathrm{ft}$ bws. The hydrophones were moved in 10-ft increments along three lines parallel (at distances of 20,30, and $40 \mathrm{ft}$ ) to the line created by the two water guns. Two to four additional data points were collected along the north wall as permitted by the pull of the water guns against the current and the suitability of anchor points on the north wall.

\section{Results for Water Pressure and Ground Vibrations}

\section{Brandon Road Water Pressure}

During the analysis of hydrophone data collected at Brandon Road, certain hydrophones were noted to have recorded pressure values an order of magnitude greater than the adjacent hydrophones on the same string. After analysis of the waveform data collected during each firing of the water gun (fig. 11), it was evident that the values were the result of an equipment malfunction and were excluded from all analyses and pressure maps.

\section{Varying Gun Distance Scenario}

This scenario was run as a series of increasing pressure tests at decreasing wall distances to determine the operational limits of the water guns within the confined space of the channel as defined by the USACE.

The variations in pressure, as monitored by the hydrophone at $8 \mathrm{ft}$ bws in a group of hydrophones placed $1 \mathrm{ft}$ from the testing wall, are shown in figure 12. Of the 6 hydrophones in this group, mounted at depths of $0,2,4$,
6, 8, and $9 \mathrm{ft}$ bws, respectively, hydrophones at 6, 8 and $9 \mathrm{ft}$ bws had some pressures greater than $5 \mathrm{lb} / \mathrm{in}^{2}$, but only the 8 -ft bws hydrophone consistently recorded pressures greater than $5 \mathrm{lb} / \mathrm{in}^{2}$.

To keep pressures near the wall lower than the 5 -lb/in ${ }^{2}$ threshold, gun input pressures should be no greater than $700 \mathrm{lb} / \mathrm{in}^{2}$ when the gun is positioned at distances of 55 and $50 \mathrm{ft}$ from the testing wall and no greater than $500 \mathrm{lb} / \mathrm{in}^{2}$ when the gun is at distances of $45 \mathrm{ft}$ from the testing wall. With $500 \mathrm{lb} / \mathrm{in}^{2}$ as the minimum input pressure for the 80 -in ${ }^{3}$ water gun, testing was concluded with the water gun $45 \mathrm{ft}$ from the testing wall.

\section{Single Gun Radial Scenario}

The single gun radial scenario was run to understand the extent and azimuthal variability of the pressure field. Contoured pressure results at different depths with a gun input pressure of $700 \mathrm{lb} / \mathrm{in}^{2}$ and gun ports at a depth of $6 \mathrm{ft}$ bws are shown in figures 13-18.

Data showed generally symmetrical pressures that gradually increased or decreased over depth with no large variations (figs. 13-18). The radial extent of the pressure data was maximized at the 6-ft depth of the water gun (fig. 16), with the $5-\mathrm{lb} / \mathrm{in}^{2}$ threshold pressure reached across a radius of about $20 \mathrm{ft}$. This radius decreased above and below the water gun depth of $6 \mathrm{ft}$. The extent of the decrease is much greater above the gun, with the map at the surface showing no areas of threshold pressure (data points were removed from the surface map because of an equipment malfunction, as described in the "Brandon Road Water Pressure" section). If considered vertically, the shape of the $5-\mathrm{lb} / \mathrm{in}^{2}$ pressure field contour generally is that of a slightly eccentric circle resulting in a somewhat cylindrical pressure field extending from the bottom of the canal (fig. 18) to the 2-ft map (fig. 14) before sharply diminishing as it approaches the surface (fig. 13). Pressure is not measured from 0 to $15 \mathrm{ft}$ from the water gun (the exclusion zone boundary) because of the risk of damaging the hydrophones.

\section{Static Boom High Pressure Scenario}

One water gun was placed $55 \mathrm{ft}$ from the wall, and suspended at $6 \mathrm{ft}$ bws, and a second gun was added later at a depth of $8 \mathrm{ft}$ bws. The hydrophone boom was placed in line with the gun, pointing perpendicular to the testing wall. Data collection focused on when water guns were fired at input pressures of 1,000-2,000 lb/in ${ }^{2}$ to understand the response of the structure to higher-amplitude pressure waves, compared to the previous scenarios. The results of the static boom high pressure scenario designed to test limited exposure to high pressures and represent a smaller number of shots (2-4) at pressures beginning at 1,000 lb/in ${ }^{2}$ are shown in figures 19-21. 


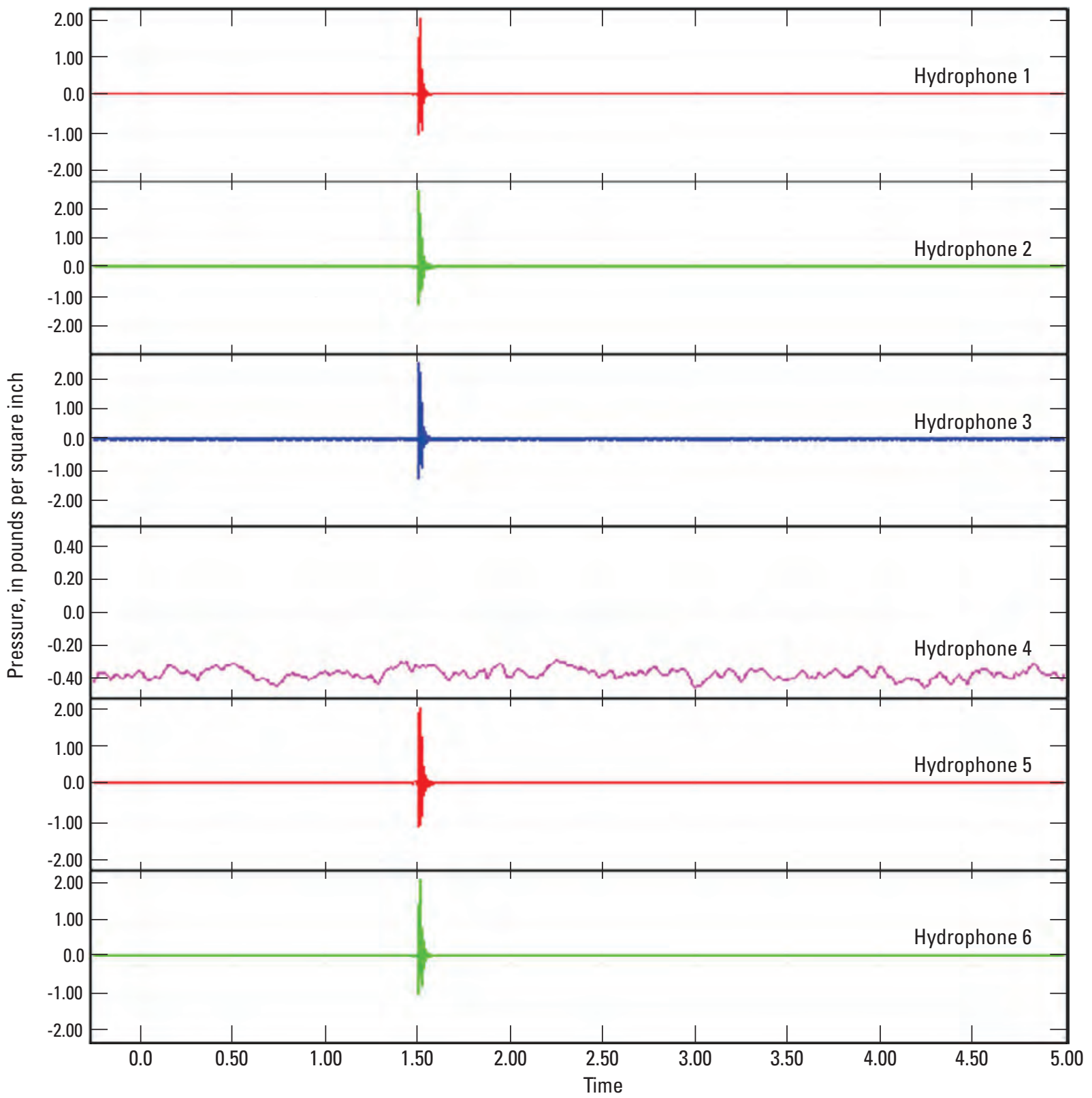

Figure 11. Effects of equipment malfunction on waveform data from a single hydrophone (pink line, Hydrophone 4), Brandon Road study, Des Plaines River, near Joliet, Illinois. 


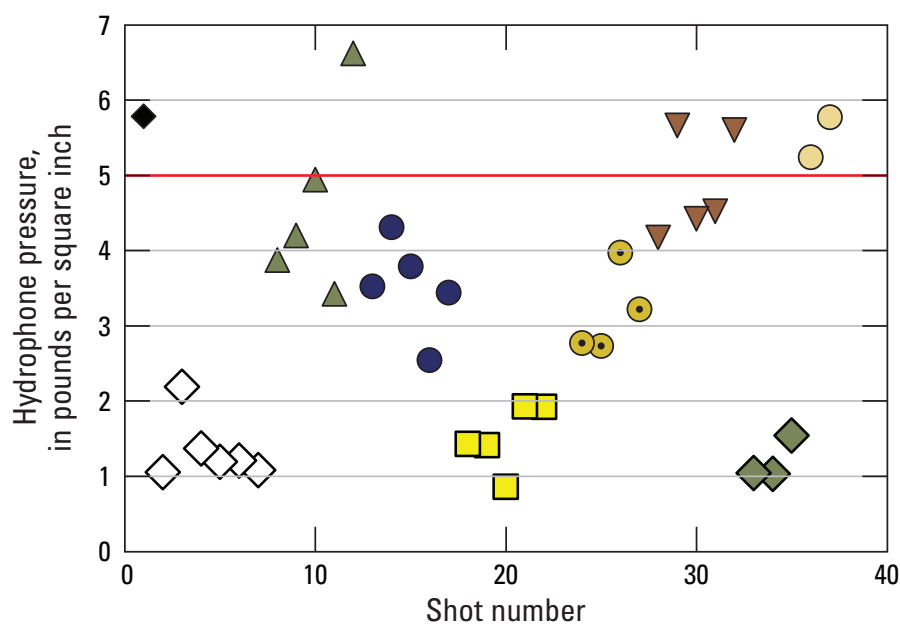

\section{EXPLANATION}

Water gun distance from wall and firing pressure

- 55 feet $1,000 \mathrm{lb} / \mathrm{in}^{2}$

$\diamond \quad 55$ feet $500 \mathrm{lb} / \mathrm{in}^{2}$

$\triangle 55$ feet $750 \mathrm{lb} / \mathrm{in}^{2}$

- $\quad 55$ feet $700 \mathrm{lb} / \mathrm{in}^{2}$

$\square \quad 50$ feet $500 \mathrm{lb} / \mathrm{in}^{2}$

॰ 50 feet $700 \mathrm{lb} / \mathrm{in}^{2}$

$\nabla \quad 50$ feet $750 \mathrm{lb} / \mathrm{in}^{2}$

$\diamond \quad 45$ feet $500 \mathrm{lb} / \mathrm{in}^{2}$

O 45 feet $700 \mathrm{lb} / \mathrm{in}^{2}$

Figure 12. Pressure data from a hydrophone placed 1 foot from testing wall at depth of 8 feet below water surface, Brandon Road study, Des Plaines River, near Joliet, Illinois. Graph indicates progression of pressure changes as water gun distance and input pressure were modified.

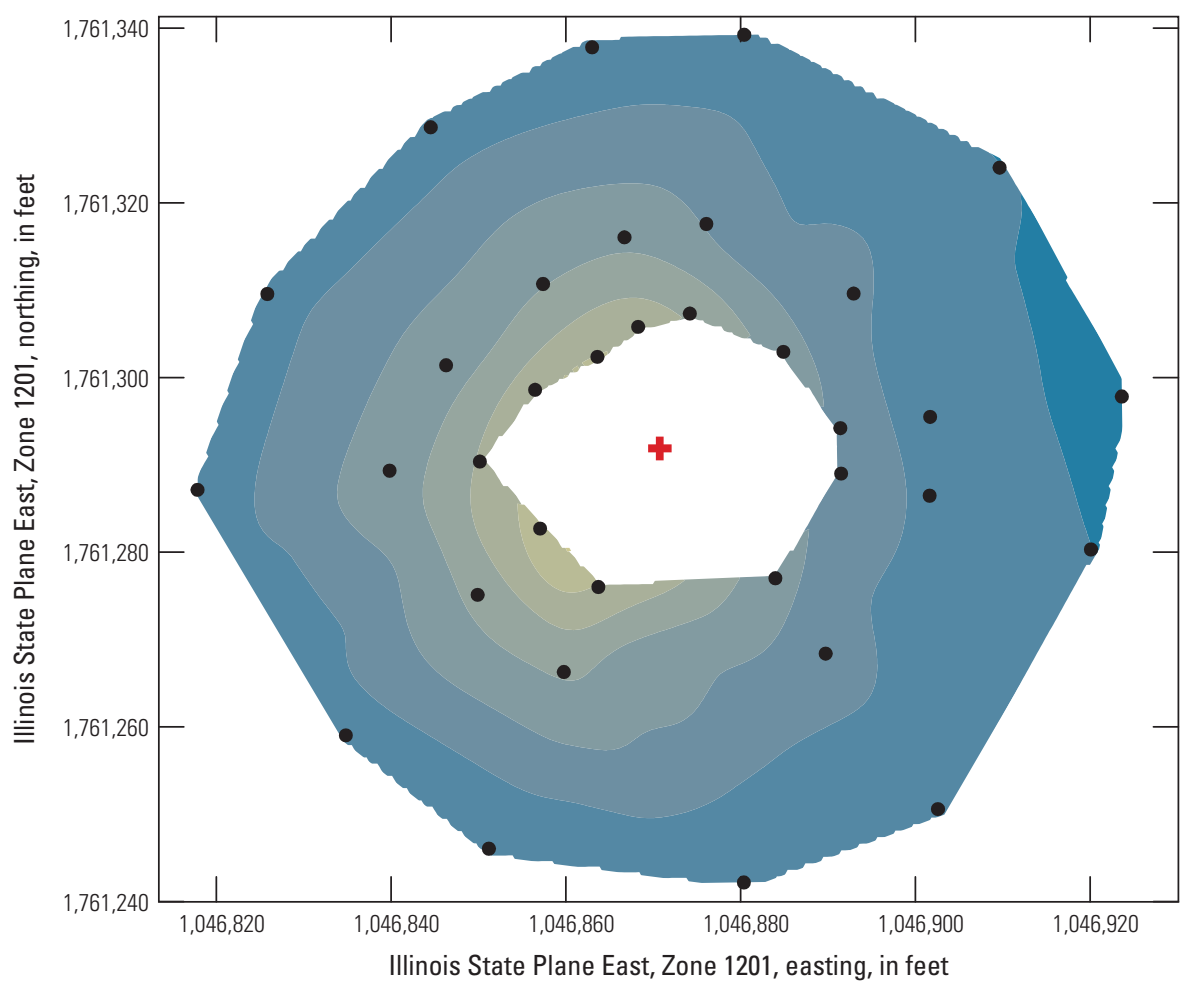

\section{EXPLANATION}

Pressure, in pounds per square inch

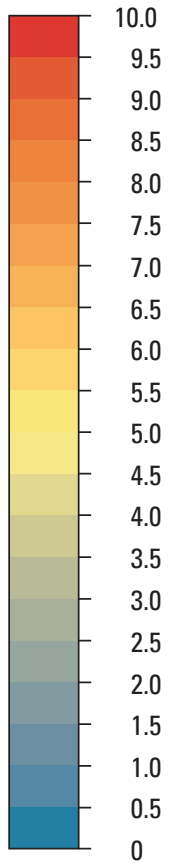

$+\quad$ Water gun

- Hydrophone group position

Figure 13. Pressure measurements at water surface from a single 80 -cubic-inch water gun fired at 700 pounds per square inch, Brandon Road study, Des Plaines River, near Joliet, Illinois. 

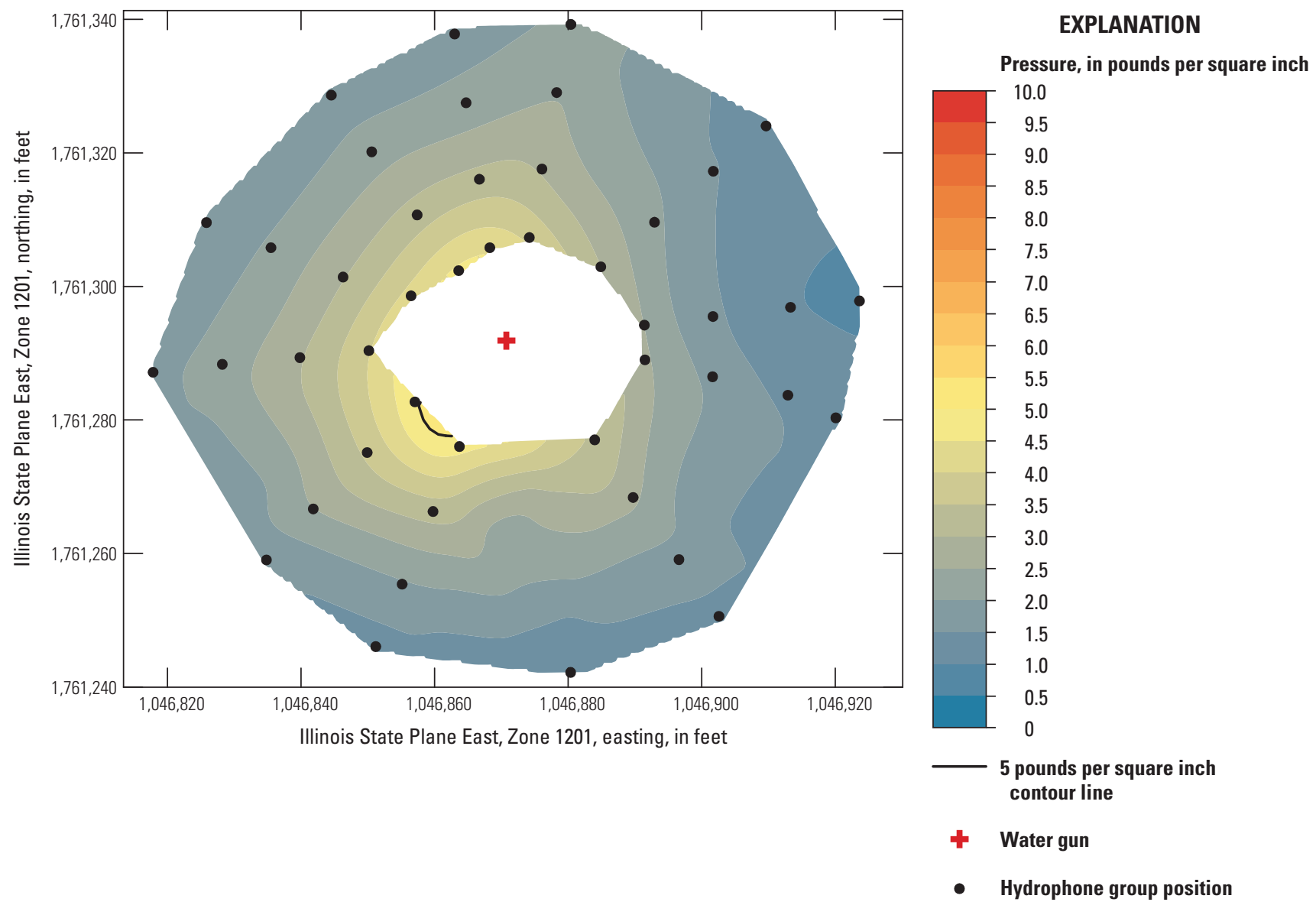

Figure 14. Pressure measurements at a depth of 2 feet below water surface from a single 80-cubic-inch water gun fired at 700 pounds per square inch, Brandon Road study, Des Plaines River, near Joliet, Illinois. 

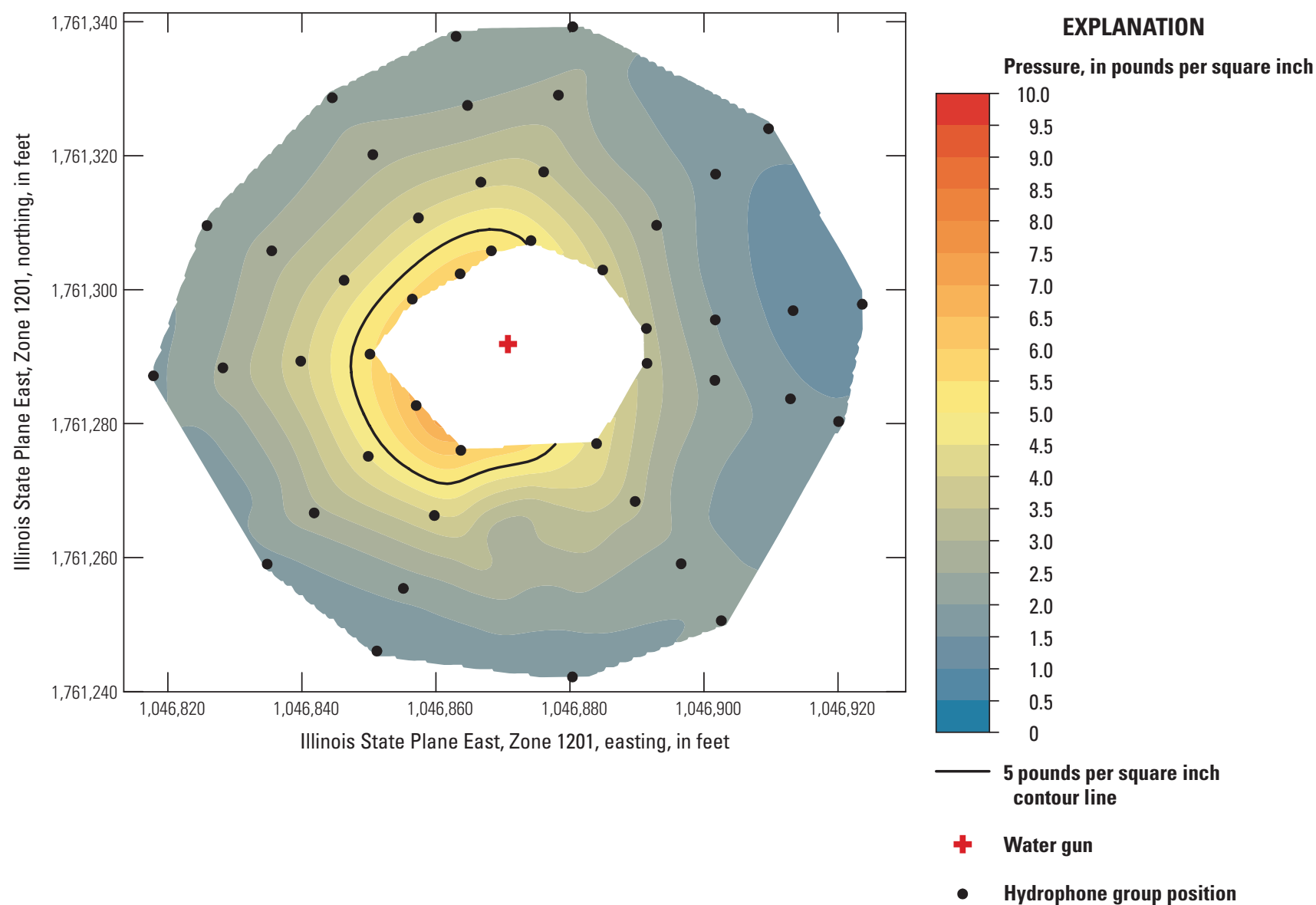

Figure 15. Pressure measurements at a depth of 4 feet below water surface from a single 80-cubic-inch water gun fired at 700 pounds per square inch, Brandon Road study, Des Plaines River, near Joliet, Illinois. 

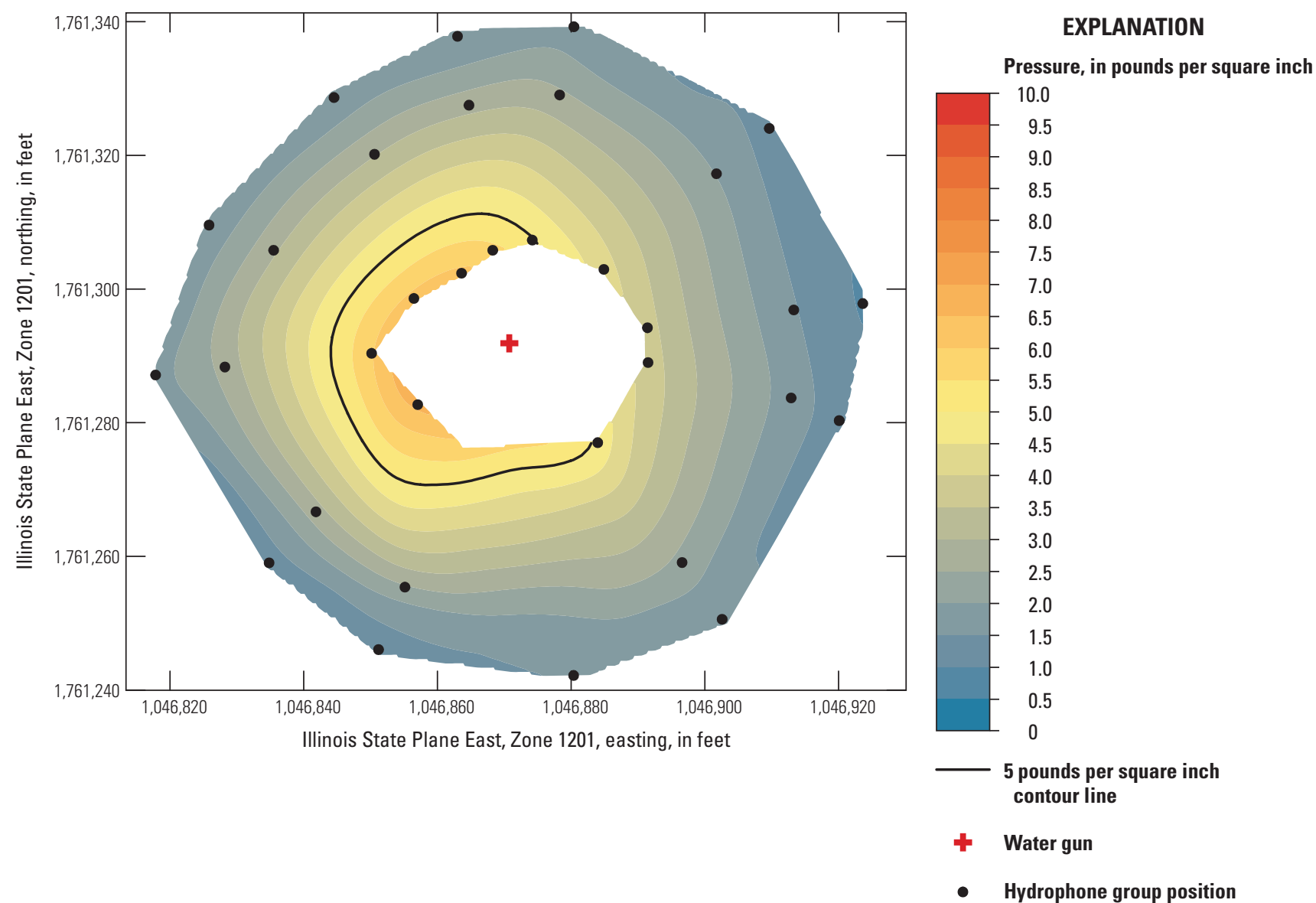

Figure 16. Pressure measurements at a depth of 6 feet below water surface from a single 80-cubic-inch water gun fired at 700 pounds per square inch, Brandon Road study, Des Plaines River, near Joliet, Illinois. 

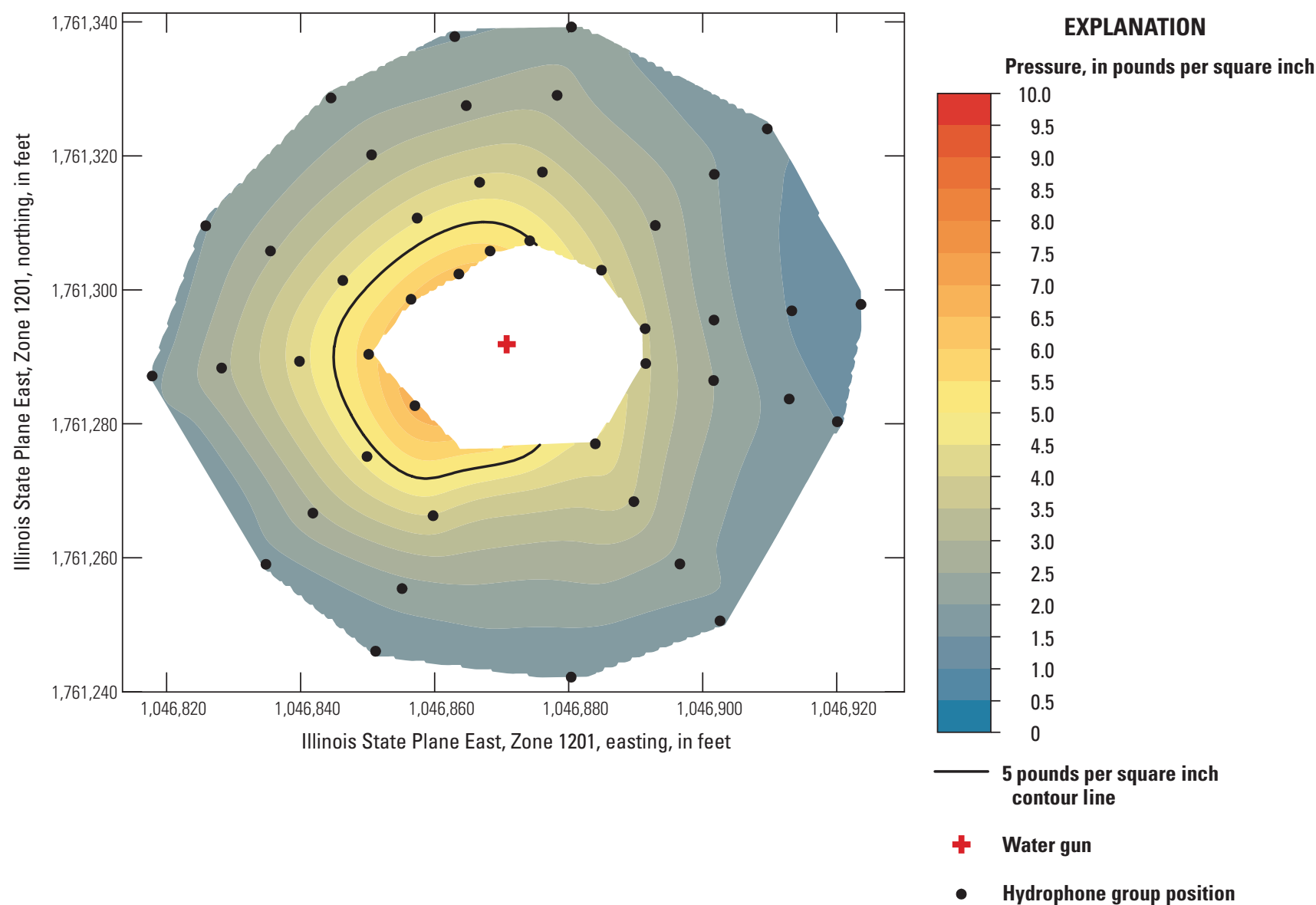

Figure 17. Pressure measurements at a depth of 8 feet below water surface from a single 80 -cubic-inch water gun fired at 700 pounds per square inch, Brandon Road study, Des Plaines River, near Joliet, Illinois. 

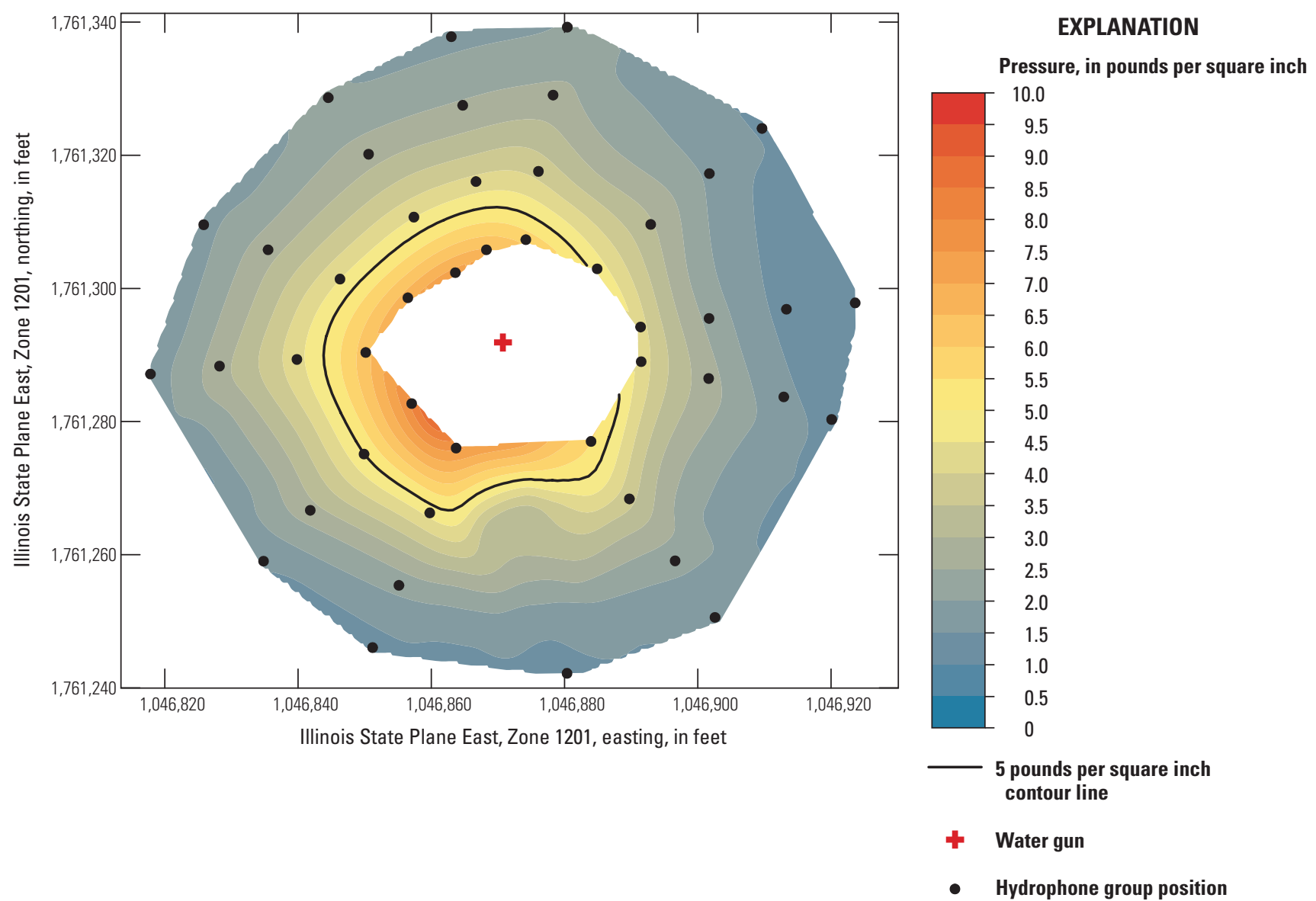

Figure 18. Pressure measurements at a depth of 9 feet below water surface from a single 80-cubic-inch water gun fired at 700 pounds per square inch, Brandon Road study, Des Plaines River, near Joliet, Illinois.

During some of the trials (figs. 20 and 21), data from the fourth string of hydrophones (located closest to the water gun) were not collected so that the seismograph normally used to collect that data could be used to collect additional geophone data. Specific details of the setup are noted in the figure captions.

In the first part of this scenario, a single 80 -in ${ }^{3}$ water gun at a depth of $6 \mathrm{ft}$ bws was fired at 1,000, 1,500, and $2,000 \mathrm{lb} / \mathrm{in}^{2}$. The images shown in figure 19 represent a vertical profile through the canal situated along the center line of the setup directly between the water gun and the wall. The three profiles showed pressure generally decreasing both vertically and horizontally as the horizontal distance from the water gun increases. The pressure field distribution shows an approximately radial expansion from the point of origin.

The extent of the $5-\mathrm{lb} / \mathrm{in}^{2}$ threshold pressure varies based on the water gun input pressure. The extent of the 5 -lb/in ${ }^{2}$ threshold pressure difference between 1,000 (fig. 19A) and 1,500 lb/in² (fig. 19B) is substantial, with nearly 10 additional $\mathrm{ft}$ contained with the threshold. Similar trends in the pressure data from the varying gun distance scenario confirm that changing the gun input pressure from 1,000 to $1,500 \mathrm{lb} / \mathrm{in}^{2}$ can result in large changes in extent of the pressure field. However, differences between 1,500 (fig. 19B) and 2,000 lb/in (fig. 19C) are much smaller, and primarily are variations in intensity rather than extent of the pressure field. This result could indicate that each environment has a certain tolerance for pressure and that once the optimal gun input pressure is exceeded, further increases in the extent of the pressure field would be limited. Pressures at the water surface are much lower than pressures at depth, even in close proximity to the water gun (fig. 19).

The second part of this scenario involved the addition of a second $80-\mathrm{in}^{3}$ water gun at a depth of $8 \mathrm{ft}$ bws and oriented perpendicular to the water gun at $6 \mathrm{ft}$ bws. The 8 - $\mathrm{ft}$ gun and then both guns were fired in a 10 -shot sequence. The first five firings were with the 8 - $\mathrm{ft}$ gun, and the last five firings with both guns. This sequence was repeated as pressure increased from 500 to $1,000 \mathrm{lb} / \mathrm{in}^{2}$ at an interval of $100 \mathrm{lb} / \mathrm{in}^{2}$. A series of profiles from each of the water gun configurations is shown in figure 20.

The effect of rotating the water gun can be seen in the extent of the pressure field. The $5-1 \mathrm{~b} / \mathrm{in}^{2}$ contour line moves $10 \mathrm{ft}$ closer to the water gun in the 8-ft image (fig. 20B) relative to the 6-ft image (fig. 20A). The 6-ft profile (fig. 20A) projects the target pressure out to a similar distance from the wall compared to the two gun profile (fig. 20C). 


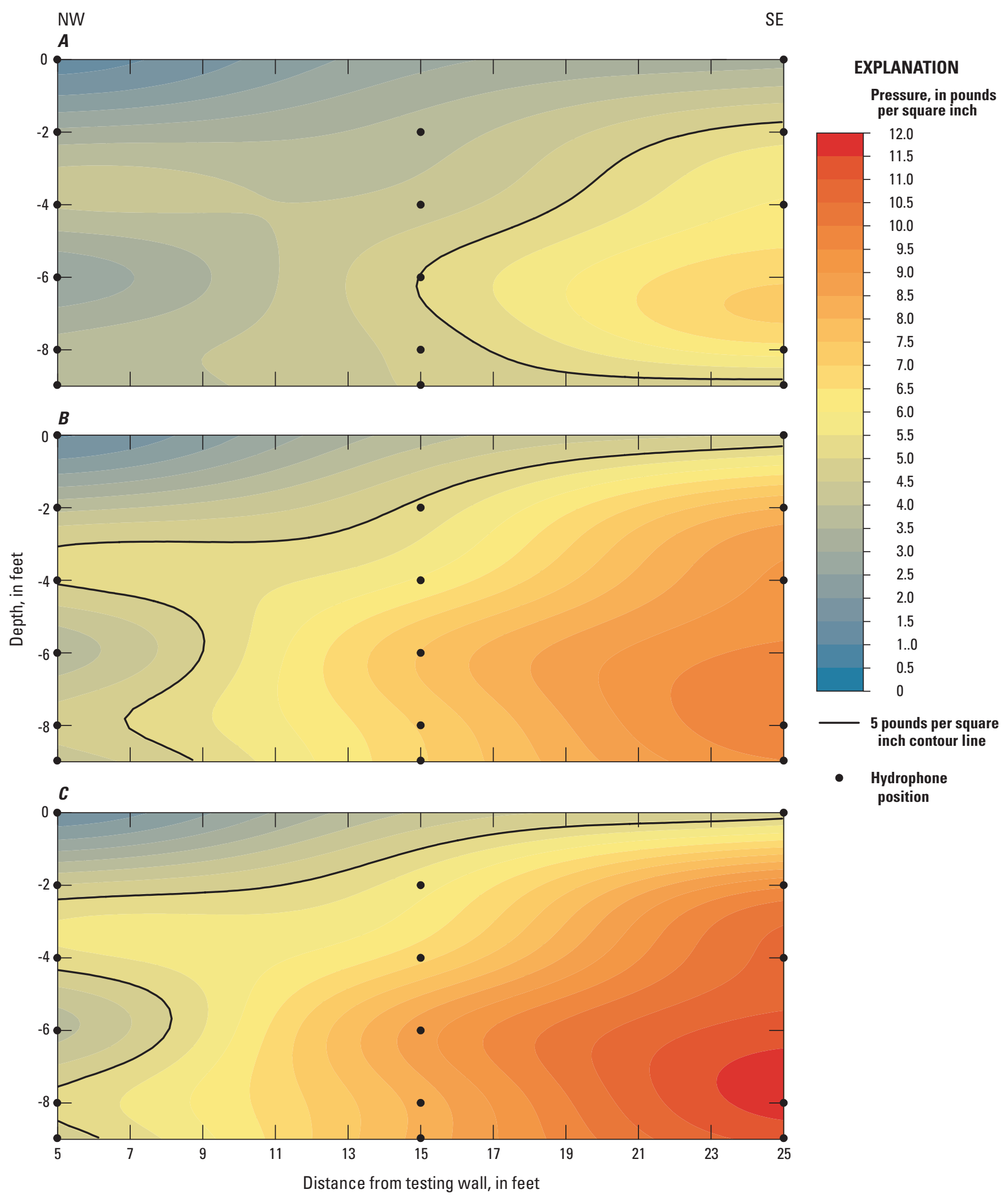

Figure 19. Spatial distribution of pressure for a single 80-cubic-inch water gun placed 55 feet from the testing wall, 6 feet below the water surface, and fired at $(A)$ 1,000, $(B)$ 1,500, and $(C)$ 2,000 pounds per square inch, Brandon Road study, Des Plaines River, near Joliet, Illinois. 


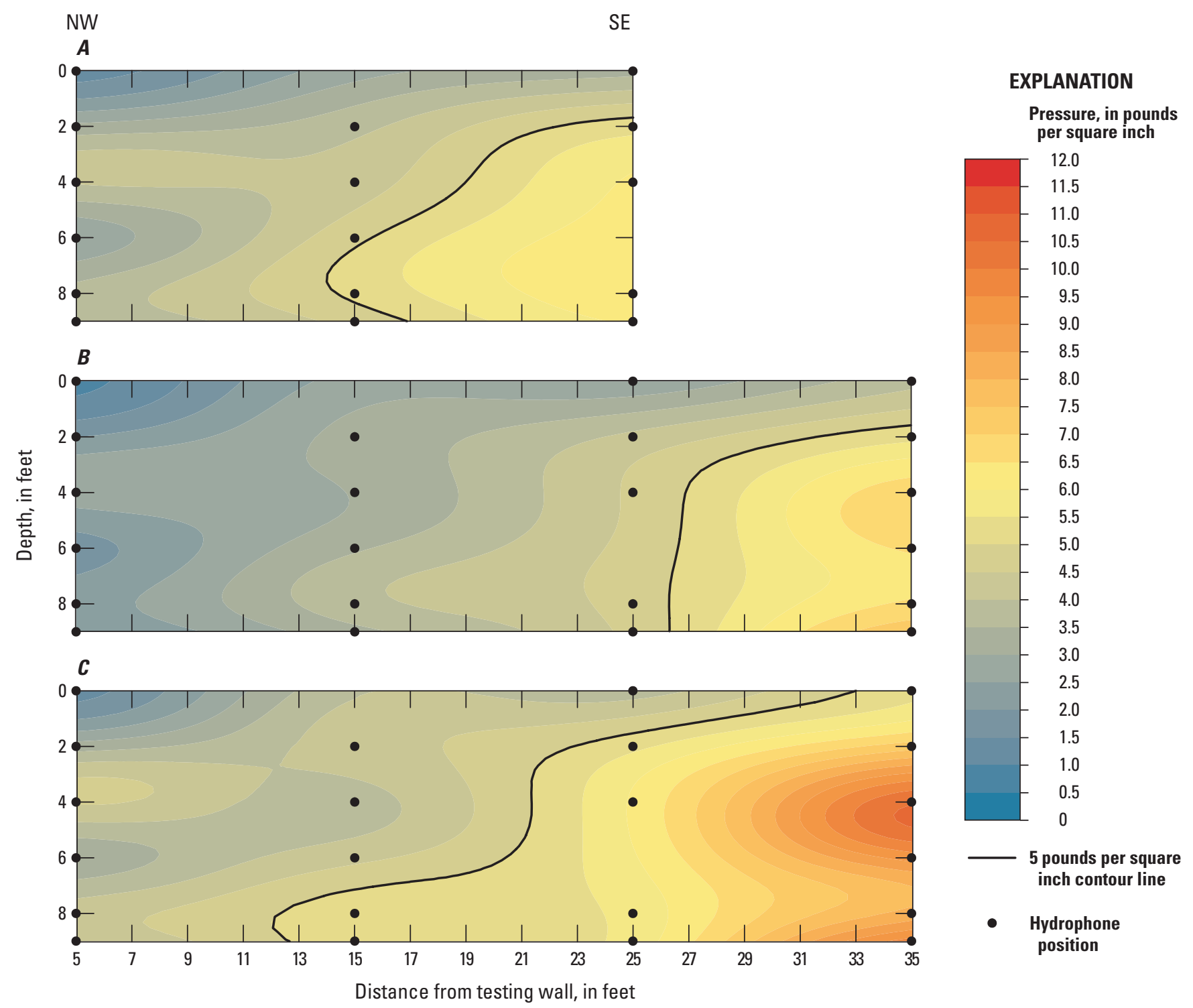

Figure 20. Spatial distribution of pressure for single 80-cubic-inch water guns placed 6 feet below water surface $(A)$ and 8 feet below water surface oriented orthogonally to the first water gun $(B)$, and for two 80-cubic-inch water guns placed 6 and 8 feet below water surface, respectively $(C)$, all 55 feet from the testing wall and fired at 1,000 pounds per square inch, Brandon Road study, Des Plaines River, near Joliet, Illinois.

In the third part of this scenario, gun positions were kept the same and gun input pressure was changed. Two water guns were both fired at pressures of $1,300 \mathrm{lb} / \mathrm{in}^{2}$, $1,500 \mathrm{lb} / \mathrm{in}^{2}$ and 2,000 lb/in' ${ }^{2}$. The differences between firing a single water gun at $6 \mathrm{ft}$ and firing both water guns at $6 \mathrm{ft}$ and $8 \mathrm{ft}$ are shown in figure $21 \mathrm{for}$ a pressure of $2,000 \mathrm{lb} / \mathrm{in}^{2}$. The two gun profile (fig. $21 B$ ) is constructed from a simultaneous firing of both water guns. The radial extent of the target pressure is similar between the two profiles. Both profiles show a nearly total threshold pressure coverage of the channel, with only small areas along the wall remaining at less than the $5 \mathrm{lb} / \mathrm{in}^{2}$ threshold pressure. 


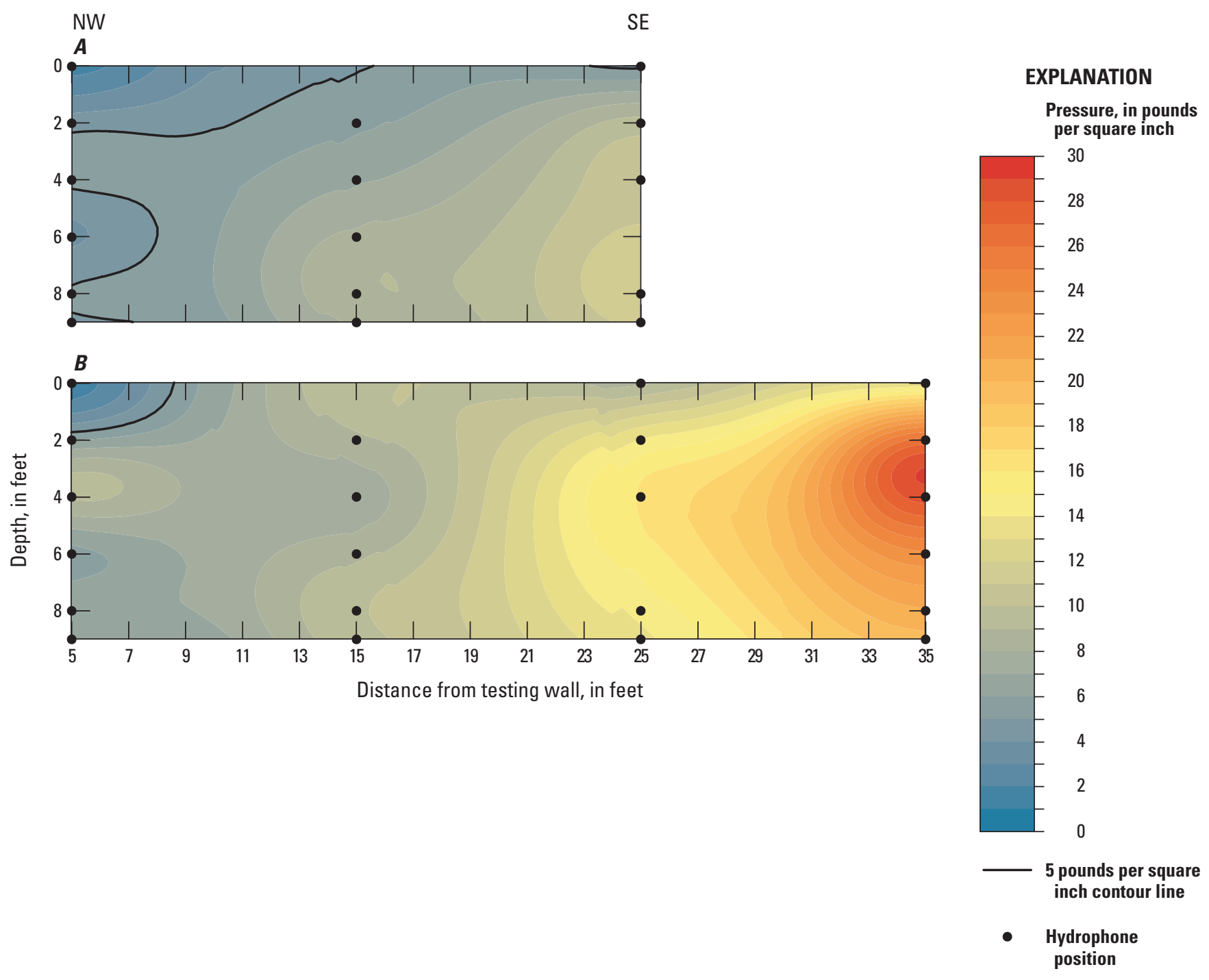

Figure 21. Spatial distribution of pressure for a single 80-cubic-inch water gun 6 feet below water surface $(A)$, and for two 80 -cubic-inch water guns 6 and 8 feet below water surface $(B)$, all 55 feet from the testing wall and fired at a pressure of 2,000 pounds per square inch, Brandon Road study, Des Plaines River, near Joliet, Illinois.

\section{Double Gun Radial Scenario}

The double gun radial scenario was designed to understand the pressure field surrounding two water guns (figs. 22-27) and compare those results to the single gun radial scenario.

The addition of a second water gun and an increase in input gun pressure from $700 \mathrm{lb} / \mathrm{in}^{2}$ to $1,000 \mathrm{lb} / \mathrm{in}^{2}$ resulted in an increase in the radial extent of the $5-1 \mathrm{~b} / \mathrm{in}^{2}$ pressure field. The radius of the threshold pressure increased by a distance of greater than $15 \mathrm{ft}$ compared to the single gun radial setup (fig. 28), but decreased from the bottom depth of $9 \mathrm{ft}$ (fig. 27) up to the 2-ft depth (fig. 23) and then diminished substantially at the surface (fig. 22) in a similar manner to the single gun maps.

The orthogonally placed gun ports on the deeper 8-ft water gun (relative to the $6-\mathrm{ft}$ water gun) seem to reduce the horizontal eccentricity of the pressure field (figs. 22-27). Although the change in shape was expected, some of the eccentricity may be due to a decrease in sampling density. 


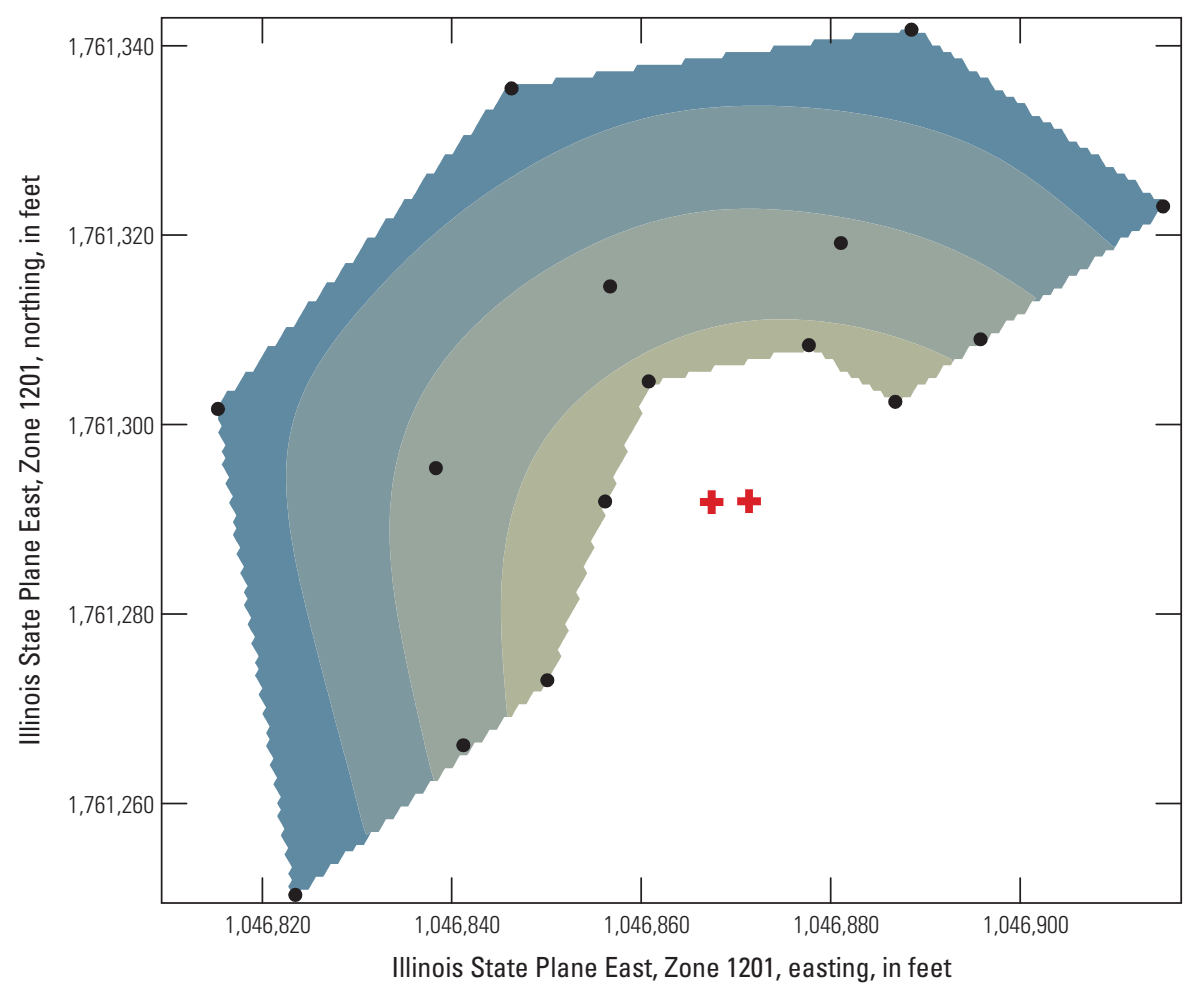

\section{EXPLANATION}

Pressure, in pounds per square inch

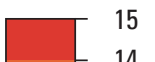

15
$-\quad 14$

$-13$

$-12$

$-11$

$-10$

$-9$

$-\quad 8$
-7

7
$-\quad 6$

$-5$

$-4$

3
$-\quad 2$

2
$-\quad 1$
0

$+\quad$ Water gun

- Hydrophone group position

Figure 22. Pressure measurements at water surface from two 80-cubic-inch water guns fired at 1,000 pounds per square inch, Brandon Road study, Des Plaines River, near Joliet, Illinois.

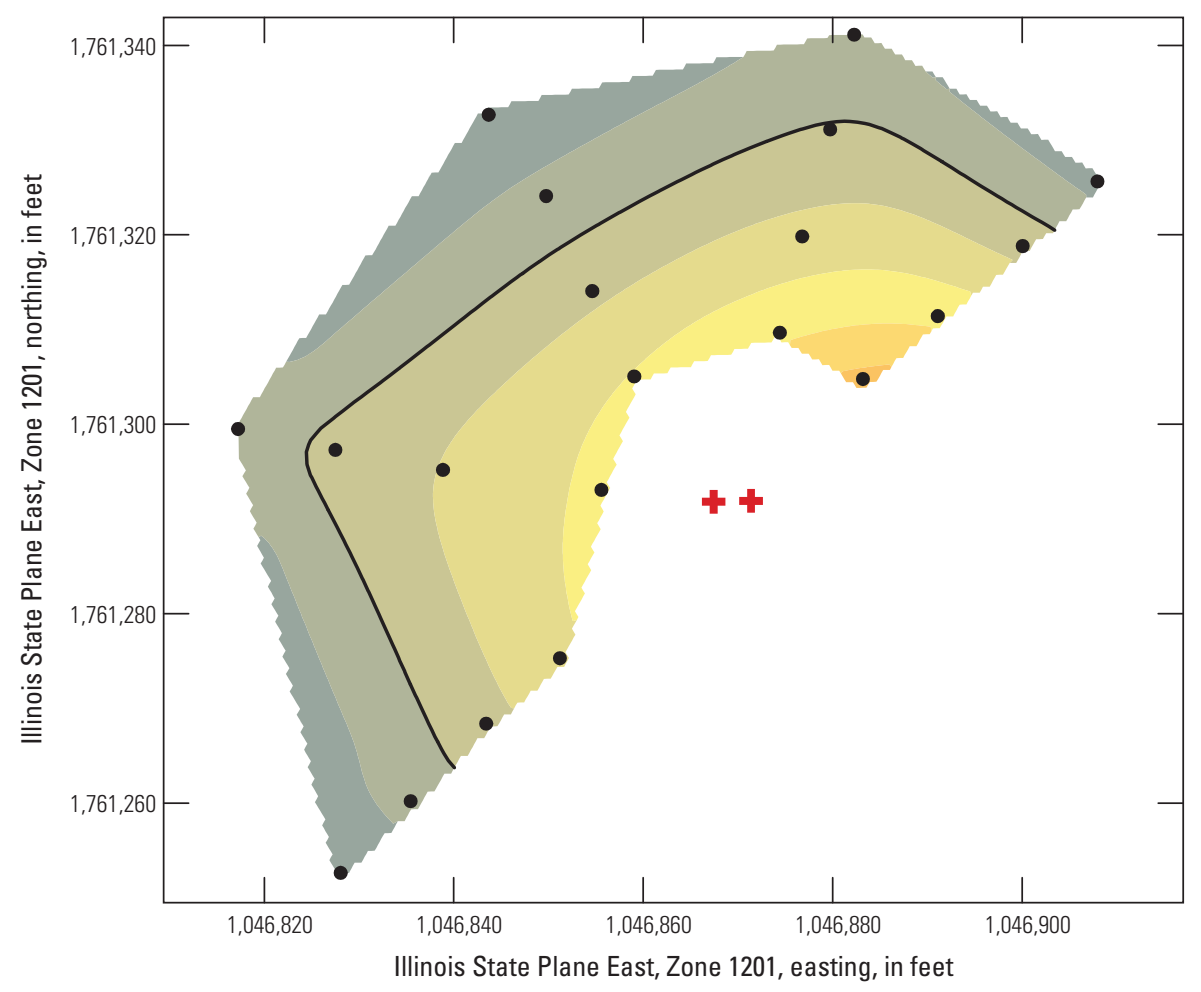

\section{EXPLANATION}

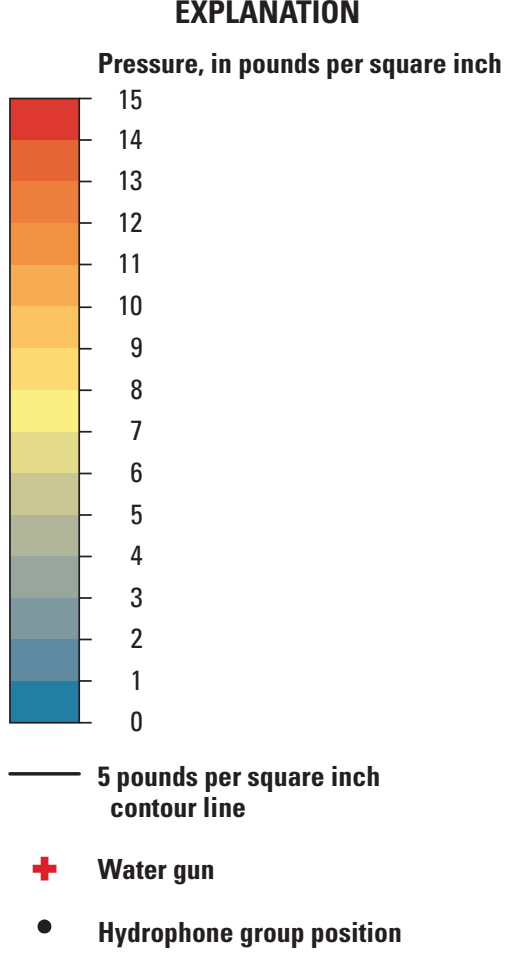

Figure 23. Pressure measurements at a depth of 2 feet below water surface from two 80 -cubic-inch water guns fired at 1,000 pounds per square inch, Brandon Road study, Des Plaines River, near Joliet, Illinois. 

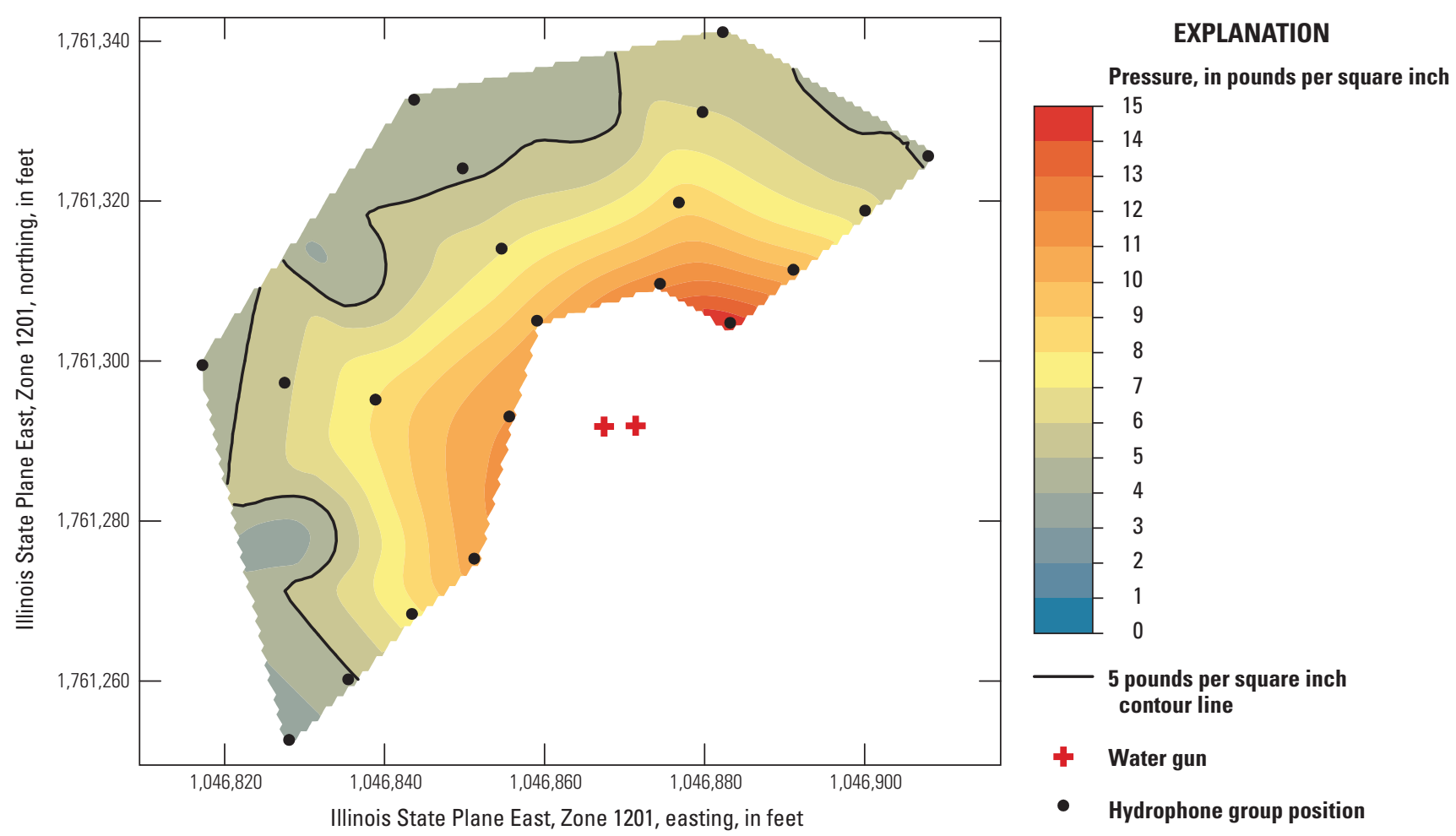

Figure 24. Pressure measurements at a depth of 4 feet below water surface from two 80-cubic-inch water guns fired at 1,000 pounds per square inch, Brandon Road study, Des Plaines River, near Joliet, Illinois.

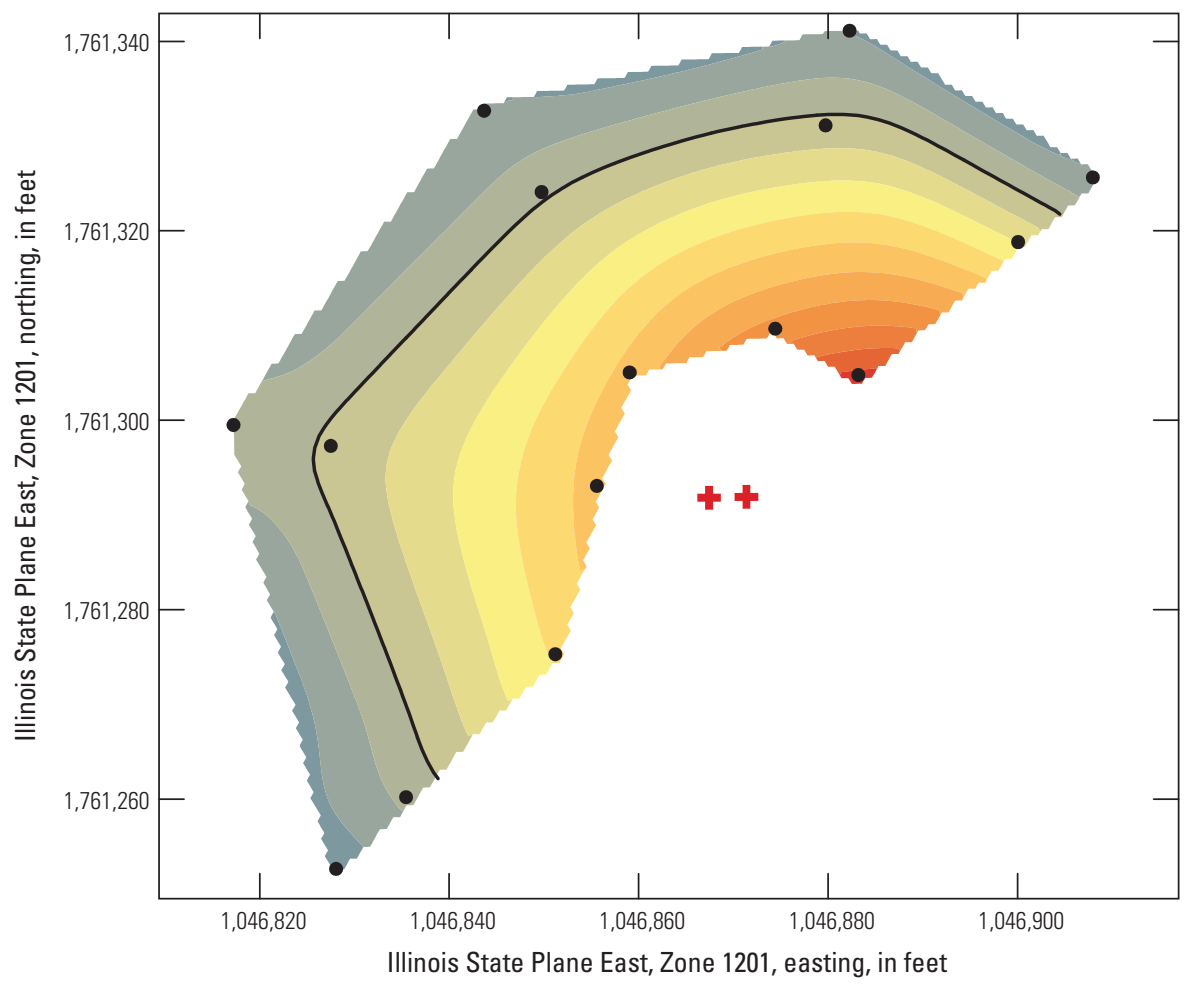

\section{EXPLANATION}

Pressure, in pounds per square inch

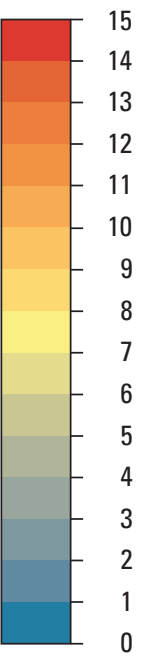

5 pounds per square inch contour line

+ Water gun

- Hydrophone group position

Figure 25. Pressure measurements at a depth of 6 feet below water surface from two 80-cubic-inch water guns fired at 1,000 pounds per square inch, Brandon Road study, Des Plaines River, near Joliet, Illinois. 

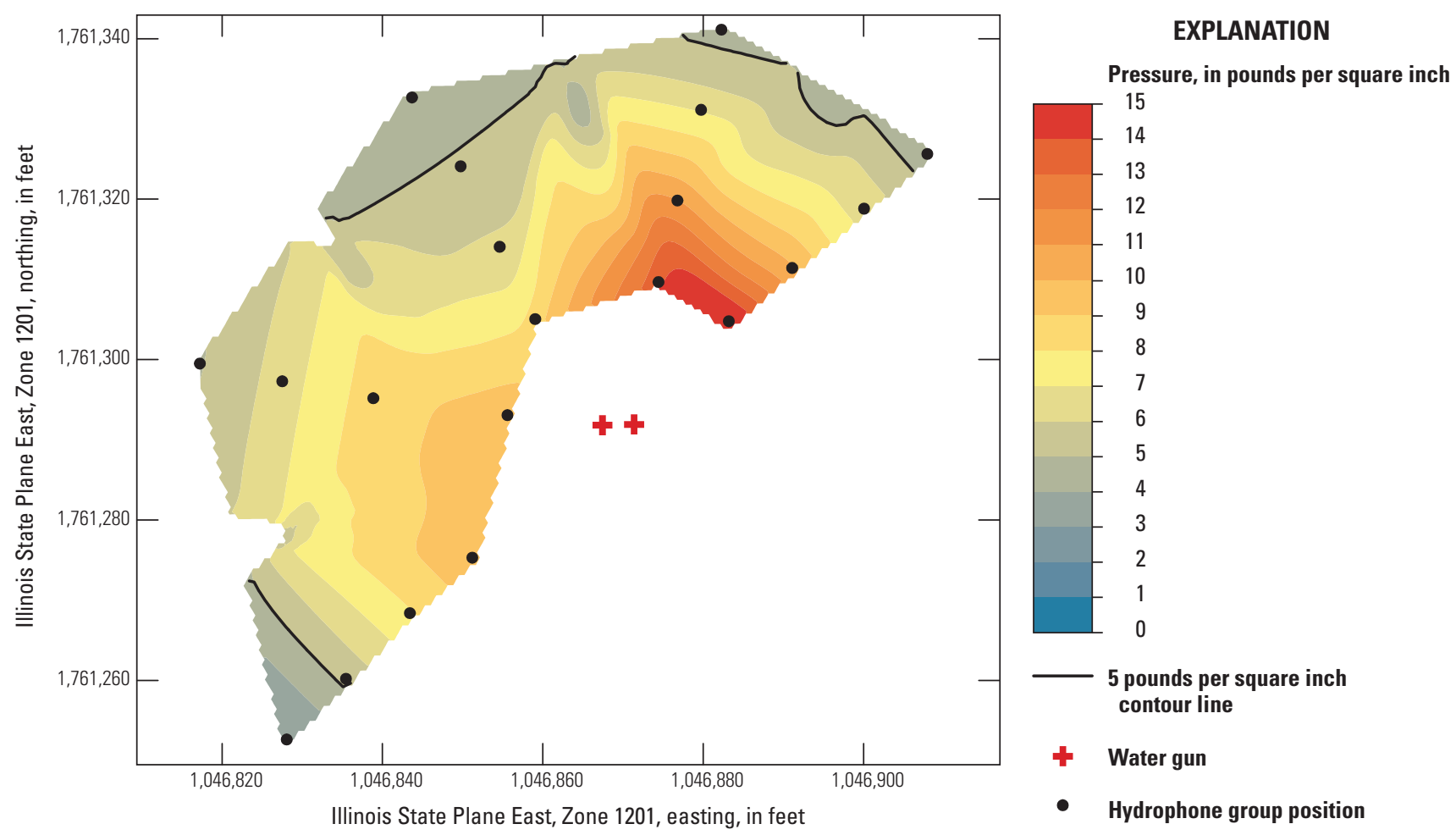

Figure 26. Pressure measurements at a depth of 8 feet below water surface from two 80-cubic-inch water guns fired at 1,000 pounds per square inch, Brandon Road study, Des Plaines River, near Joliet, Illinois.
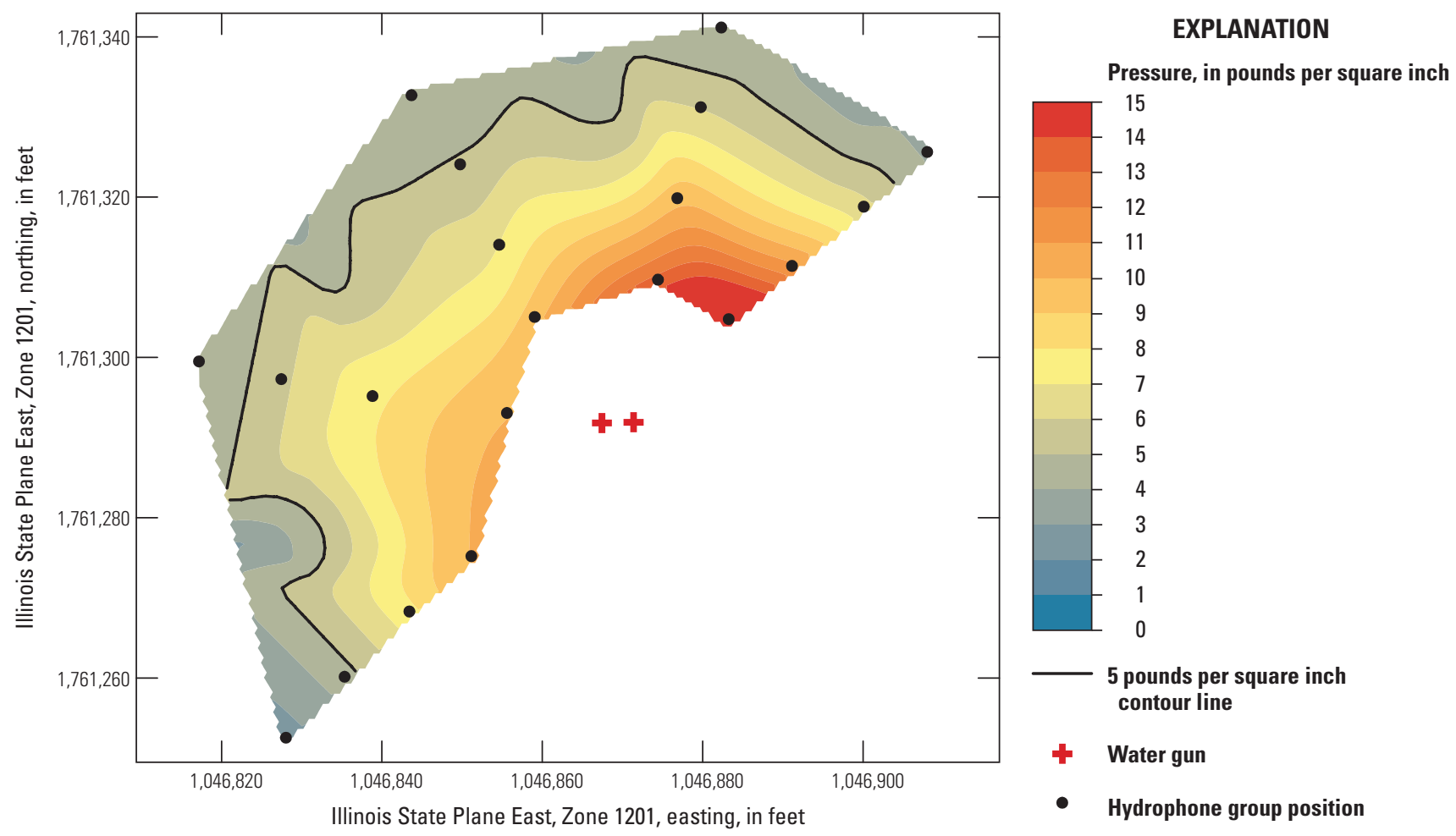

Figure 27. Pressure measurements at a depth of 9 feet below water surface from two 80-cubic-inch water guns fired at 1,000 pounds per square inch, Brandon Road study, Des Plaines River, near Joliet, Illinois. 


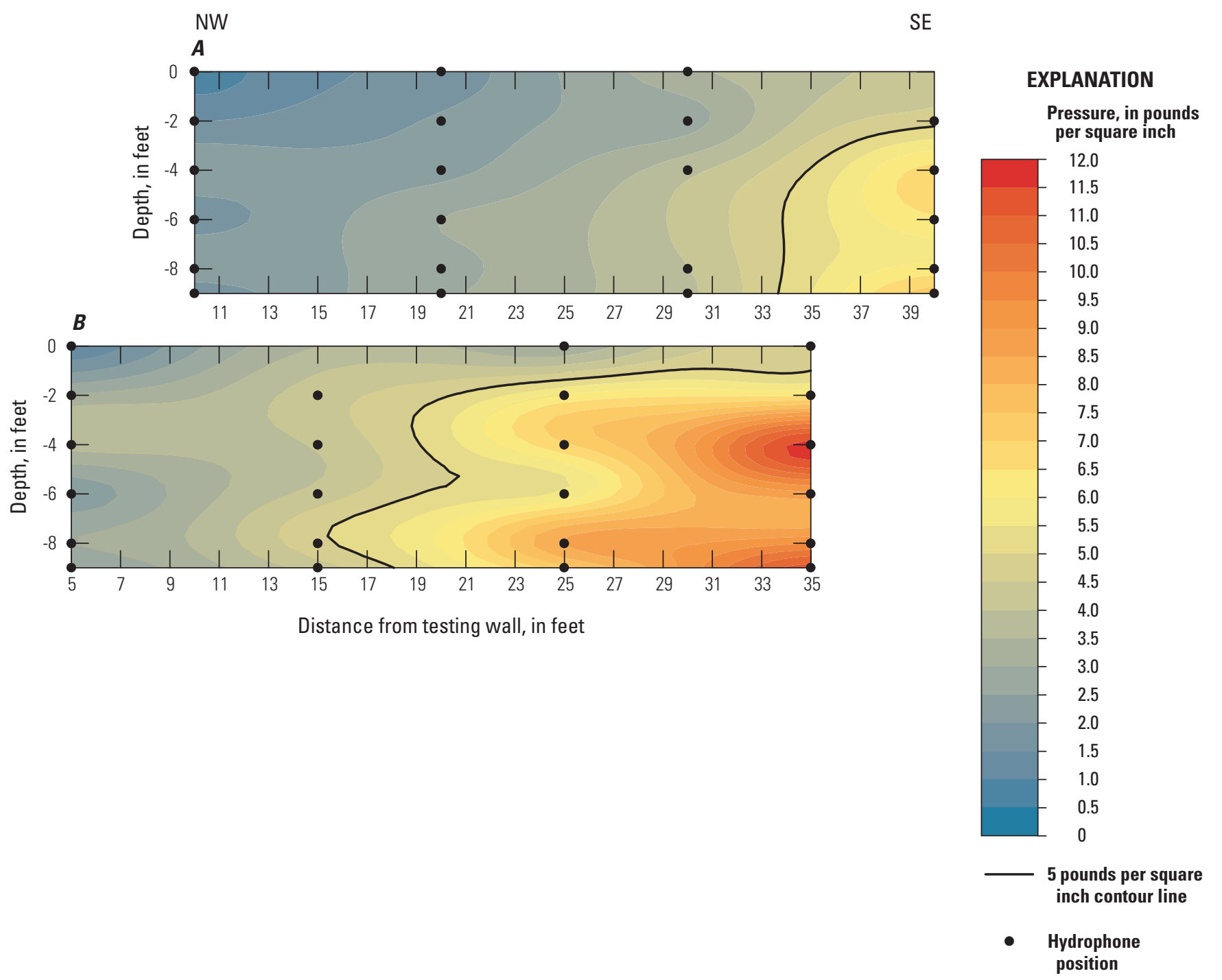

Figure 28. Spatial distribution of pressure for a single 80-cubic-inch water gun 6 feet below water surface fired at 700 pounds per square inch $(A)$, and for two 80-cubic-inch water guns 6 and 8 feet below water surface fired at 1,000 pounds per square inch $(B)$, Brandon Road study, Des Plaines River, near Joliet, Illinois.

\section{Brandon Road Ground Vibrations}

Velocities on land surface were measured using 3C geophones placed near the testing wall (figs. 5-8), and are referred to as wall velocities. Velocities in these scenarios ranged from background velocities of less than $0.005 \mathrm{in} / \mathrm{s}$ to the maximum recorded velocity of $0.239 \mathrm{in} / \mathrm{s}$. All velocities were less than the stated threshold of $0.75 \mathrm{in} / \mathrm{s}$. Directionally, the maximum velocities recorded during the experiment were $0.239 \mathrm{in} / \mathrm{s}$ of vertical velocity and $0.122 \mathrm{in} / \mathrm{s}$ of horizontal velocity.

\section{Varying Gun Distance Scenario}

This scenario was run as a series of increasing pressure tests at decreasing gun distances to determine the operational limits of the water guns in the confined space of the channel as defined by the USACE. Geophones were placed in three pairs, with one pair of R.T. Clark geophones collocated with one pair of Instantel geophones as shown in figure 5, at 0,10, and $20 \mathrm{ft}$ from the center line formed by the hydrophone boom and the gun platform at distances of 6 and $16 \mathrm{ft}$ perpendicular to the testing wall. 
Velocity generally increases linearly in all components as gun distance from the wall decreases (fig. 29). The vertical component of the geophone placed $16 \mathrm{ft}$ from the wall edge is an exception to this trend. However, the magnitude of the velocity increase is small-less than $0.01 \mathrm{in} / \mathrm{s}$ in most cases.

\section{Other Scenarios}

After the varying gun distance scenario, the water gun or guns were fixed in position relative to the testing wall (55 ft from the wall) for the remaining scenarios. Because of the repeatability of the water gun seismic signals, geophone locations were changed after sufficient data collection at each point location. The water gun or guns remained fixed spatially for most of the scenarios, allowing multiple geophone configurations for a more detailed coverage of the velocity response of the area behind the canal wall (figs. 6-8).
As shown in figure 30 , velocity from geophone locations increases linearly with water gun input pressure in all components (transverse, longitudinal, and vertical velocity components). In all shots where the water gun or guns were $55 \mathrm{ft}$ from the wall, the highest velocities were recorded on the vertical component of the geophone placed farthest from the channel, with velocity changes of $0.1 \mathrm{in} / \mathrm{s}$ occurring there. Longitudinal and transverse velocities were 50 percent or less of the vertical component velocities, and velocities for these two horizontal components were roughly equivalent between the two geophones at 6 and $16 \mathrm{ft}$ from the wall.

Differences between the 6-ft gun with gun ports aligned perpendicularly to the wall and the 8-ft gun with gun ports aligned parallel to the wall are shown in figure 31 . Varying gun depth and gun port orientation result in differences of velocity of less than 10 percent.

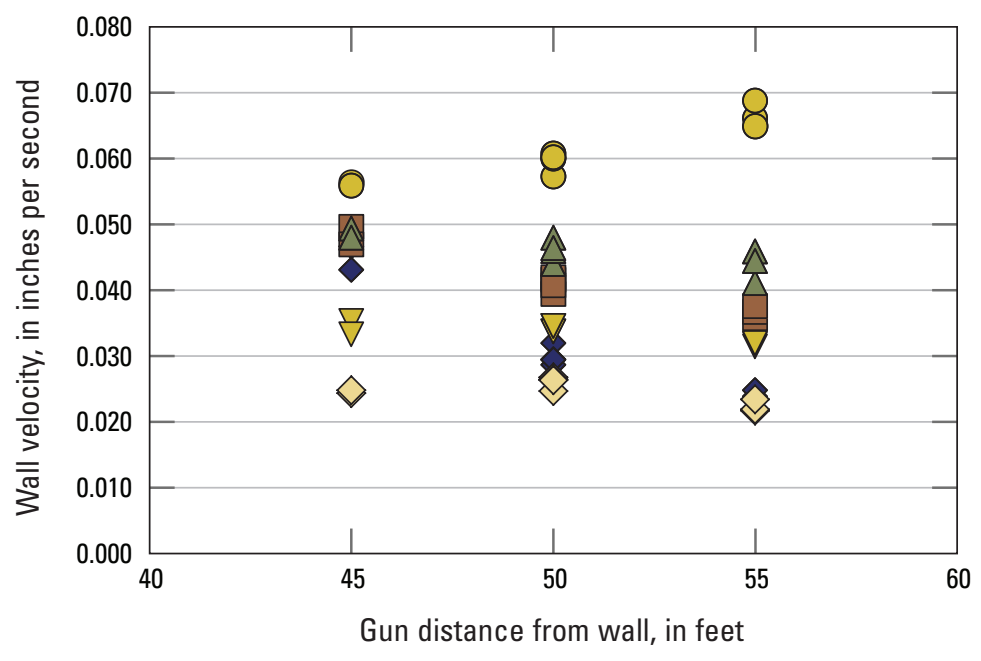

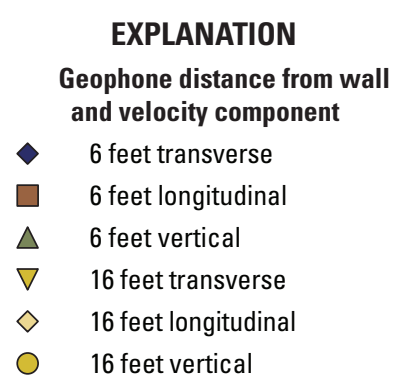

Figure 29. Changes in velocity at geophones placed 6 and 16 feet from testing wall in transverse, longitudinal, and vertical components, Brandon Road study, Des Plaines River, near Joliet, Illinois.

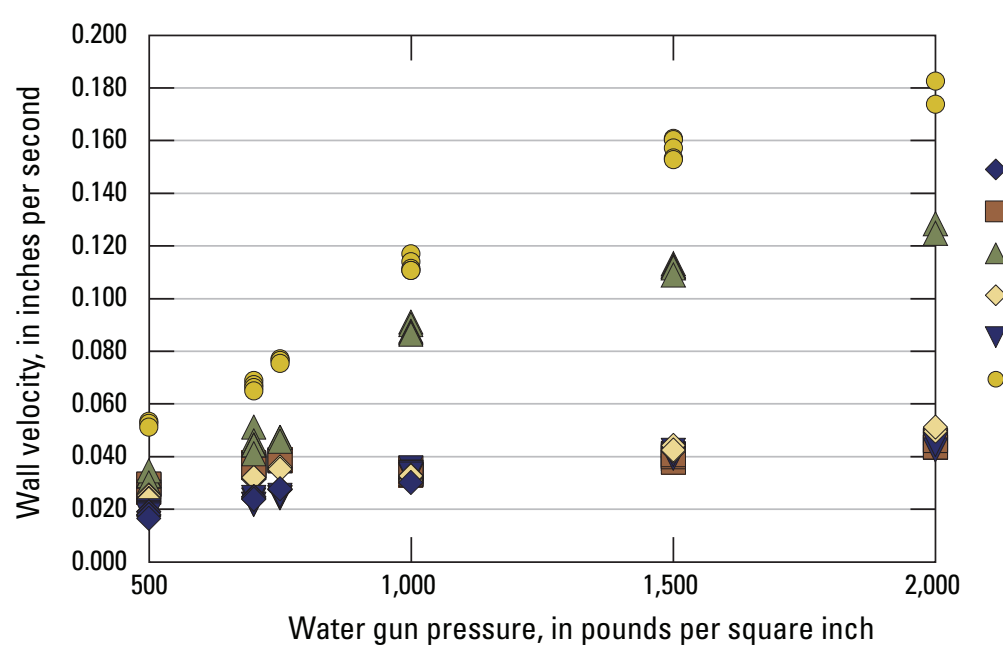

\section{EXPLANATION}

Geophone distance from wall and velocity component

6 feet transverse

6 feet longitudinal

6 feet vertical

16 feet transverse

16 feet longitudinal

16 feet vertical

Figure 30. Changes in velocity with varying water gun pressure, Brandon Road study, Des Plaines River, near Joliet, Illinois. Wall velocities in the transverse, longitudinal, and horizontal directions are shown. 
Vertical velocities decreased with distance by about 25 percent as geophones were moved from the center line out to a distance of $60 \mathrm{ft}$, as shown in figure 32. Based on a regression analysis using the three data points in figure 32 (eq. 1; coefficient of determination 0.97), the vertical component velocity is estimated to decrease to less than $0.01 \mathrm{in} / \mathrm{s}$ at a distance of $428 \mathrm{ft}$ along the wall. Transverse and longitudinal velocities do not show a defined trend, with longitudinal velocities varying by less than 10 percent and transverse velocities fluctuating with no defined trend.

$$
Y=0.0852 e^{-0.005 X}
$$

where

$Y \quad$ is the value of wall velocity in inches per second, $x \quad$ is the horizontal distance along the wall in feet, and

$e \quad$ is the natural logarithm.

Differences in velocity at distances of 6 and 16 feet inland from the wall from firing a single water gun compared to two water guns are shown in figure 33. Adding a second gun and firing at the same pressure results in an increase in velocity of the wall, with the proportion of increase varying by directional component. The vertical component increased by 60 percent compared to a single gun firing. The horizontal components (longitudinal and transverse) show a smaller amount of increase from the second gun, but vary with the location of the geophone in relation to distance from the edge of the wall.
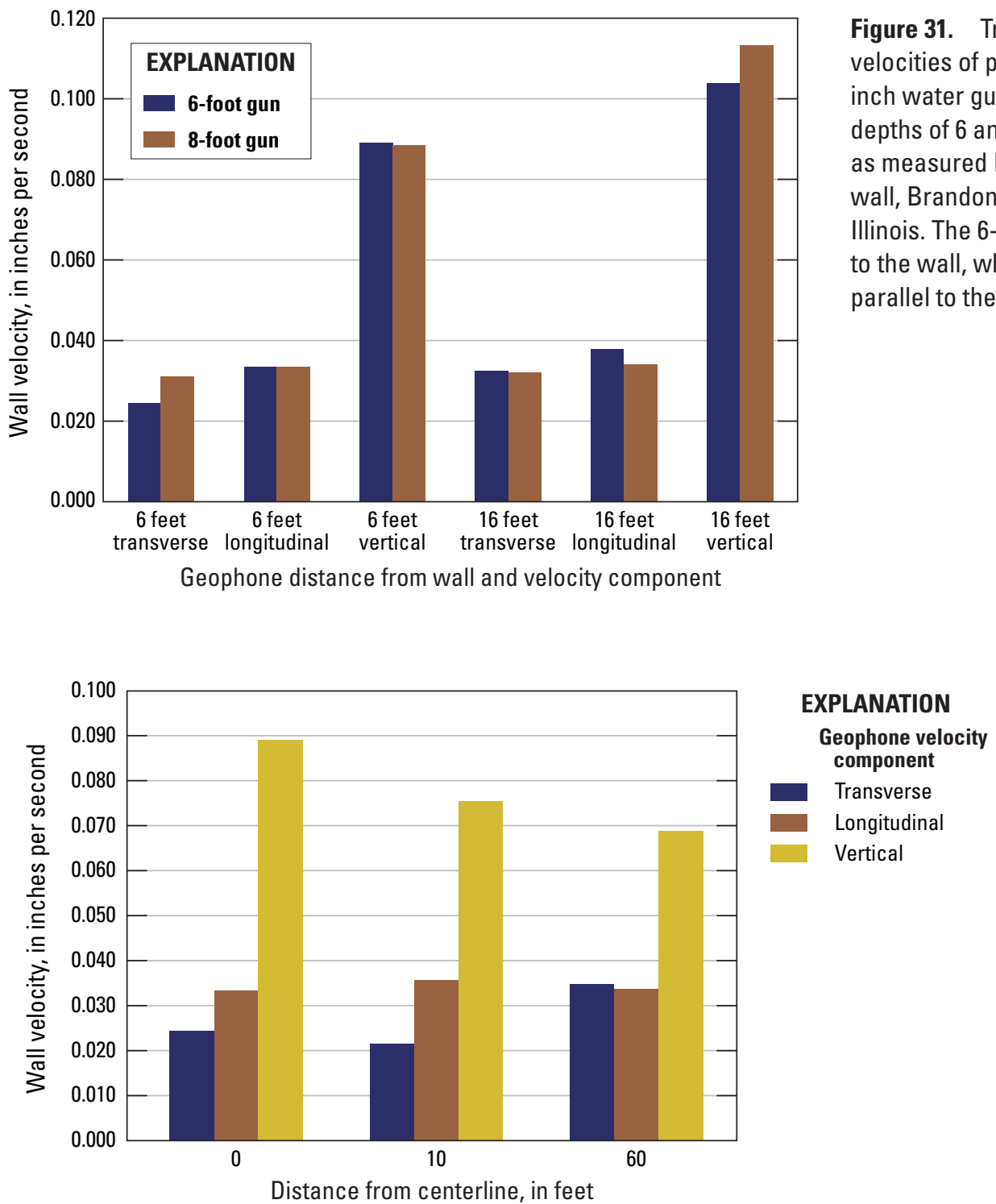

Figure 31. Transverse, longitudinal, and vertical wall velocities of pressure waves from firing of two 80-cubicinch water guns fired at 1,000 pounds per square inch at depths of 6 and 8 feet below water surface, respectively, as measured by geophones 6 and 16 feet inland from wall, Brandon Road study, Des Plaines River, near Joliet, Illinois. The 6 -foot gun had ports aligned perpendicular to the wall, whereas the 8-foot gun had ports aligned parallel to the wall.

\author{
Figure 32. Transverse, longitudinal, \\ and vertical wall velocities of \\ pressure waves from firing of two \\ 80 -cubic-inch water guns at 6 \\ and 8 feet below water surface, \\ respectively, as measured by three \\ three-component geophones placed \\ 6 feet from edge of channel at \\ various offsets from the center line \\ of experiment, Brandon Road study, \\ Des Plaines River, near Joliet, Illinois.
}




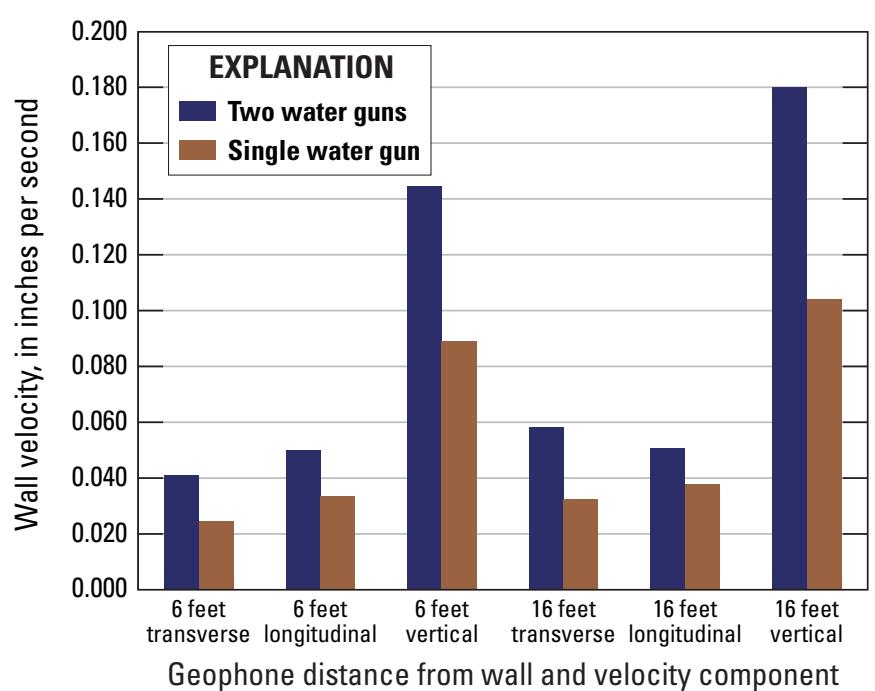

Figure 33. Transverse, longitudinal, and vertical wall velocities of pressure waves from firing of a single 80 -cubic-inch water gun and two 80-cubic-inch water guns at depths of 6 and 8 feet below water surface, respectively, and all fired at 1,000 pounds per square inch, as measured by geophones 6 and 16 feet inland from wall, Brandon Road study, Des Plaines River, near Joliet, Illinois.

\section{Acceleration}

Acceleration data were collected by two singlecomponent accelerometers mounted on top of the canal wall. Accelerometer positions remained fixed. Acceleration rates ranged from 0.0002 to $0.0188 \mathrm{ft} / \mathrm{s}^{2}$ over the duration of the experiment. The maximum acceleration rates recorded were $0.0188 \mathrm{ft} / \mathrm{s}^{2}$ in an upward direction, and the maximum horizontal acceleration was $0.0123 \mathrm{ft} / \mathrm{s}^{2}$ in a direction towards the channel (out of the canal wall).

Change in acceleration as the gun input pressure changes are shown in figure 34 . These graphs are a combination of data collected over the entire setup that used a single water gun at a depth of $6 \mathrm{ft}$ bws. Five water gun shots were taken at each point location. For each shot, the maximum value was recorded. The arithmetic mean of the five maximum values was used to generate the figures in this report. Processed location data were integrated with the average maximum values recorded by the accelerometers. For both components, the acceleration increases with increasing gun pressure.

\section{Lemont Water Pressure}

\section{Replicate Scenario}

In this scenario, we evaluated the operational limits of the water guns in the CSSC by decreasing distances between the water gun or guns and the canal testing wall. Pressure data were collected on two hydrophone strings (18 hydrophones total) suspended from two buoys at distances of 5 and $15 \mathrm{ft}$ from the wall. Water guns were set at depths of 4 and $14 \mathrm{ft}$ and fired separately, and then both water guns were fired simultaneously. Water guns originally were set at $90 \mathrm{ft}$ from the testing wall and moved in $10-\mathrm{ft}$ increments until they were $40 \mathrm{ft}$ from the testing wall.

Variations in pressure as monitored by three representative hydrophones at depths of 4, 14, and $22 \mathrm{ft}$ bws on the buoy mounted $5 \mathrm{ft}$ from the testing wall are shown in figure 35. All hydrophone depths show a similar trend of linearly increasing pressure as the water guns approach the wall at $40 \mathrm{ft}$. Pressure then decreases at $30 \mathrm{ft}$ for the 14- and 22-ft hydrophones, but continues to increase for the 4-ft hydrophone. Factors that could cause this change include distance to wall boundary conditions or asymmetry of the pressure field immediately surrounding the gun.

Pressures from the 22-ft hydrophone are higher than pressures from the 4- and 14-ft hydrophones from 90- to $40-\mathrm{ft}$ distances and for all configurations. Data collected at $30 \mathrm{ft}$ indicate a decrease in pressure from the 22-ft and 14-ft hydrophones relative to previous data collected at $40 \mathrm{ft}$ in contrast to a general decrease in pressures with greater distance from the testing wall. The pressures for the 4-ft hydrophone at $30 \mathrm{ft}$ are lower or higher relative to the $22-\mathrm{ft}$ hydrophone data, depending on operations of the water guns. The pressures for the 14-ft hydrophone are slightly higher than pressures for the $4 \mathrm{ft}$ hydrophone at distances of $40 \mathrm{ft}$ and greater, but are less at a distance of $30 \mathrm{ft}$.

At a distance of greater than $40 \mathrm{ft}$, the magnitudes of the pressures from two guns (fig. 35A) and the 14-ft gun (fig. 35C) are similar ( $<10$ percent variation). Pressures from the 4 -ft gun (fig. 35B) are 10-15 percent lower at each distance compared to either the two guns or the $14-\mathrm{ft}$ gun. The $5-\mathrm{lb} / \mathrm{in}^{3}$ threshold was reached at all three hydrophone depths when the water gun was $60 \mathrm{ft}$ from the wall during the firing of both guns together and also during the firing of the 14-ft single gun. However, the 4-ft single gun reached the $5 \mathrm{lb} / \mathrm{in}^{3}$ threshold when the water gun was $50 \mathrm{ft}$ from the wall. 


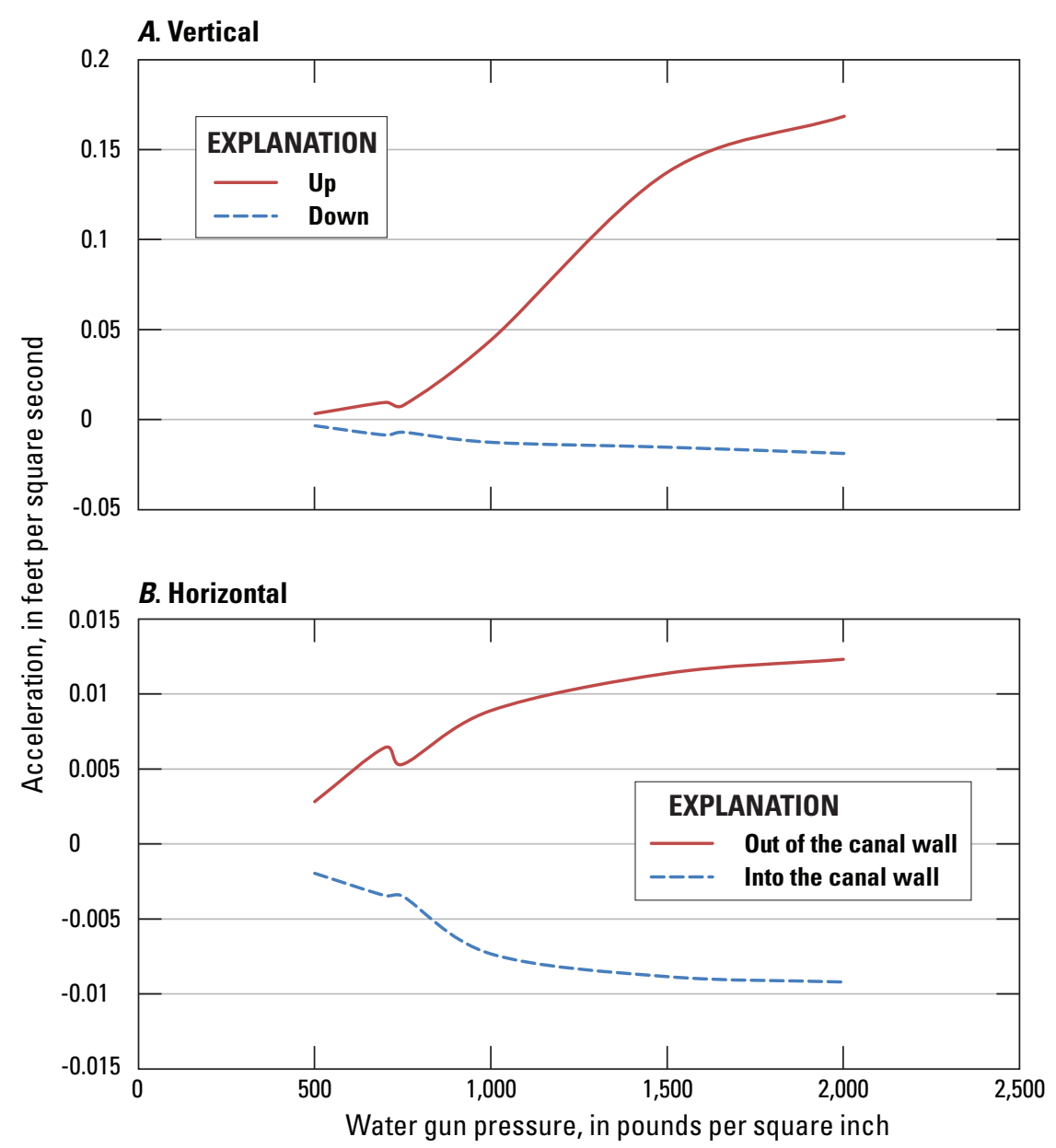

Figure 34. Acceleration of pressure wave velocities as water gun input pressure increases in vertical $(A)$ and horizontal $(B)$ directions, Brandon Road study, Des Plaines River, near Joliet, Illinois. 


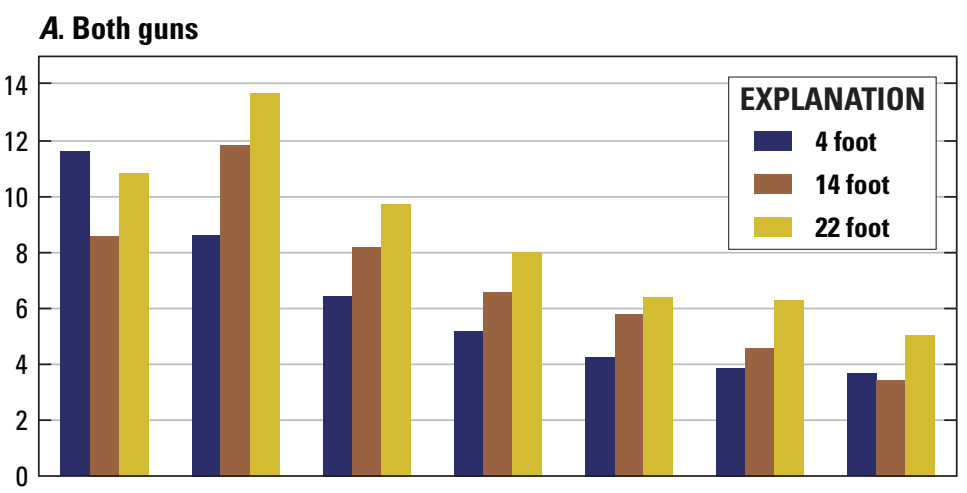

B. 4-foot gun/gun 2

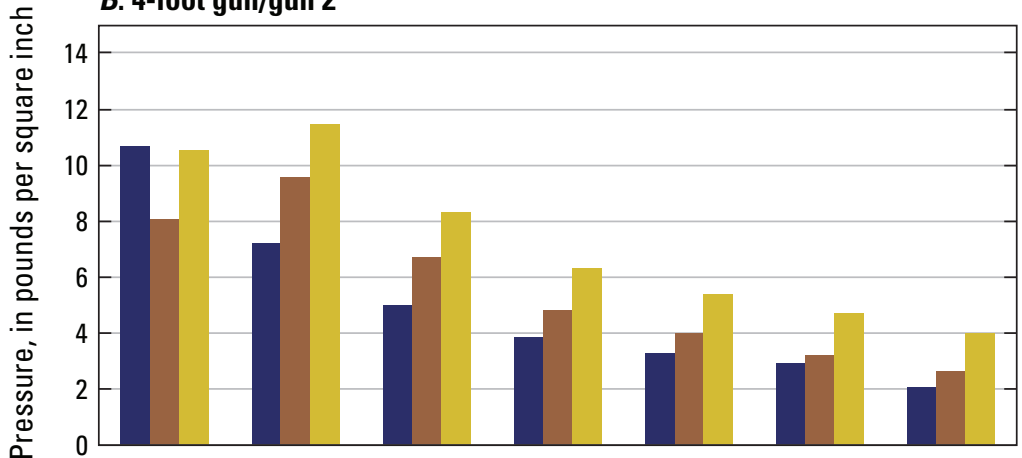

C. 14-foot gun/gun 1

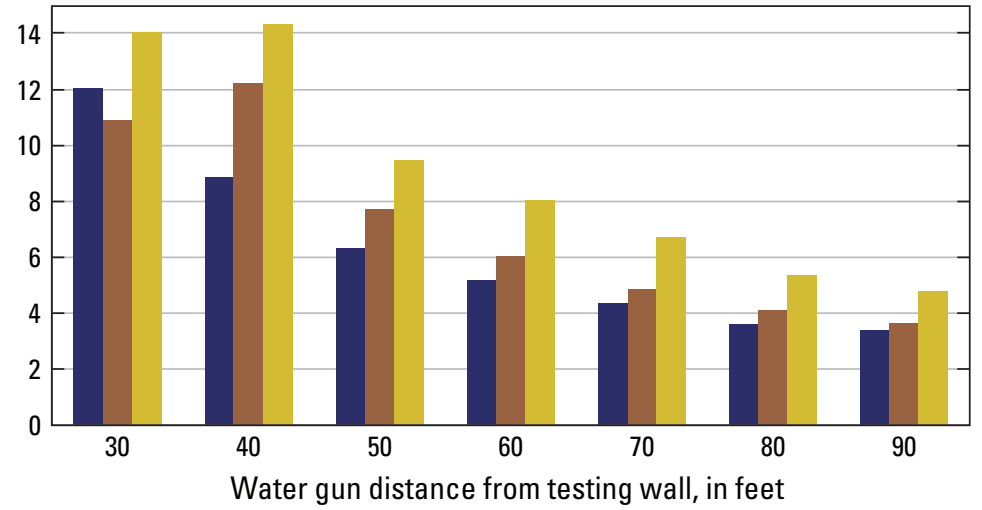

Figure 35. Pressure measurements at depths of 4,14 , and 22 feet below water surface from two 80 -cubic-inch water guns $(A)$, a single 80 -cubic-inch water gun suspended at a depth of 4 feet below water surface $(B)$, and a single 80 -cubic-inch water gun suspended at a depth of 14 feet below water surface $(C)$, and all fired at 2,000 pounds per square inch at distances of 30 to 90 feet from the testing wall, Chicago Sanitary Ship Channel, near Lemont, Illinois.

\section{Double Gun Grid Scenario}

The double gun grid scenario involved recording pressures surrounding two 80 -in ${ }^{3}$ water guns placed at distances of $40 \mathrm{ft}$ and $120 \mathrm{ft}$, respectively, from the north wall. Both water guns were set at a depth of $14 \mathrm{ft}$ bws. The first trial collected data at a gun input pressure of 2,000 lb/in ${ }^{2}$. Pressure data were collected from the firing of one water gun, and then from the simultaneous firing of two water guns.
Pressure maps for three separate depths (figs. 36-41) show variations for depth above, below, and at the level of the water guns. The $5-\mathrm{lb} / \mathrm{in}^{2}$ threshold pressure extended across most of the measured area, with depths below the water gun depth showing the greatest radial pressure extent encompassing the entire measured area. Pressures decrease with increasing radius from the water gun location. Pressures at $14 \mathrm{ft}$ (gun depth) were lower than pressures recorded either near the surface or at the bottom of the canal. This change in the shape of the pressure may be caused by a more spatially extensive environment. 


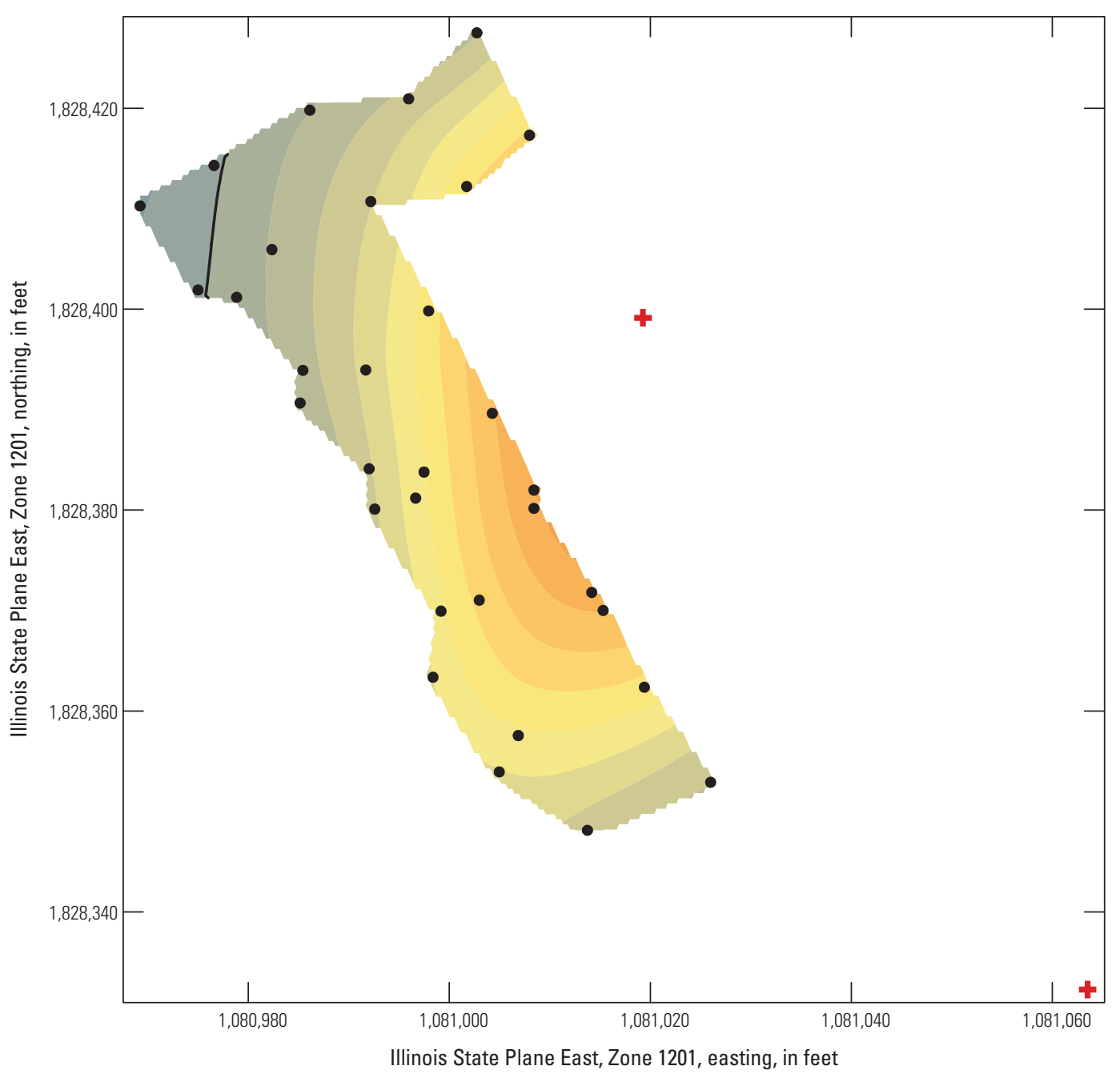

\section{EXPLANATION}

Pressure, in pounds per square inch

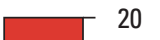

$-19$

18

$-17$

$-16$

$-15$

$-14$

$-13$

$-12$

$-11$

$-10$

$-9$

$-8$

8
$-\quad 7$

6
$-\quad 5$

5
$-\quad 4$

$-3$

$-2$

10

5 pounds per square inch contour line

$+\quad$ Water gun

- Hydrophone group position

Figure 36. Pressure measurements at a depth of 6 feet below water surface from a single 80-cubic-inch water gun fired at 2,000 pounds per square inch, Chicago Sanitary Ship Channel, near Lemont, Illinois. 


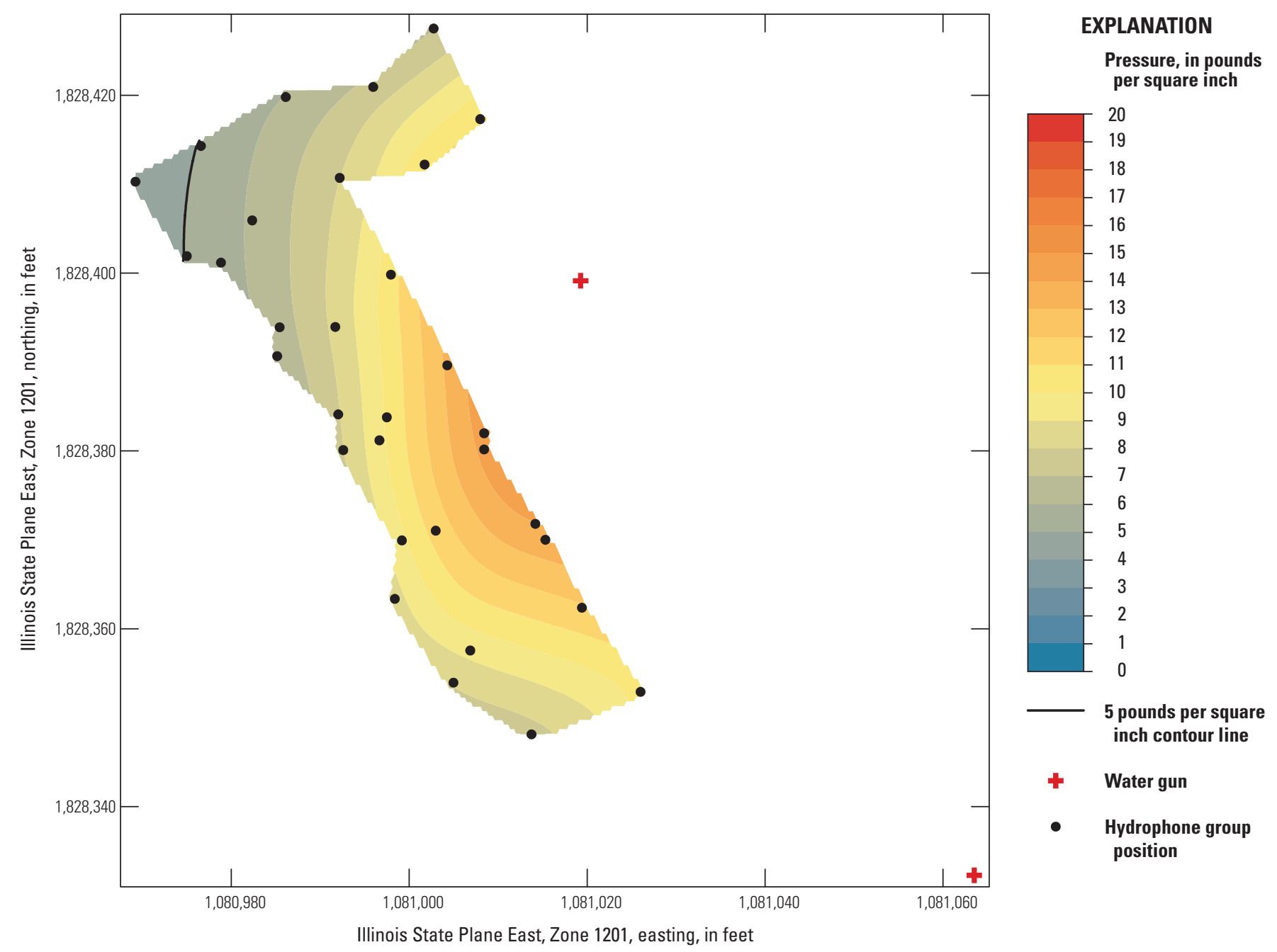

Figure 37. Pressure measurements at a depth of 6 feet below water surface from two 80-cubic-inch water guns both fired at 2,000 pounds per square inch, Chicago Sanitary Ship Channel, near Lemont, Illinois. 


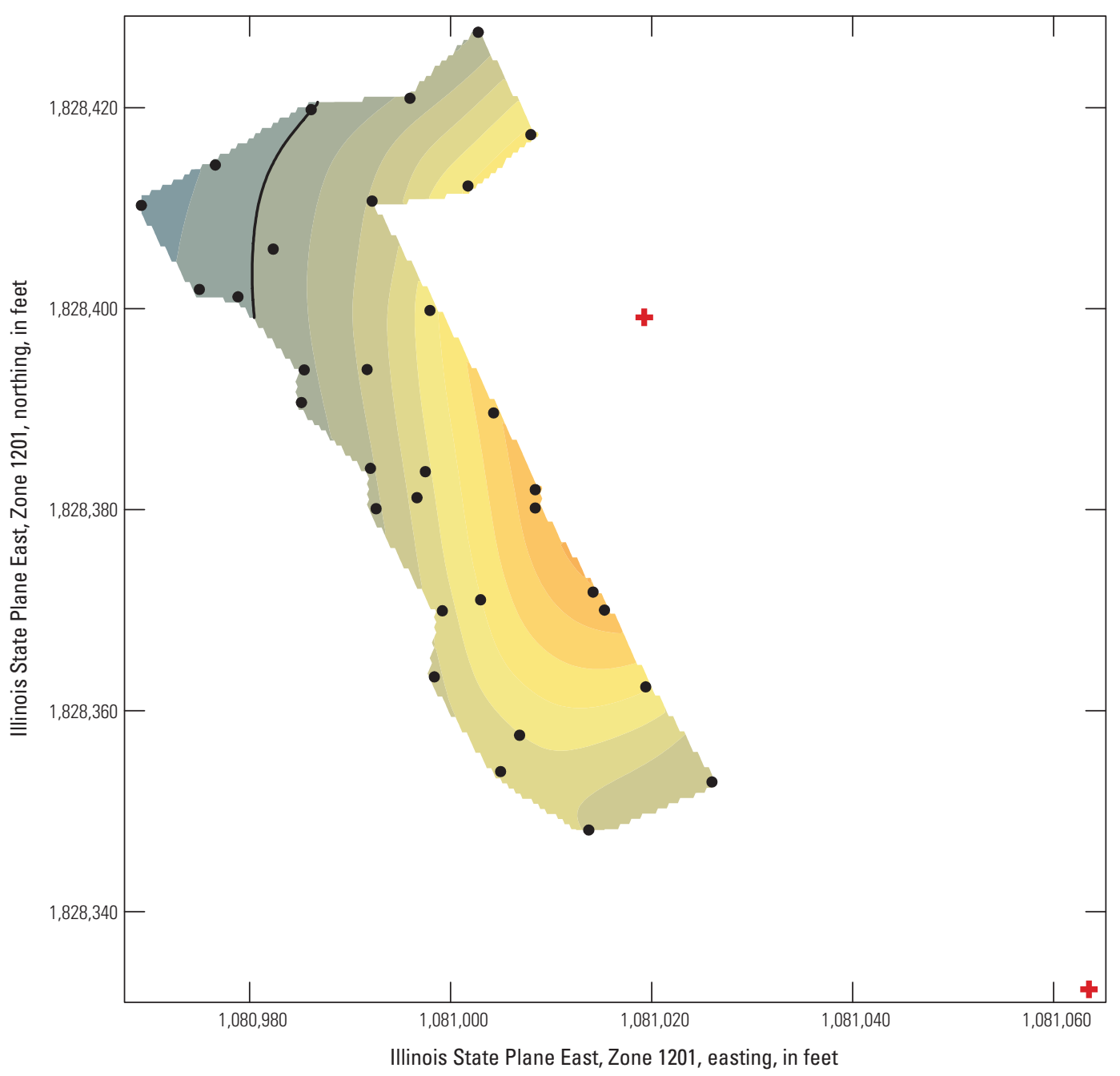

\section{EXPLANATION}

Pressure, in pounds per square inch

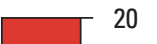

20
$-\quad 19$

18

$-17$

$-16$

$-15$

$-14$

$-13$

$-12$

$-11$

$-10$

$-\quad 9$
$-\quad 8$

$-\quad 8$
$-\quad 7$

$\begin{array}{r}8 \\ -\quad 7 \\ \hline\end{array}$

6
$-\quad 5$

5
$-\quad 4$

$-3$

$-2$

1
$-\quad 0$

5 pounds per square inch contour line

$+\quad$ Water gun

- Hydrophone group position

Figure 38. Pressure measurements at a depth of 14 feet below water surface from a single 80 -cubic-inch water gun fired at 2,000 pounds per square inch, Chicago Sanitary Ship Channel, near Lemont, Illinois. 


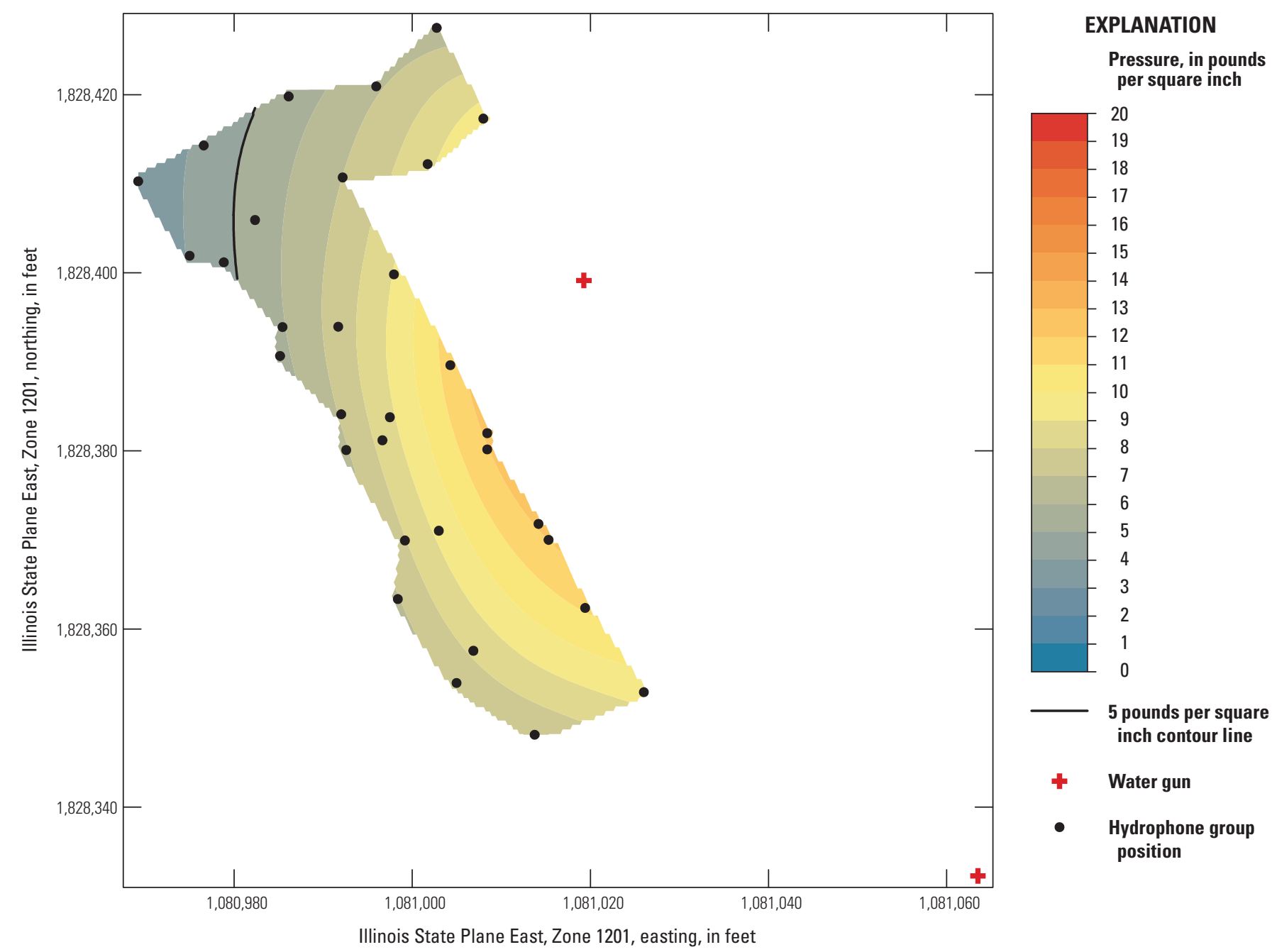

Figure 39. Pressure measurements at a depth of 14 feet below water surface from two 80-cubic-inch water guns both fired at 2,000 pounds per square inch, Chicago Sanitary Ship Channel, near Lemont, Illinois. 

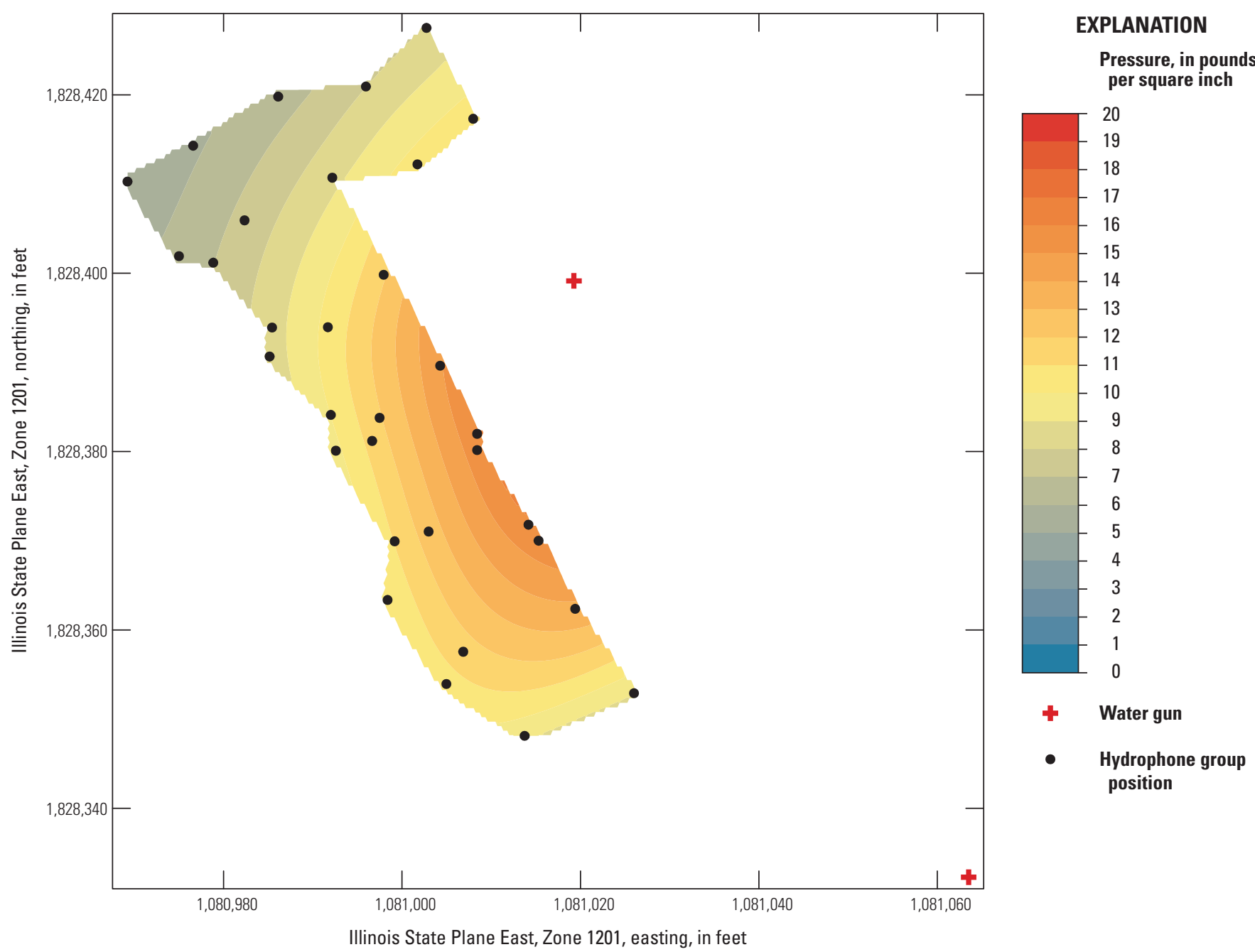

Figure 40. Pressure measurements at a depth of 22 feet below water surface from a single 80 -cubic-inch water gun fired at 2,000 pounds per square inch, Chicago Sanitary Ship Channel, near Lemont, Illinois. 


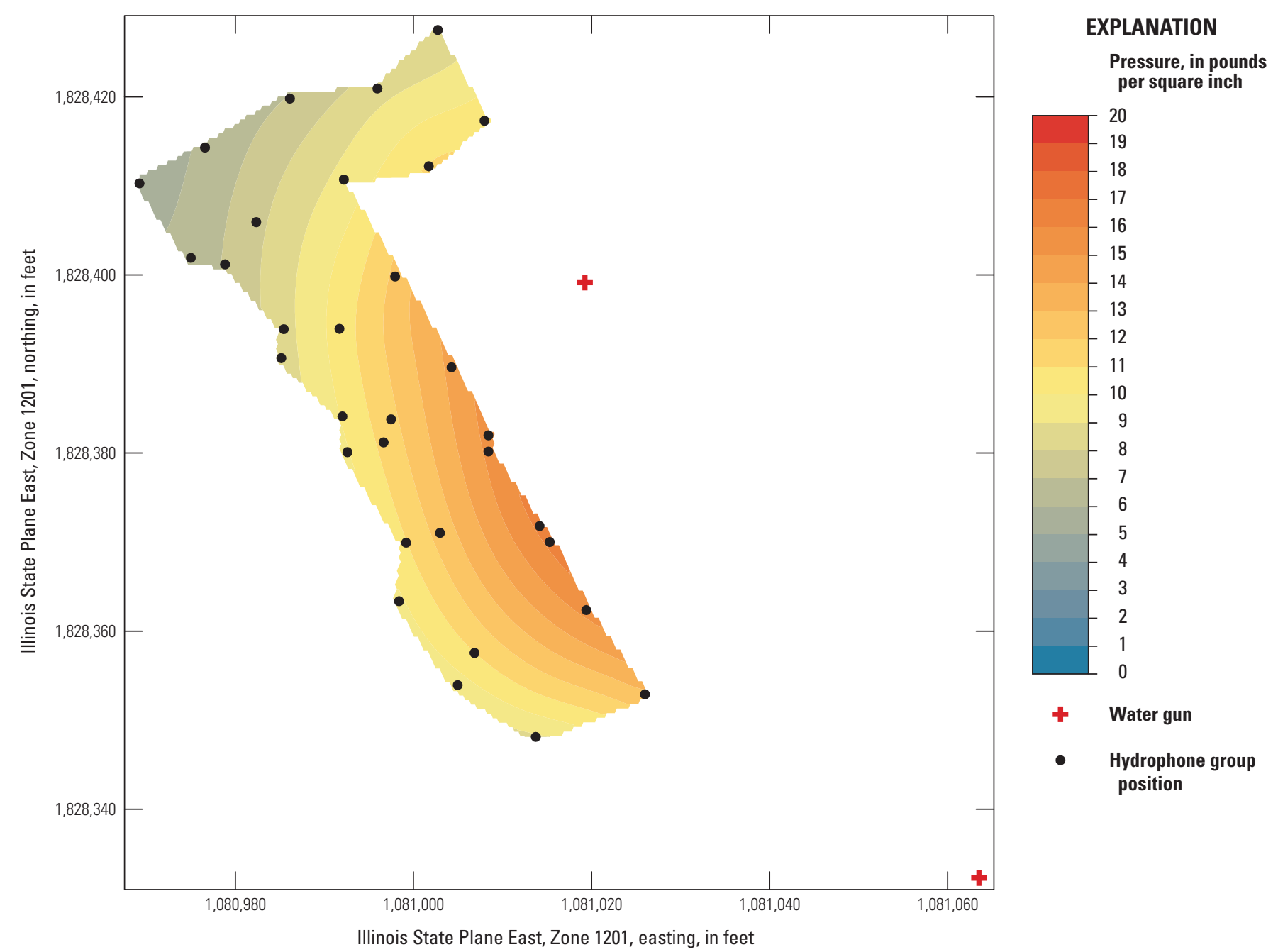

Figure 41. Pressure measurements at a depth of 22 feet below water surface from two 80 -cubic-inch water guns both fired at 2,000 pounds per square inch, Chicago Sanitary Ship Channel, near Lemont, Illinois.

There was not a very noticeable difference in the canal pressure fields between firing one and both water guns. The magnitude of differences at all depths between two water guns and a single, 14-ft water gun was 5 and 10 percent-similar to the 2011 replicate scenario.

The second trial was done with a lower gun input pressure $\left(1,000 \mathrm{lb} / \mathrm{in}^{2}\right)$ than the first trial $\left(2,000 \mathrm{lb} / \mathrm{in}^{2}\right.$. Pressure data were collected from firing two 80 -in ${ }^{3}$ water guns placed in the same linear configuration $40 \mathrm{ft}$ and $120 \mathrm{ft}$ from the testing wall, with the guns set at a depth of $14 \mathrm{ft}$ bws.

The results from this trial (figs. 42-47) indicated trends similar to those of the double gun grid high pressure trial: The largest pressures were below the gun depth, and pressures from $14 \mathrm{ft}$ bws (the gun depth) were lower than pressures from above (6 ft bws) or below (22 ft bws) the gun depth. A generally radial pattern with pressure decreasing away from the water gun location is indicated for all data collected. In the low pressure trial, the $5 \mathrm{lb} / \mathrm{in}^{2}$ threshold pressure was not exceeded at any location on any of the pressure maps, in contrast to the high pressure trial, in which the threshold pressure was exceeded at most locations. There was a large disparity in the radius of the $5 \mathrm{lb} / \mathrm{in}^{2}$ zone between the high and low pressure trials, as well as a clearer distinction between single gun firings and double gun firings during the low pressure trial that was not observed in the high pressure trial. This indicates that water gun input pressure likely plays a larger role in determining the extent of the water gun pressure field in this environment than the configuration of single or double guns. 


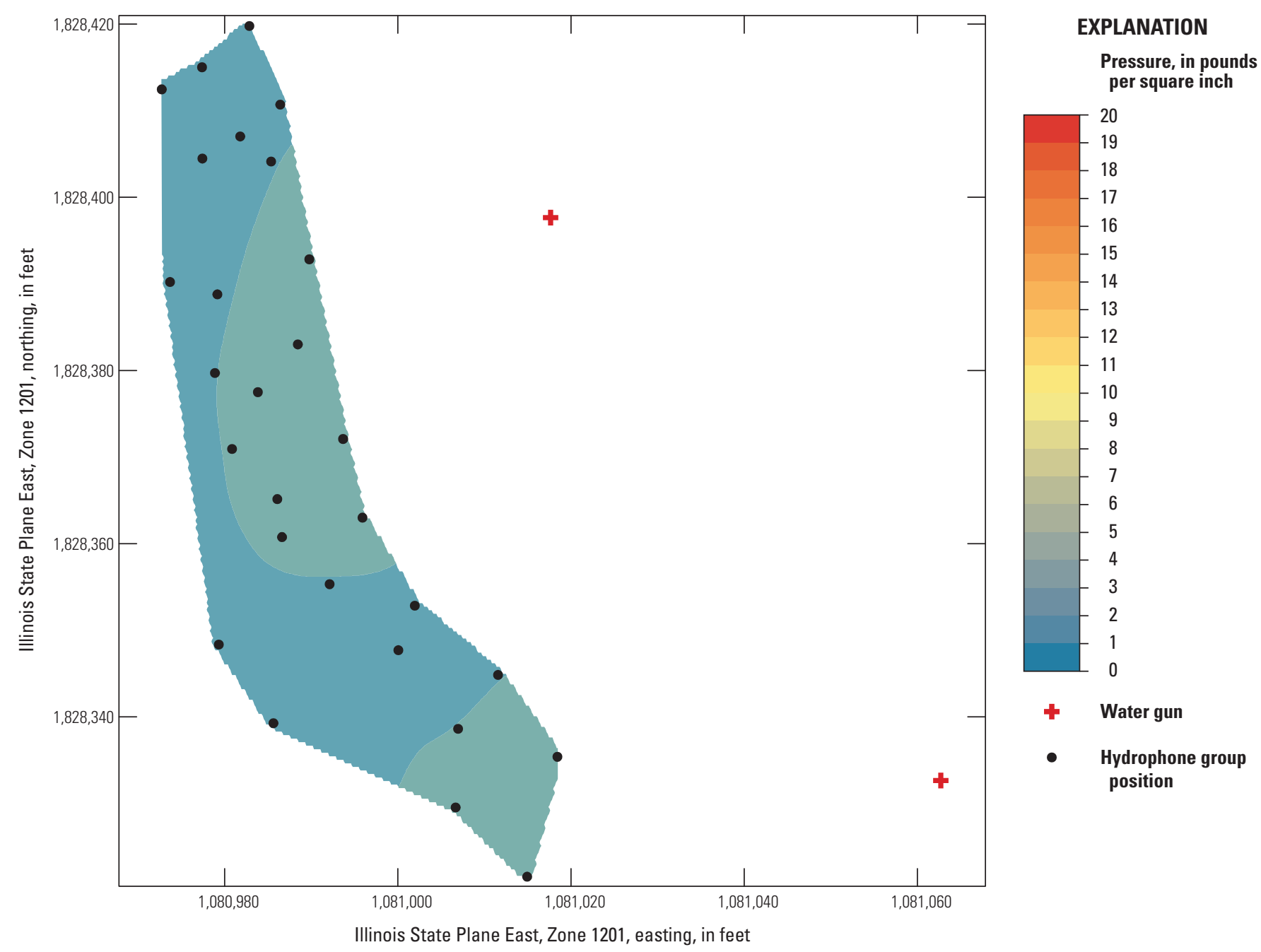

Figure 42. Pressure measurements at a depth of 6 feet below water surface from a single 80-cubic-inch water gun fired at 1,000 pounds per square inch, Chicago Sanitary Ship Channel, near Lemont, Illinois. 


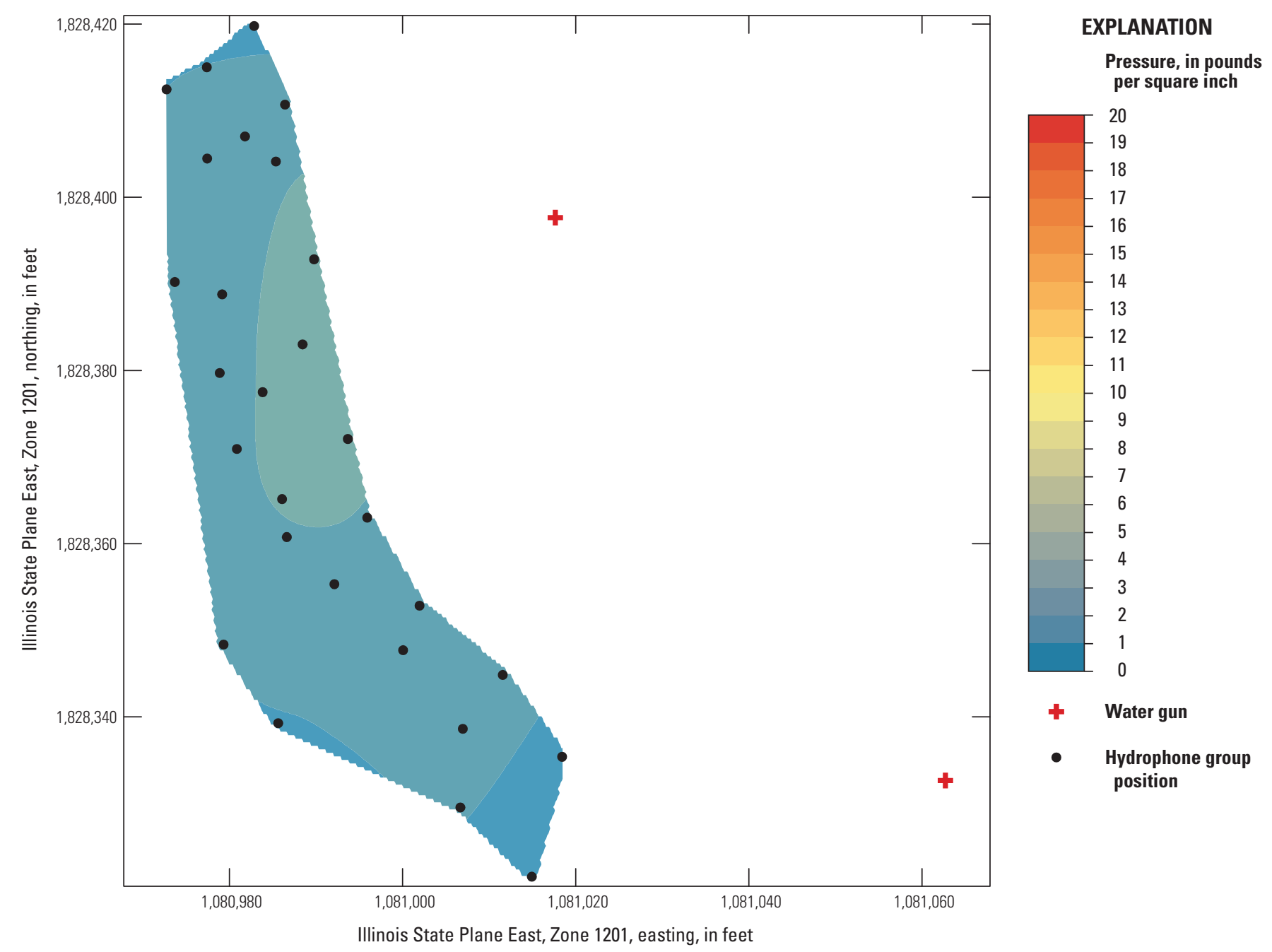

Figure 43. Pressure measurements at a depth of 6 feet below water surface from two 80-cubic inch water guns both fired at 1,000 pounds per square inch, Chicago Sanitary Ship Channel, near Lemont, Illinois. 


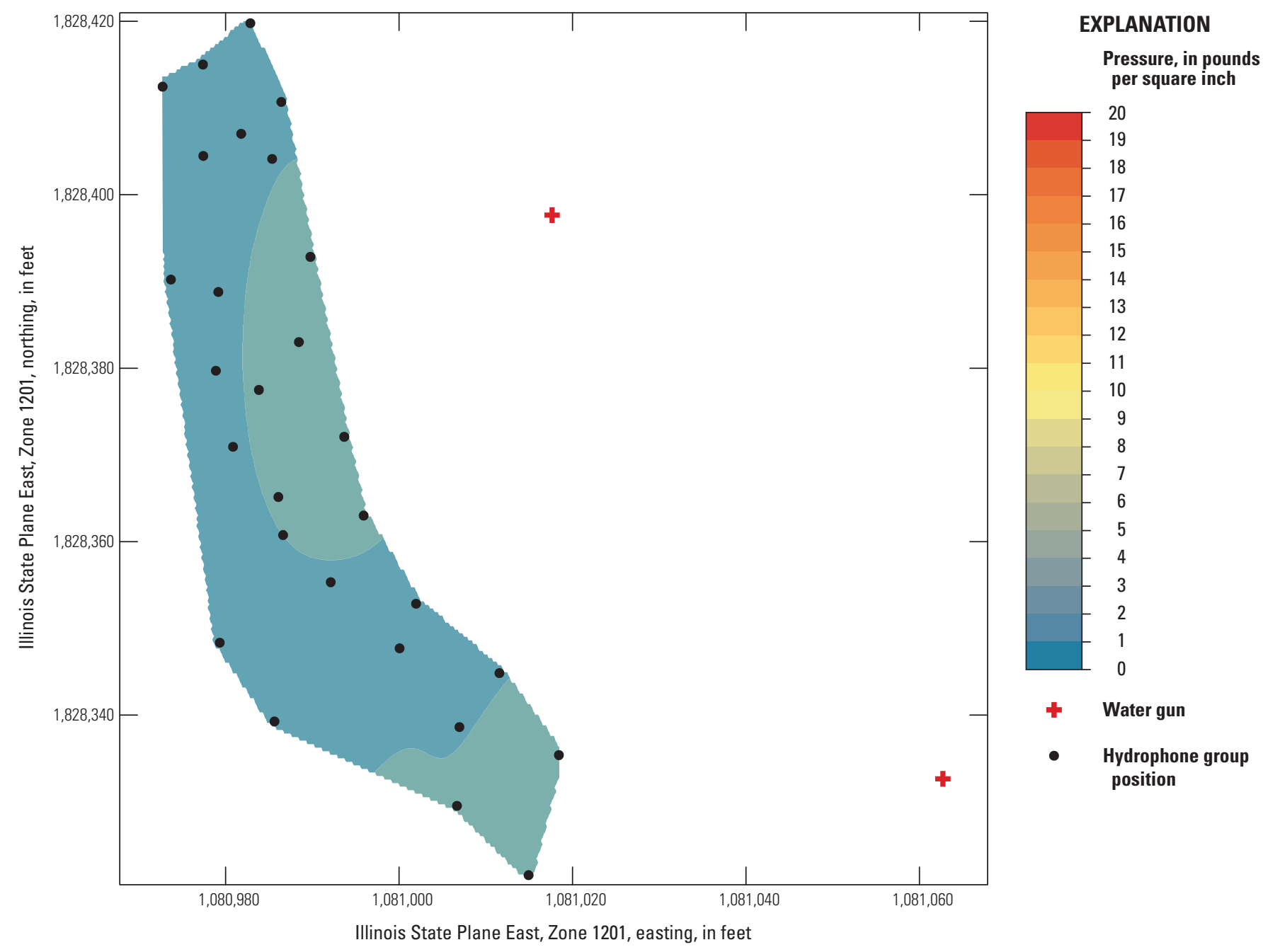

Figure 44. Pressure measurements at a depth of 14 feet below water surface from a single 80-cubic-inch water gun fired at 1,000 pounds per square inch, Chicago Sanitary Ship Channel, near Lemont, Illinois. 


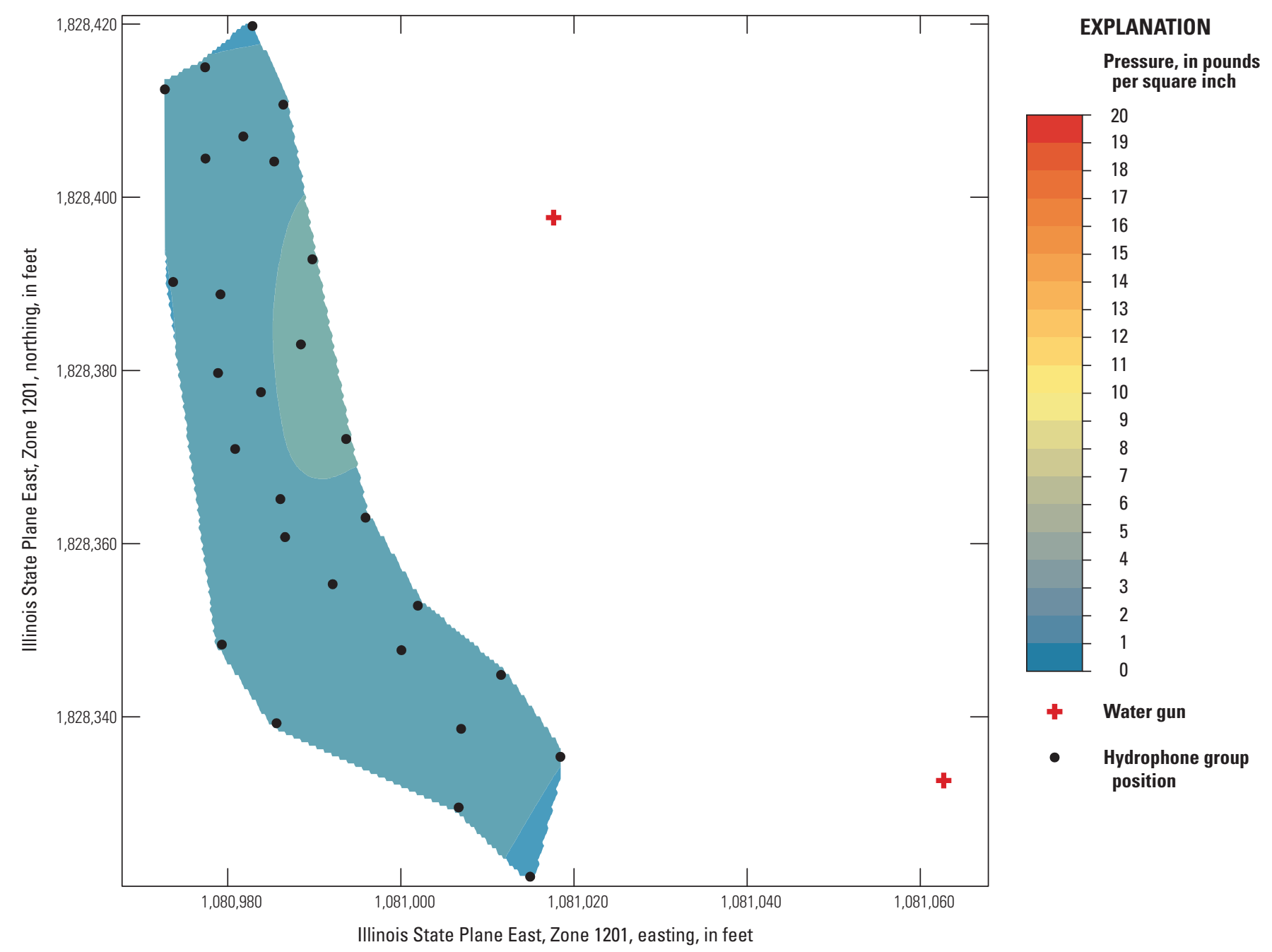

Figure 45. Pressure measurements at a depth of 14 feet below water surface from two 80-cubic-inch water guns fired at 1,000 pounds per square inch, Chicago Sanitary Ship Channel, near Lemont, Illinois. 


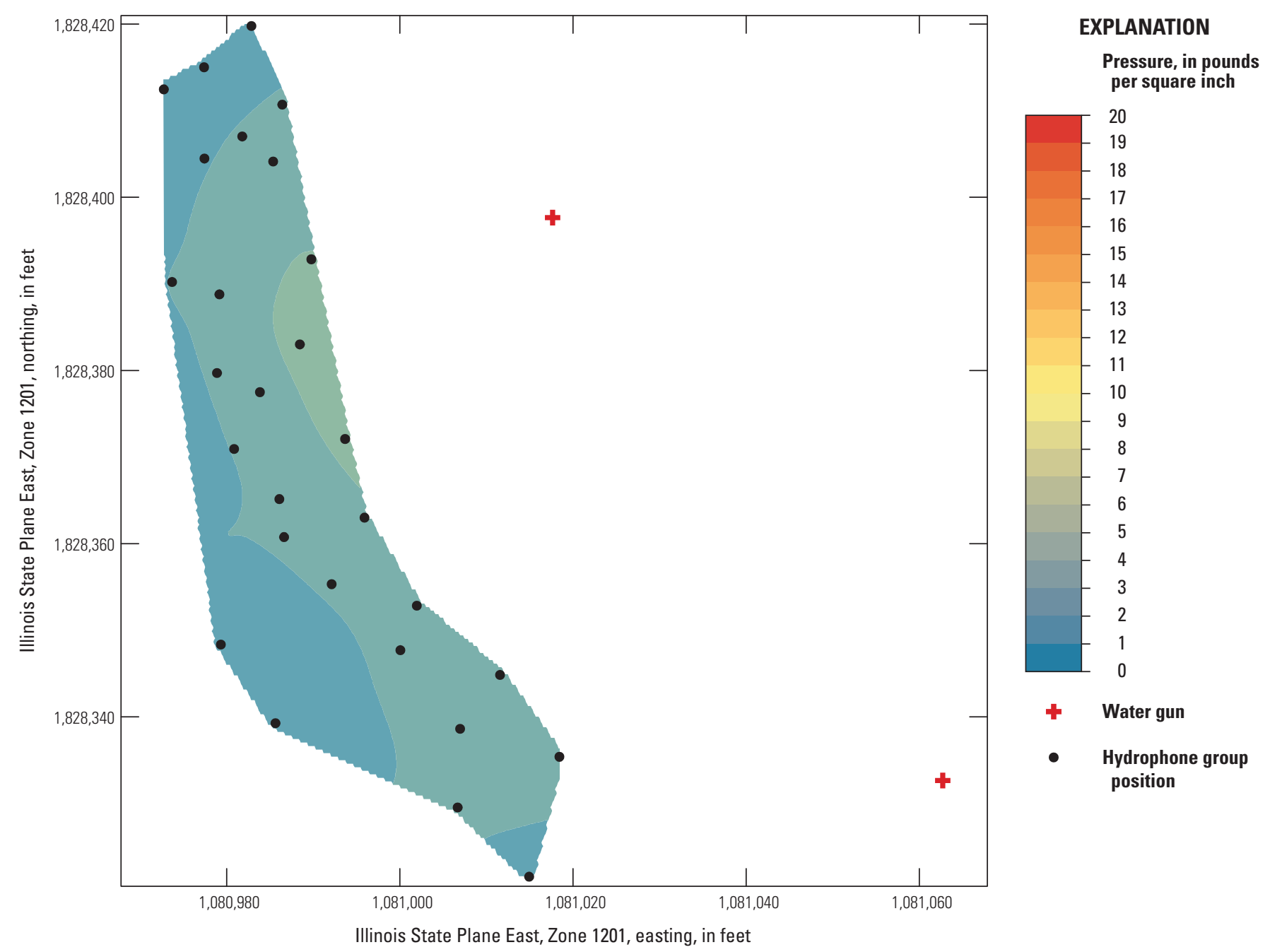

Figure 46. Pressure measurements at a depth of 22 feet below water surface from a single 80-cubic-inch water gun fired at 1,000 pounds per square inch, Chicago Sanitary Ship Channel, near Lemont, Illinois. 


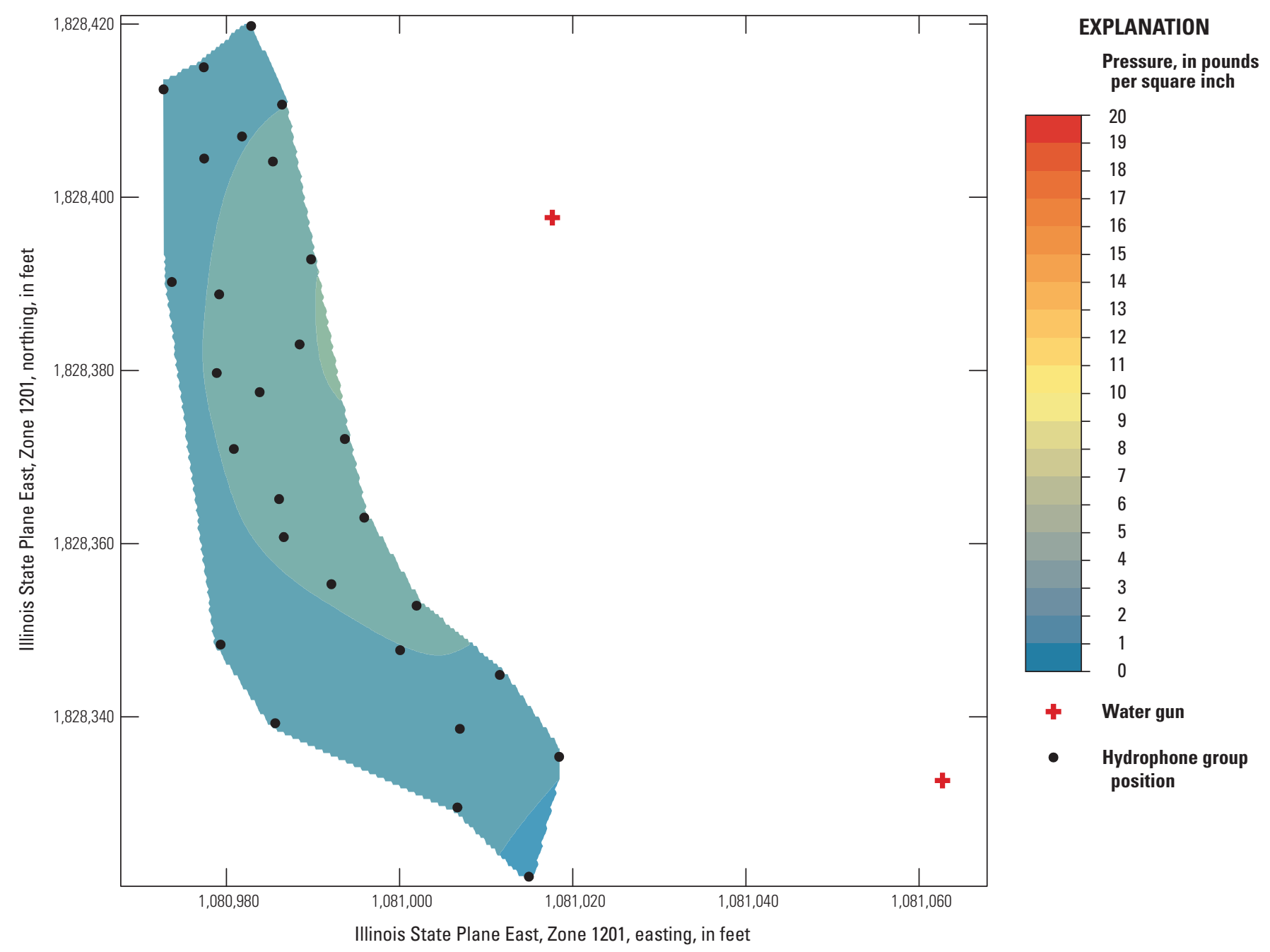

Figure 47. Pressure measurements at a depth of 22 feet below water surface from two 80 -cubic-inch water guns both fired at 1,000 pounds per square inch, Chicago Sanitary Ship Channel, near Lemont, Illinois.

\section{Lemont Ground Vibrations}

Velocity was measured using surface three-component geophones, as at Brandon Road. Additionally, velocity was measured using three-component downhole geophones. Geophones were placed 5, 35, and $100 \mathrm{ft}$ away from the canal wall for the 2011 replicate scenario, and 5 and $15 \mathrm{ft}$ away from the canal wall for the double gun grid scenario. In the double gun grid scenario, geophones were placed in line and offset from the center line. The surface geophones were oriented such that the longitudinal component of each geophone case was pointing directly away from the canal, perpendicular to the walls.
Velocities in both scenarios ranged from background velocities of less than $0.005 \mathrm{in} / \mathrm{s}$ to the maximum recorded velocity of $0.304 \mathrm{in} / \mathrm{s}$. All velocities were less than the stated sensitive machinery limit threshold of $0.75 \mathrm{in} / \mathrm{s}$. Directionally, the maximum velocities recorded were $0.304 \mathrm{in} / \mathrm{s}$ in the vertical component and $0.122 \mathrm{in} / \mathrm{s}$ in the horizontal component.

\section{Replicate Scenario}

This scenario involved collecting data with decreasing distance from the water gun to the canal wall to determine how velocity measured near the canal wall changed as water gun distance decreased. Velocity data were collected by 
downhole (at depths of $5 \mathrm{ft}$ [shallow] and 20-25 ft [deep] bgs) and surface geophones. The geophones were placed at the borehole locations 5 and $35 \mathrm{ft}$ from the canal in a transect about $15 \mathrm{ft}$ downstream of the water gun center line (fig. 9A).

The surface geophone placed $5 \mathrm{ft}$ landward from the right bank canal wall recorded larger velocities at each water gun depth and double gun shot compared to the surface geophone placed $35 \mathrm{ft}$ landward from the canal wall (fig. 48). This velocity trend also is present in the borehole geophones. The 5-ft borehole geophones recorded higher vertical component velocities than the $35-\mathrm{ft}$ borehole geophones during single and double gun shots. Surface velocities generally are higher than borehole velocities because the boreholes are confined by rock on all sides, making movement more difficult. The deep borehole geophones recorded higher velocities than the shallow borehole geophones (fig. 49). This velocity difference is more pronounced at the 5 -ft borehole and decreases as distance from the water gun increases. The deep geophones likely have higher velocities than the shallow borehole geophones because the deep borehole geophones are placed at relatively the same elevation as the water gun placed $14 \mathrm{ft}$ bws - closer than the shallow borehole geophone.

There also is a change in which component (transverse, longitudinal, or vertical) recorded the highest velocity. At the surface geophone placed $5 \mathrm{ft}$ from the canal wall, the longitudinal component recorded the highest velocities, whereas at the surface geophone placed $35 \mathrm{ft}$ from the canal wall, the vertical component recorded the highest velocities (fig. 48).

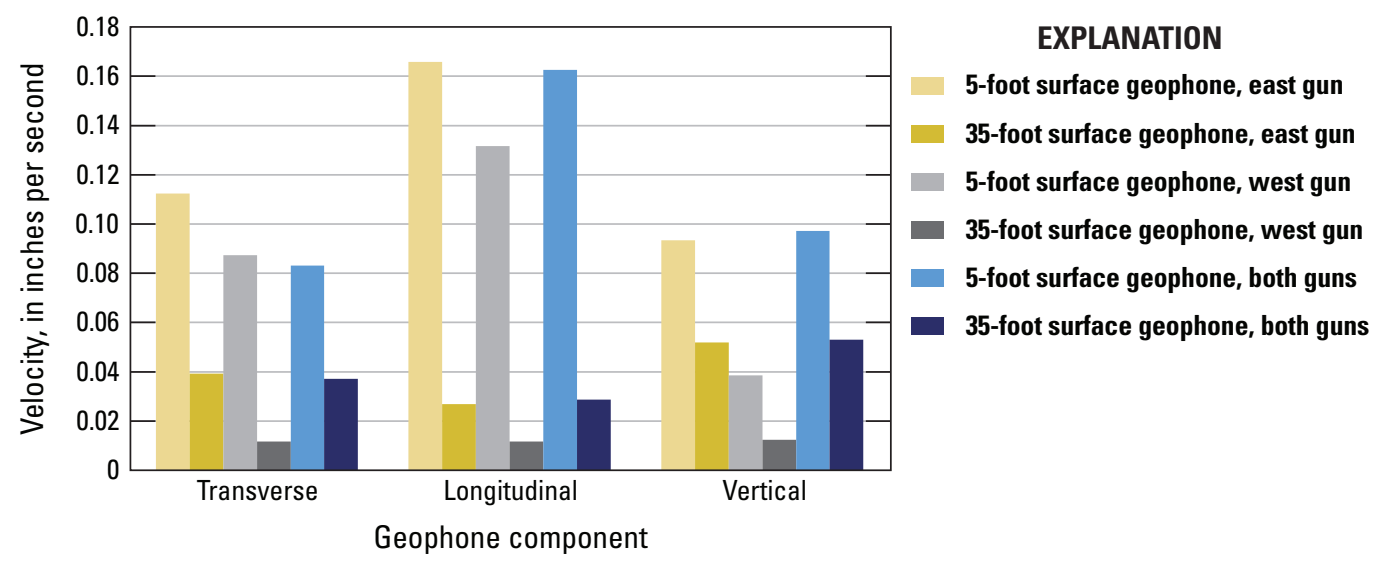

Figure 48. Highest velocities from water guns recorded by surface geophones during the 2011 replicate scenario for water guns placed 30 feet from the canal wall and fired at an input pressure of 2,000 pounds per square inch, Chicago Sanitary Ship Channel, near Lemont, Illinois.

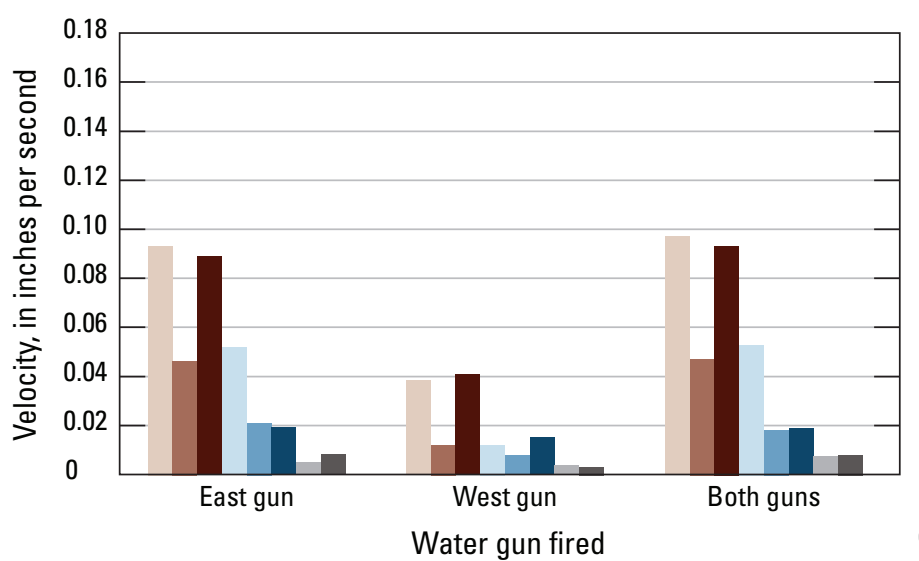

\section{EXPLANATION}

Geophone distance from canal wall - 5-foot surface geophone

5-foot shallow borehole geophone

- 5-foot deep borehole geophone 35 -foot surface geophone 35-foot shallow borehole geophone - 35-foot deep borehole geophone - 100-foot shallow borehole geophone 100-foot deep borehole geophone NOTE: Shallow, 5 feet below ground surface: deep, 20-25 feet below ground surface.

Figure 49. Highest vertical velocities from water guns recorded by surface and downhole geophones during the 2011 replicate scenario for water guns placed 30 feet from the canal wall and fired at an input pressure of 2,000 pounds per square inch, Chicago Sanitary Ship Channel, near Lemont, Illinois. 


\section{Double Gun Grid Scenario}

This scenario was run as a series of water gun shots with geophones placed in line and offset from the center line to determine how velocities varied with changing distance parallel to the canal wall. Velocity data were collected by surface geophones placed in a line with $10 \mathrm{ft}$ of separation (fig. 10A) and downhole geophones in the boreholes 5 and $35 \mathrm{ft}$ landward from the right bank canal wall. The center of the geophone line (between the white and green geophones) was aligned with the water guns so that offset geophones were $15 \mathrm{ft}$ upstream (pink) and $15 \mathrm{ft}$ downstream (red) and "in line" geophones were $5 \mathrm{ft}$ upstream (white) and $5 \mathrm{ft}$ downstream (green) of the water guns (fig. 10A). The 15-ft downstream (red) surface geophone remained next to the 5-ft landward borehole for quality assurance control between the 2011 replicate and double gun grid scenarios.

The highest recorded velocities were from the vertical component of the pink geophone (fig. 50) placed $15 \mathrm{ft}$ upstream of the center line. Here, the maximum velocity measured was $0.304 \mathrm{in} / \mathrm{s}$ from the firing of two water guns placed 40 and $120 \mathrm{ft}$ from the canal wall at 2,000 lb/in². This was the highest velocity measured on the canal wall between all three scenarios. Geophones of equal distance from the water gun center (pink and red, white and green) were examined to determine if they recorded similar velocities. In theory, geophones placed the same distance from the center line should record similar velocities. These velocity data were from data collected when the water gun was $40 \mathrm{ft}$ from the canal wall (fig. 50). Geophones placed the same distance from the center line did not produce similar velocities. The pink (15 ft upstream of center) geophone recorded the highest velocities compared to the other three geophones; the pink geophone recorded higher velocities compared to the red geophone (both $15 \mathrm{ft}$ downstream of center), and the white geophone recorded higher velocities compared to the green geophone (both $5 \mathrm{ft}$ downstream of center).

The maximum horizontal (transverse and longitudinal) velocities recorded at the red surface geophone placed $5 \mathrm{ft}$ from the canal wall are not as consistent as the maximum vertical velocities. Horizontal velocities vary by about $0.04 \mathrm{in} / \mathrm{s}$ with a ranges of about $0.09-0.13$ and $0.12-0.16 \mathrm{in} / \mathrm{s}$ for the transverse and longitudinal horizontal velocities, respectively. Vertical velocities vary by $0.01 \mathrm{in} / \mathrm{s}$ with a range of $0.09-0.10 \mathrm{in} / \mathrm{s}$. The borehole geophones recorded similar velocities between the scenarios compared to the surface geophones from a shot $40 \mathrm{ft}$ from the canal wall firing at a gun input pressure of 2,000 lb/in ${ }^{2}$ (fig. 51). The maximum recorded velocities at the surface geophone do not always occur during the single gun firing. A double gun firing produced the maximum velocity for the vertical component.

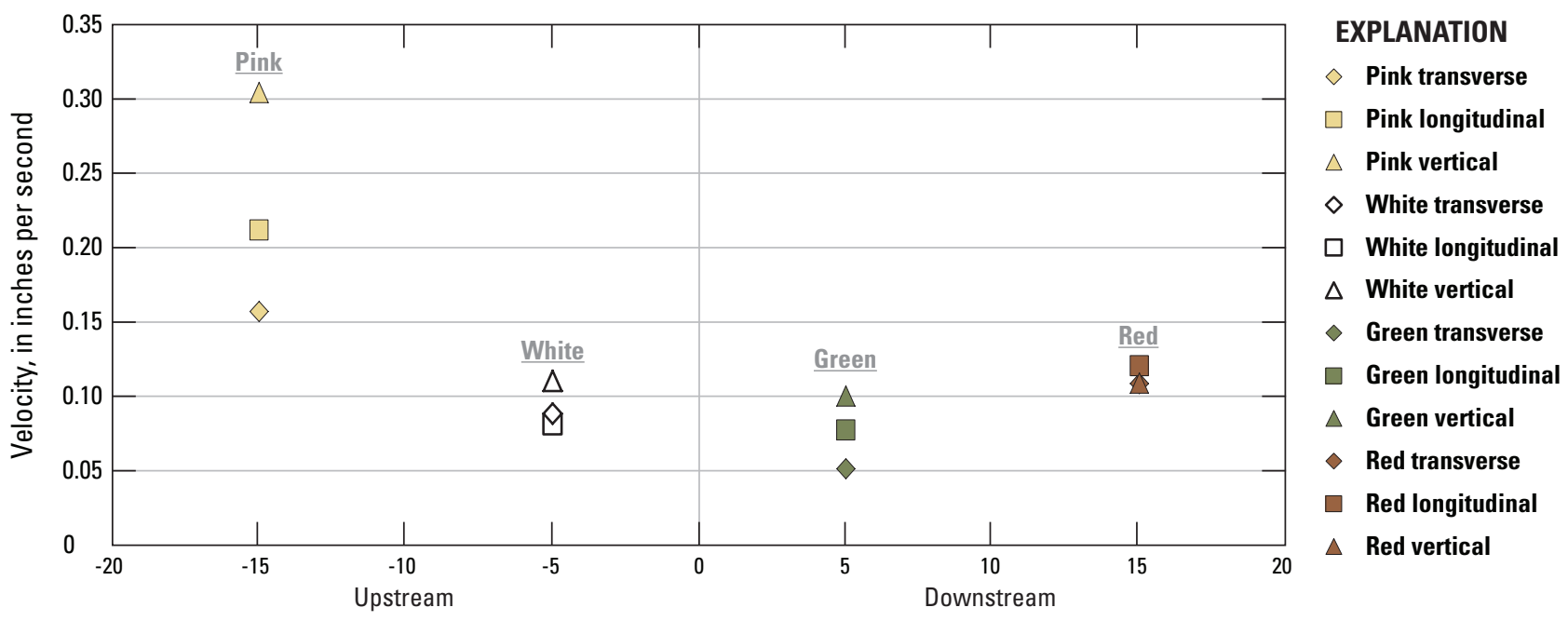

Geophone offset from line to gun platform center line, in feet

Figure 50. Geophone positions along the canal wall relative to water gun center line and velocities recorded at each position from a water gun fired about 40 feet from the wall at a depth of 14 feet below water surface, Chicago Sanitary Ship Channel, near Lemont, Illinois. 


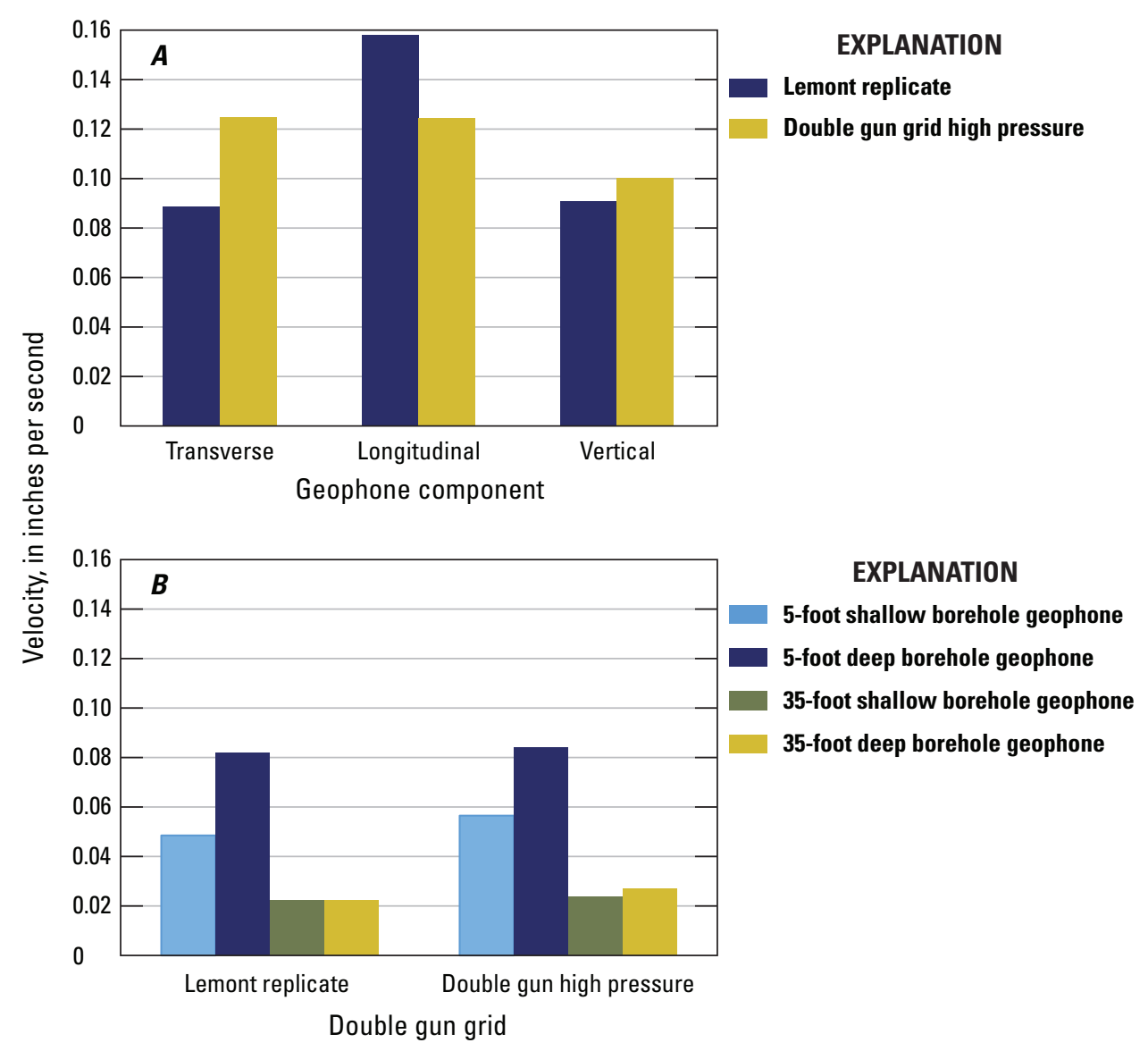

Figure 51. Maximum velocities recorded for the 2011 replicate scenario and the double gun grid scenario high pressure trial by the red surface geophone placed 5 feet from the canal wall $(A)$ and borehole geophones $(B)$ placed 5 and 35 feet from the canal wall, Chicago Sanitary Ship Channel, near Lemont, Illinois.

The double gun grid scenario low pressure trial was run with the same water gun setup as the double gun grid scenario high pressure trial, but with the water gun input pressure decreased to $1,000 \mathrm{lb} / \mathrm{in}^{2}$. The geophone placements were changed, resulting in an L-shaped grid with $10 \mathrm{ft}$ of separation (fig. 10B) so that comparisons could be made to the Brandon Road Lock and Dam data sets setup in a grid with $10 \mathrm{ft}$ of separation. The water guns were centered in the middle of the channel so that the white and blue geophones were placed $5 \mathrm{ft}$ upstream of the center line and the green and pink geophones were placed $5 \mathrm{ft}$ downstream of the center line. The center of the grid formed by these four geophones made a perpendicular line relative to the canal wall. The red surface geophone remained next to the 5 - $\mathrm{ft}$ borehole $15 \mathrm{ft}$ downstream of the center line for quality assurance control between the scenarios.
The velocity differences between a typical single 1,000 and 2,000 lb/in ${ }^{2}$ water gun shot fired $40 \mathrm{ft}$ from the canal wall and recorded at the red surface geophone placed $15 \mathrm{ft}$ downstream and $5 \mathrm{ft}$ from the canal wall are shown in figure 52 . The peak ground velocity decreases with the decrease in gun input pressure, but not proportionally.

Velocities recorded at each geophone in the grid (fig. 10B) from the firing of a single water gun $40 \mathrm{ft}$ from the canal wall at an input pressure of $1,000 \mathrm{lb} / \mathrm{in}^{2}$ are shown in figure 53. The blue geophone ( $5 \mathrm{ft}$ upstream of and $15 \mathrm{ft}$ landward from wall) recorded the highest vertical component velocity, and the green geophone ( $5 \mathrm{ft}$ downstream of and $5 \mathrm{ft}$ landward from wall) recorded the highest longitudinal component velocity. 


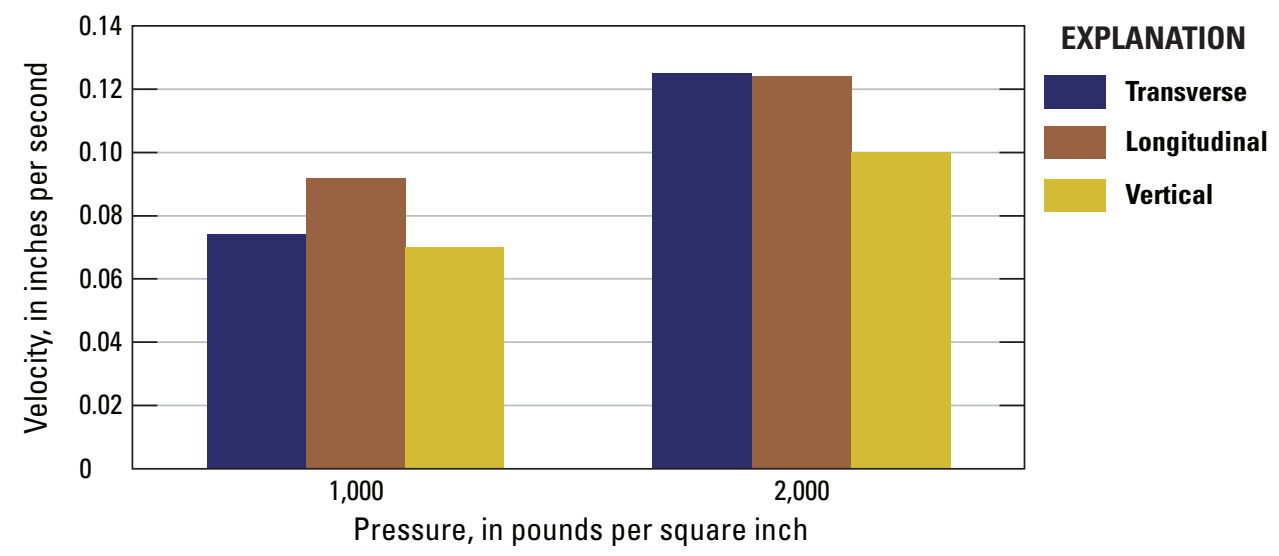

Figure 52. Transverse, longitudinal, and vertical velocities of a single water gun with input pressures of 1,000 and 2,000 pounds per square inch placed 40 feet from the canal wall, as measured by the red surface geophone placed 15 feet downstream of the center line and 5 feet from the canal wall, Chicago Sanitary Ship Channel, near Lemont, Illinois.

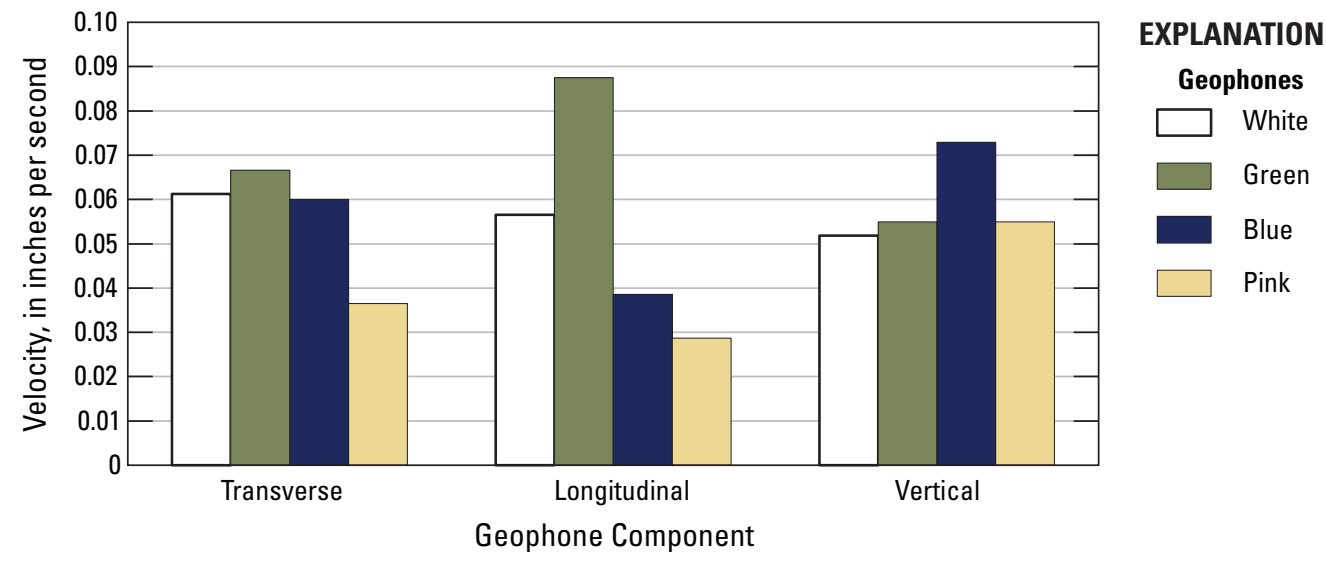

Figure 53. Transverse, longitudinal, and vertical velocities of a single water gun with input pressure of 1,000 pounds per square inch placed 40 feet from the canal wall and 14 feet below water surface, as measured by surface geophones placed 5 and 15 feet from the canal wall and offset either 5 feet upstream (white and blue) or 5 feet downstream (green and pink) of the water gun, Chicago Sanitary Ship Channel, near Lemont, Illinois. 


\section{Acceleration}

Acceleration data were collected by two singlecomponent (horizontal and vertical) accelerometers mounted on the wall of the canal. The accelerometers were placed directly in line with the water guns, with the horizontal unit monitoring the movement of the wall directly toward or away from the canal (longitudinal component) and the vertical unit monitoring the movement of the wall up and down (vertical component). The two accelerometers were attached to an aluminum mounting block secured to the dolomite setblock wall about $2 \mathrm{ft}$ down from the top of the wall and about 5-6 ft above the water. These sensors remained in the same position throughout the duration of the study.

Vertical acceleration upward and horizontal acceleration out of the canal wall decreased with decreasing distance to the wall, with a sharp decrease in acceleration towards zero at shot distances of 40-60 ft (fig. 54). Vertical acceleration downward and horizontal acceleration into the canal wall increased with decreasing distance from the wall, with a sharp change in acceleration towards zero at shot distances of 40-60 ft. Some possibilities for these small acceleration rates may be poor coupling of the block into the dolomite, or poor coupling into the weathered/weak dolomite. Acceleration rates into the canal wall and downward produced almost a mirror image of their positive counterparts, but with a smaller range of values $\left(0.025 \mathrm{ft} / \mathrm{s}^{2}\right.$ compared to $\left.0.153 \mathrm{ft} / \mathrm{s}^{2}\right)$. These were trends for both single gun shots as well (data not shown); however, double gun shots produced almost double acceleration rates out of the wall and upward compared to single gun shots.

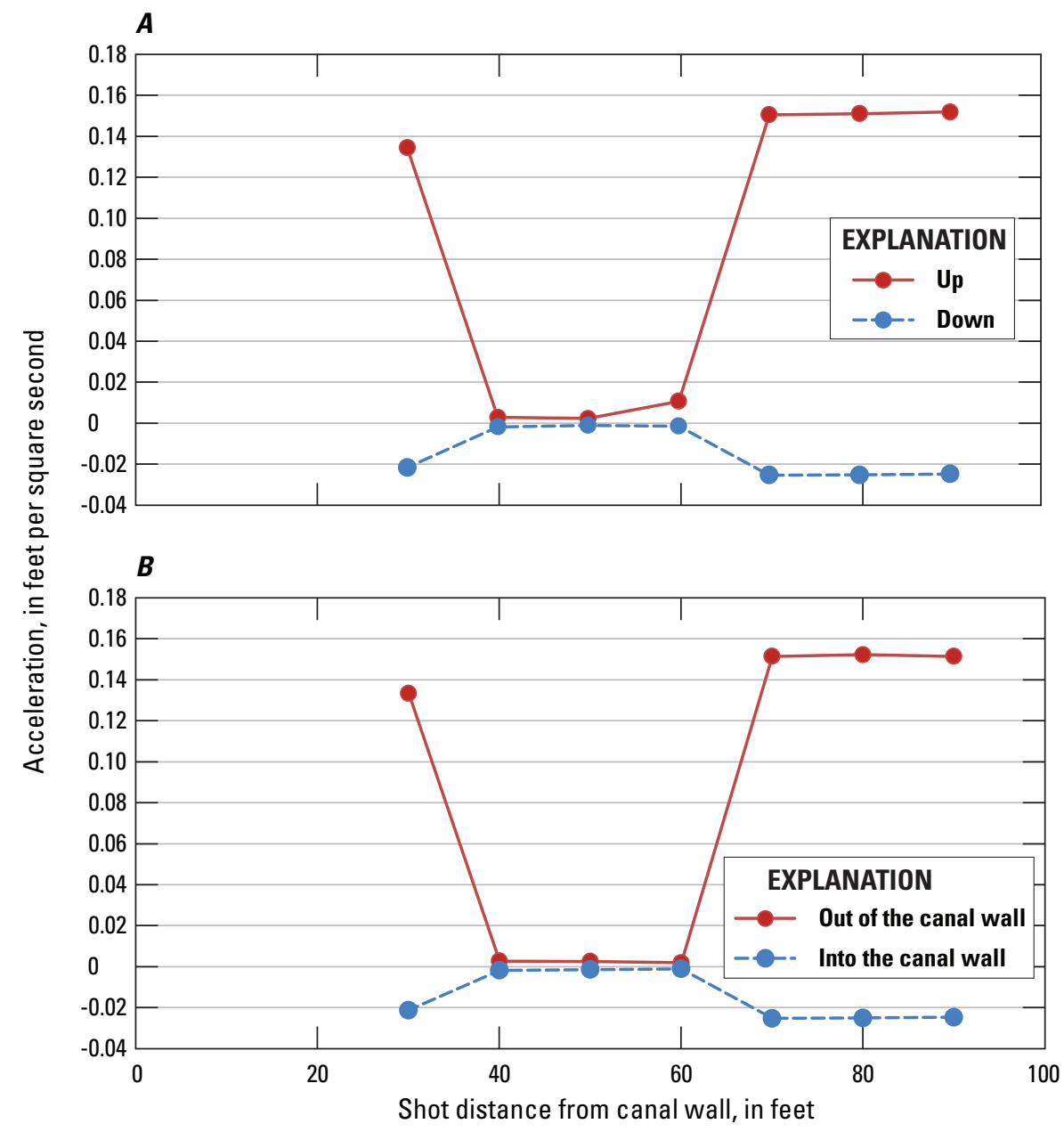

Figure 54. Changes in acceleration of pressure wave velocities as water gun distance to the canal wall decreases for the vertical $(A)$ and horizontal $(B)$ components of a double gun firing 40 and 120 feet from the canal wall, Chicago Sanitary Ship Channel, near Lemont, Illinois. 
Acceleration rates into the wall as well as downward between single gun and double gun firings were relatively similar. The maximum recorded acceleration rates were a $0.15 \mathrm{ft} / \mathrm{s}^{2}$ vertical upward movement and a $0.15 \mathrm{ft} / \mathrm{s}^{2}$ horizontal movement out of the wall when two water guns placed $80 \mathrm{ft}$ from the canal wall were fired simultaneously. Changes in acceleration as water gun distance decreases firing both water guns at $2,000 \mathrm{lb} / \mathrm{in}^{2}$ are shown in figure 54. Five water gun shots were taken at each point location. For each shot, the maximum acceleration rate was recorded (data were logged every 0.0625 millisecond for $3 \mathrm{~s}$ following firing). The arithmetic mean of the five maximum acceleration rates was recorded at each position.

\section{Comparison of Hydrophone Data from Different Water-Gun Configurations}

These two studies measured the underwater pressure field created by a water gun or water guns within two navigable water channel environments. The channel to the Brandon Road Lock and Dam has about one-half the depth and two-thirds the width of the segment of the CSSC near Lemont. The channel geometry and construction are similar, however. Both channels are artificially constructed with a rectangular cross section and walls made of imported building materials (concrete at Brandon Road and dolomite setblock at Lemont).

The operational parameters also had similarities and differences. Lower firing pressures due to limitations set by USACE engineers resulted in the restriction of input pressure from the Brandon Road single gun radial trial gun to $700 \mathrm{lb} / \mathrm{in}^{2}$ compared to the setting of input pressure from the Lemont single gun trial at $1,000 \mathrm{lb} / \mathrm{in}^{2}$. Water guns were fired at Brandon Road at 2,000 lb/in' ${ }^{2}$, but only five times. Water gun positions were limited by channel size. Water guns could only be moored together at Brandon Road to maintain maximum distance from both walls, whereas at Lemont, water guns had to be moored separately to cover the wider channel.

Pressure and distance comparisons for single water guns fired at $1,000 \mathrm{lb} / \mathrm{in}^{2}$ at Brandon Road and at Lemont are shown in figure 55 . These values represent the three-dimensional distance from the water gun or guns to the hydrophone. The three-dimensional distance was calculated using the Pythagorean Theorem to determine the length of the line segment drawn directly from the centroid of the water gun location to the centroid of the hydrophone location in question. In the case of multiple water guns, data at Brandon Road were measured from the midpoint between the co-located water guns, and data from Lemont always were measured from the easternmost water gun (restrictions in hydrophone cable length resulted in a greater data density surrounding this gun).
Data from Brandon Road (fig 55A) follow an approximate exponential trend of decreasing pressure with distance. Relative pressure variation between the hydrophones also decreases with distance from the water gun, with the highest pressures nearest the bottom of the channel and the lowest pressures at the water surface. Data from Lemont (fig. 55B) likely were recorded at a distance beyond the inflection point of the exponential trend observed at Brandon Road and also were beyond the point at which the intensity with depth relation normalizes.

Data recorded at comparable distances (20-50 ft) showed two different trends. Data from Brandon Road decreased from about $3 \mathrm{lb} / \mathrm{in}^{2}$ to $1 \mathrm{lb} / \mathrm{in}^{2}$, whereas data from Lemont remained static at about $3 \mathrm{lb} / \mathrm{in}^{2}$. Given that these water guns were placed in roughly the same relative position (the same proportional distance from the testing wall and with the water gun suspended at about the mid-depth of the channel), additional depth present at Lemont (about $9 \mathrm{ft}$ of water below the water gun as compared to about $3 \mathrm{ft}$ at Brandon Road) may result in a smaller loss of pressure.

Pressure and distance comparisons for two water guns fired at $1,000 \mathrm{lb} / \mathrm{in}^{2}$ are shown in figure 56 . For these trials, the water guns were fired at the same pressure, but were deployed differently. At Brandon Road, the water guns were moored together with the guns suspended at 6 and $8 \mathrm{ft}$ bws, whereas at Lemont, the two platforms were separated by $80 \mathrm{ft}$ with both water guns suspended at $14 \mathrm{ft}$ bws.

Trends in pressure over distance were similar to the single gun data discussed earlier in this section. Data from Brandon Road (fig. 56A) showed an exponential trend of decreasing pressure with distance, whereas data from Lemont (fig. 56B) showed static pressure with distance. Over a comparable distance (40-60 ft), pressures at Brandon Road decreased from 6 to $3 \mathrm{lb} / \mathrm{in}^{2}$, whereas pressures at Lemont remained constant at $3 \mathrm{lb} / \mathrm{in}^{2}$.

The addition of a second water gun was more apparent at Brandon Road. The maximum pressure recorded was nearly double that of the single gun data. The extent of the $5-1 \mathrm{~b} / \mathrm{in}^{2}$ contour doubled from 20 to $40 \mathrm{ft}$.

Pressures at Lemont indicated that, although the intensity of this water gun deployment was lower than the pressures at Brandon, the range at which the target pressure can be projected is larger. Pressures at Lemont remained constant from $20 \mathrm{ft}$ until at least $85 \mathrm{ft}$, whereas pressures at Brandon trended toward 0 at $55 \mathrm{ft}$.

This tradeoff of initial intensity compared to greater range likely is the result of the water gun configuration. The location of water guns close to each other seemingly resulted in an increase in the intensity close to the gun, but only a small increase in the range. Increasing the distance between the water guns showed the reverse- a decrease in initial intensity, but an increase in range. 


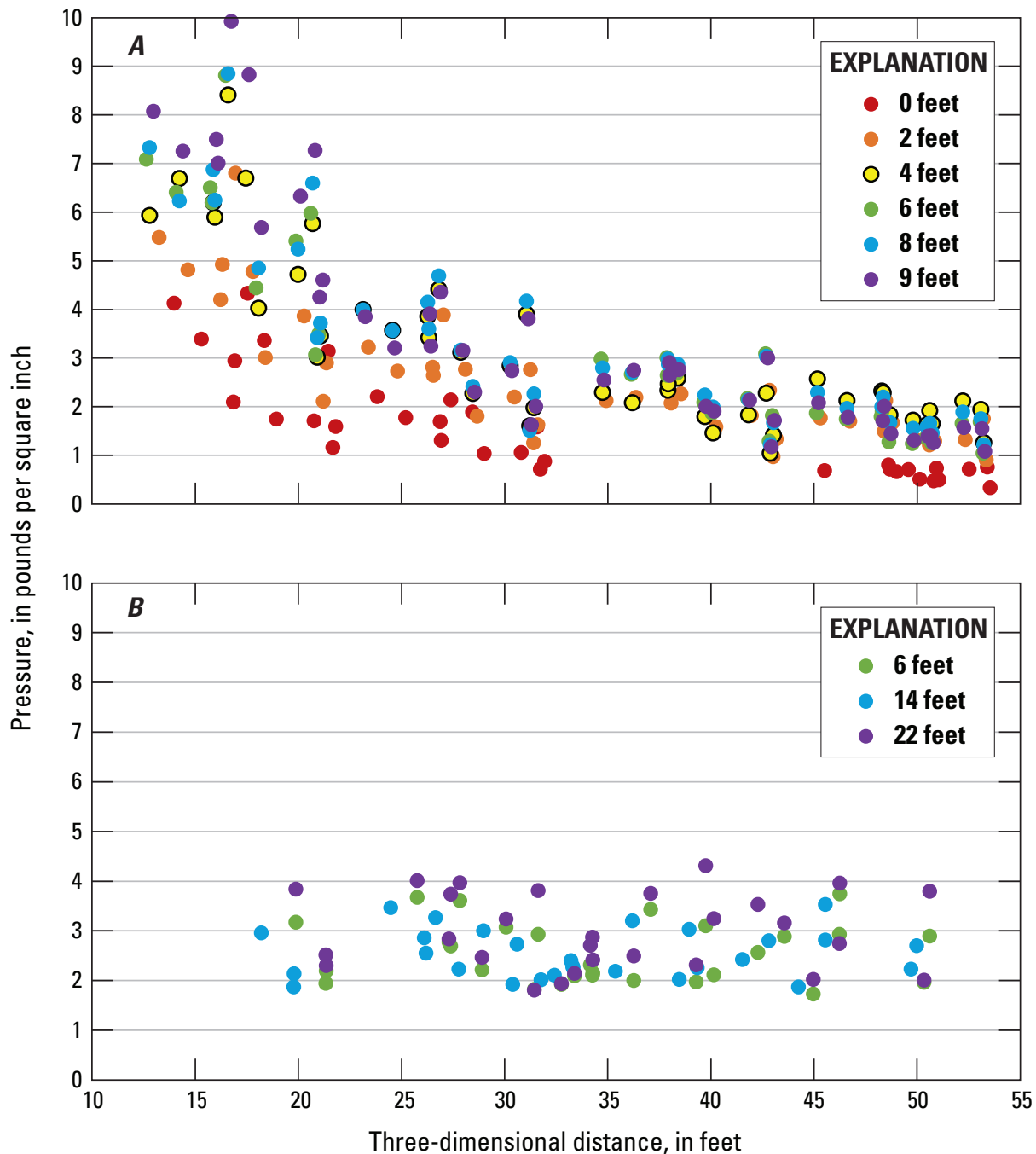

Figure 55. Changes in water pressure as three-dimensional distance from water guns(s) to hydrophone increases when firing one 80-cubic-inch water gun at 1,000 pounds per square inch at $(A)$ Brandon Road study area, Des Plaines River, near Joliet, Illinois; and $(B)$ Lemont study area, Chicago Sanitary Ship Channel, near Lemont, Illinois. 


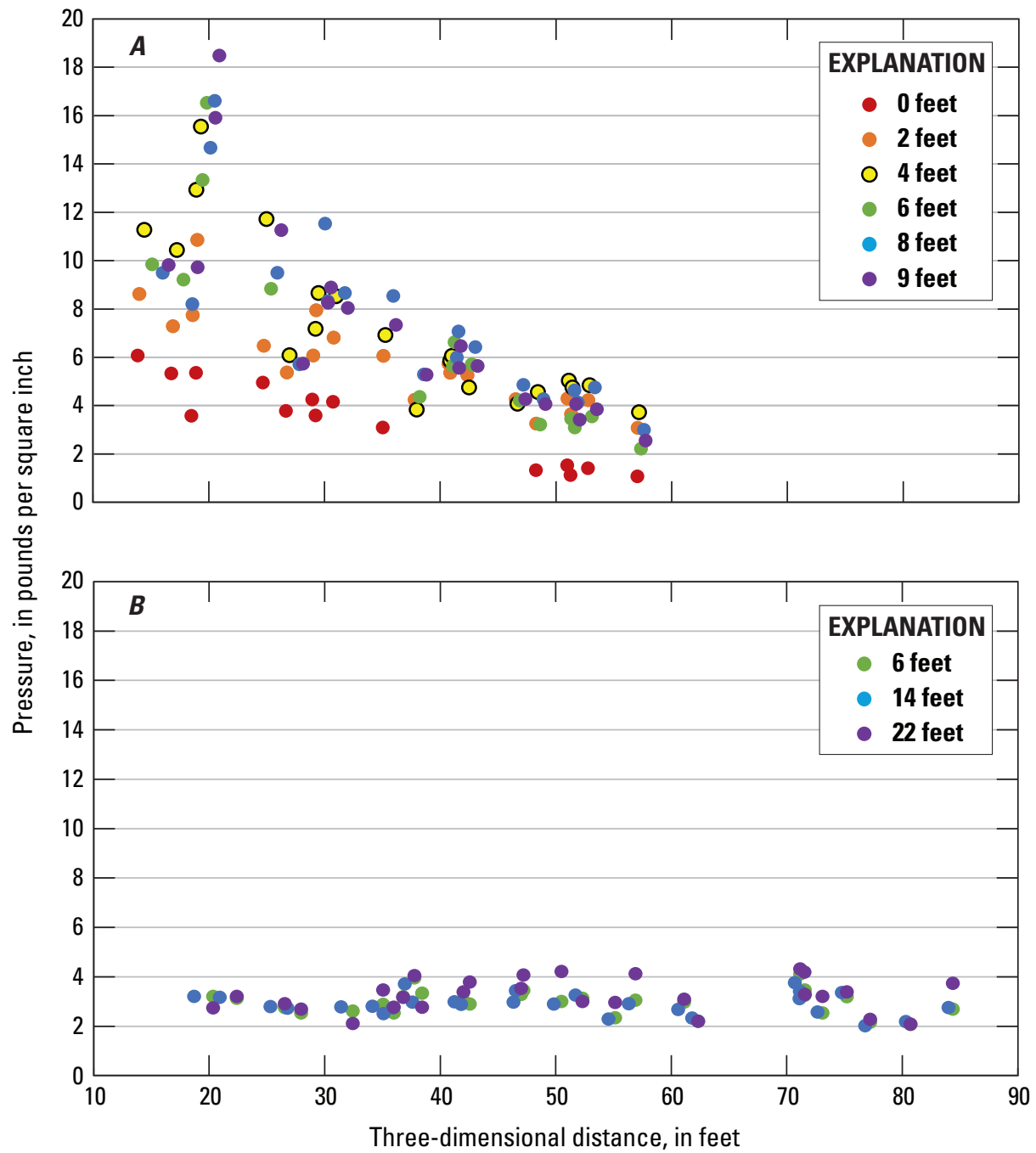

Figure 56. Changes in water pressure as three-dimensional distance from water guns to hydrophone increases when firing two 80 -cubic-inch water guns at 1,000 pounds per square inch at $(A)$ Brandon Road study area, Des Plaines River, near Joliet, Illinois; and $(B)$ Lemont study area, Chicago Sanitary Ship Channel, near Lemont, Illinois. 
This conclusion is corroborated by data from the 2011 replicate scenario at Lemont and the Brandon Road double gun radial scenario. Data collected at Lemont are shown in figure $35 \mathrm{~A}$ and $C$. Comparing the values from a single gun at $14 \mathrm{ft}$ bws and both guns at 4 and $14 \mathrm{ft}$ bws, there was only a small increase in the pressure recorded despite the addition of a second water gun firing at $2,000 \mathrm{lb} / \mathrm{in}^{2}$. Data collected at Brandon are shown in figure $20 \mathrm{~A}$ and $C$. The addition of a second water gun did not result in a substantial change in the extent of the $5-\mathrm{lb} / \mathrm{in}^{2}$ contour.
Pressure and distance comparisons from two water guns fired at 2,000 lb/in ${ }^{2}$ are shown in figure 57. Data from Brandon Road (fig. 57A) are similar to previous iterations at different pressures. Data from Lemont (fig 57B) are slightly different from data of the two previous examples (figs. 55B and 56B). Pressures show a decreasing linear trend over distance compared to the nearly static relation shown in the $1,000-\mathrm{lb} / \mathrm{in}^{2}$ trials. Trends in figure $57 \mathrm{~B}$ are more similar to those in figures $55 \mathrm{~A}$ and $56 \mathrm{~A}$, indicating the decaying limb of the exponential trends shown in those examples. The increase in firing pressure possibly results in a higher intensity near the gun and the similarities to the trends shown in the Brandon Road data.

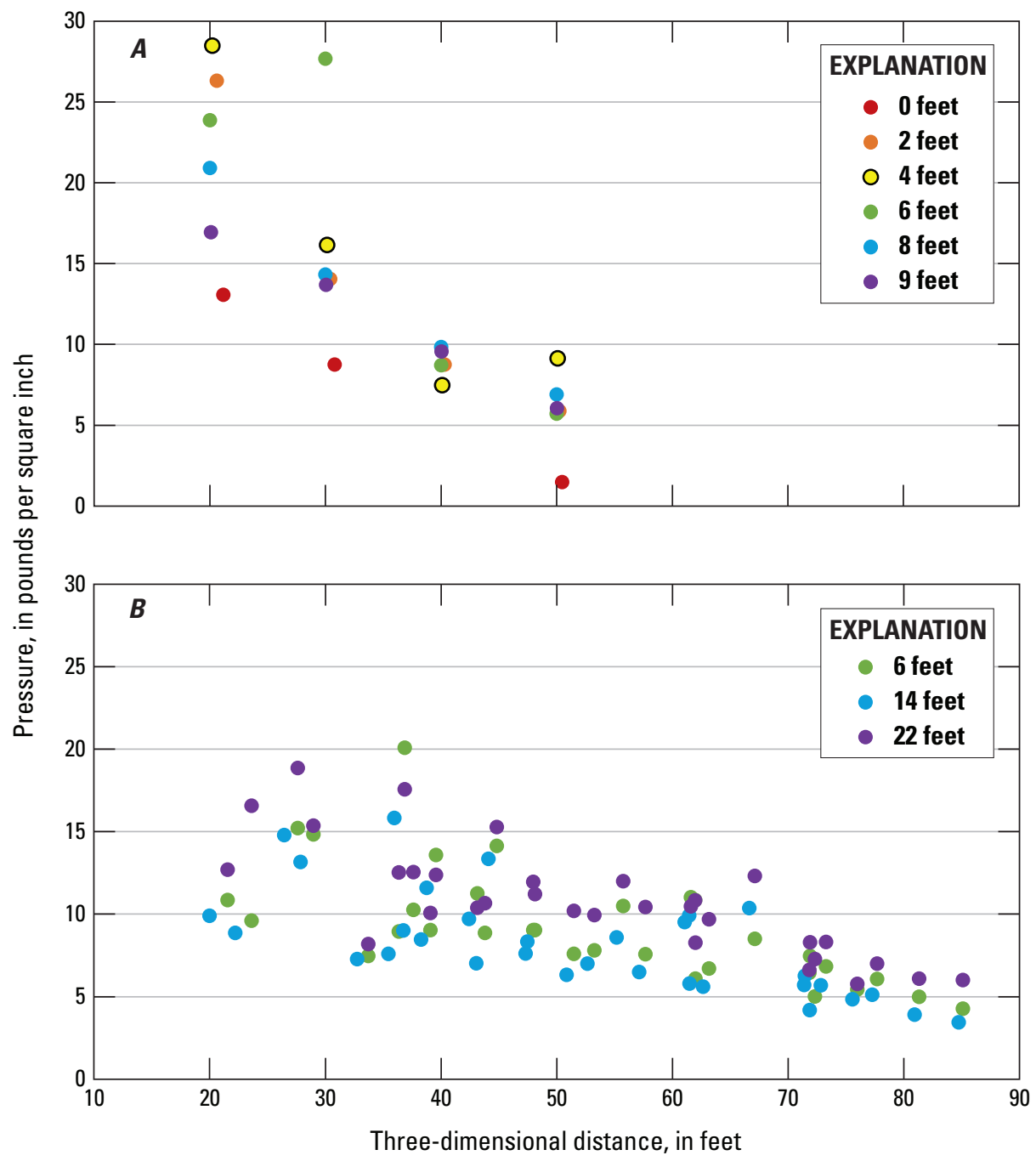

Figure 57. Changes in water pressure as three-dimensional distance from water guns to hydrophone increases when firing two 80-cubic-inch water guns at 2,000 pounds per square inch at $(A)$ Brandon Road study area, Des Plaines River, near Joliet, Illinois; and (B) Lemont study area, Chicago Sanitary Ship Channel, near Lemont, Illinois. 


\section{Summary}

Two species of invasive Asian carps (bighead carps [Hypophthalmichthys nobilis] and silver carps [Hypophthalmichthys molitrix]) have the potential to move into the Great Lakes from the Mississippi River Basin. The U.S. Geological Survey (USGS), in cooperation with the U.S. Environmental Protection Agency, Great Lakes Restoration Initiative, is evaluating the underwater pressure field and ground vibrations produced from the firing of a seismic water gun and its potential effectiveness of producing a pressure barrier to prevent or direct the movement of the Asian carps while ensuring the integrity of surrounding structures. Underwater pressure data were collected by blast-rated hydrophones and blast sensors. Velocity and acceleration data at structures adjacent to the water guns were collected by three-component geophones and fixed accelerometers.

Two studies, one each in May and June 2014, were carried out in two navigable waterway locations - the downstream approach channel of the Brandon Road Lock and Dam near Joliet, Illinois, and a segment of the Chicago Sanitary and Ship Canal near Lemont, Illinois. A limit of 5 pounds per square inch $\left(5 \mathrm{lb} / \mathrm{in}^{2}\right)$ dynamic underwater pressure variation was established based on previous fish studies. A limit of 0.75 inches per second (in/s) surface ground velocity also was established to preserve the structural integrity of the canal walls.

The purpose of the May 2014 study at Brandon Road was to understand the magnitude and extent of the pressure field created by 80 -cubic-inch $\left(\mathrm{in}^{3}\right)$ water guns in the concrete-walled channel downstream of the lock. Additionally, parameters of the water guns (distance to canal wall and pressure) were changed to understand the effects on wall velocity. A single $80-\mathrm{in}^{3}$ gun produced a roughly cylindrical pressure field with a maximum extent of 20 feet (ft) for the $5 \mathrm{lb} / \mathrm{in}^{2}$ threshold pressure, with a water gun input pressure of $700 \mathrm{lb} / \mathrm{in}^{2}$ at a depth of $6 \mathrm{ft}$ below water surface (bws). Pressures generally increased with depth, but the size of the 5-lb/in ${ }^{2}$ threshold area decreased above and below the water gun depth, extending to less than $15 \mathrm{ft}$ at the water surface. The addition of a second 80 -in ${ }^{3}$ water gun, placed directly adjacent to the first water gun positioned at $6 \mathrm{ft}$ bws and orthogonally to that gun at a depth of $8 \mathrm{ft}$ bws, increased the maximum extent of the $5-1 \mathrm{~b} / \mathrm{in}^{2}$ threshold pressure to $30 \mathrm{ft}$. Neither of the water gun configurations exceeded the given threshold of $5 \mathrm{lb} / \mathrm{in}^{2}$ above the static pressure along the walls of the canal at the $700-\mathrm{lb} / \mathrm{in}^{2}$ water gun input pressure.

The maximum recorded velocity of pressure waves from water guns fired at Brandon Road was $0.239 \mathrm{in} / \mathrm{s}$ - less than the $0.75 \mathrm{in} / \mathrm{s}$ sensitive machinery limit. Velocity data collected at the water surface near the wall of the channel showed changes relative to water gun input pressure and the number of water guns. Velocity data also showed a greater response in the vertical component relative to the horizontal component. Velocity data collected near the wall of the channel showed little change with respect to water gun depth, orientation, and distance from the wall. Maximum acceleration values were $0.0188 \mathrm{ft} / \mathrm{s}^{2}$ in the upward direction.

In the June 2014 study at Lemont, data were collected to further define and increase the resolution of data collected in the 2011 study to evaluate the response of the canal wall to 80 -in ${ }^{3}$ water guns. Water pressures were mapped in a larger and more defined areal and depth pattern than in the previous 2011 study. The extent, shape, and magnitude of the pressure fields recorded at Lemont differed in comparison to data collected previously at Brandon Road. The pressure field varied substantially with respect to water gun input pressure. Coverage of the $5-\mathrm{lb} / \mathrm{in}^{2}$ pressure threshold was consistent over nearly the entire measured area using a 2,000-lb/in ${ }^{2}$ gun input pressure at $40 \mathrm{ft}$, whereas minimal coverage of the $5-\mathrm{lb} / \mathrm{in}^{2}$ threshold pressure over the measured area was obtained using a 1,000-lb/in ${ }^{2}$ gun input pressure at $40 \mathrm{ft}$. Although the Lemont pressure data followed trends similar to those at Brandon Road (in showing an increase in pressure with depth), the size and shape of the pressure field data at Lemont differed (maximum extent of the pressure field for a single gun did not occur at the gun depth).

The maximum recorded velocity of pressure waves from water guns fired at Lemont was $0.304 \mathrm{in} / \mathrm{s}$ - less than the $0.75 \mathrm{in} / \mathrm{s}$ sensitive machinery limit. Velocity data showed changes in water gun depth and distance from the wall. Velocity data near the canal wall did not vary greatly with water gun input pressure and number of water guns. Maximum acceleration values were $0.15 \mathrm{ft} / \mathrm{s}^{2}$ both in the upward direction and out of the canal wall.

Although water gun input pressures, water gun depth, and water gun orientation varied between the testing locations, the underwater pressure results suggest that, where possible, water guns placed at a set distance from each other are more efficient at transmitting pressure at distance in the water than water guns placed adjacent to each other.

\section{Acknowledgments}

The authors acknowledge the field crews from the U.S. Geological Survey Illinois-Iowa Water Science Center and Upper Midwest Environmental Sciences Center, and Northern Illinois University for collecting the data that made this report possible. 


\section{References Cited}

Adams, R.F., and Morrow, W.S., 2015, Geophysical investigation of the pressure field produced by water guns at a pond site in La Crosse, Wisconsin: U.S. Geological Survey Open-File Report 2015-1130, 56 p., https://dx.doi. org/10.3133/ofr20151130.

Adams, R.F., Morrow, W.S., and Koebel, C.M., 2017, Seismic water gun data collected at Brandon Road Lock and Dam near Joliet and in the Chicago Sanitary and Ship Canal near Lemont, Illinois: U.S. Geological Survey data release, https://doi.org/10.5066/F7KK990W.

Gross, J.A., Irvine, K.M., Wilmoth, S., Wagner, T.L., Shields, P.A., and Fox, J.R., 2013, Effects of pulse pressure from seismic water gun technology on Northern pike: Transactions of the American Fisheries Society, v. 142, no. 5 , p. 1,335-1,346.

Keevin, T.M., and Hempen, G.L., 1997, The environmental effects of underwater explosions with methods to mitigate impacts: U.S. Army Corps of Engineers St. Louis District, SDMS Doc ID 550560, 99 p.

Layhee, M.J., Gross, J.A., Parsley, M.J., Romine, M.J., Glover, D.C., Suski, C.D., Wagner, T.L., Sepulveda, A.J., and Gresswell, R.E., 2013, Asian carp behavior to static water gun firing: U. S. Geological Survey Fact Sheet 2013-3098, 4 p.

Lokkeborg, S., Ona, E., Vold, A., and Salthaug, A., 2012, Sounds from seismic air guns - Gear- and species-specific effects on catch rates and fish distribution: Canadian Journal of Fisheries and Aquatic Sciences, v. 69, p. 1,278-1,291.

Morrow, W.S., Carpenter, P.J., and Adams, R.F., 2015, Seismic data collection from water guns and industrial background sources in the Chicago Sanitary and Ship Canal Area, Illinois, 2011: U.S. Geological Survey Data Series 938, $23 \mathrm{p}$.
Romine, J.G., Jensen, N.R., Parsley, M.J., Gaugush, R.F., Severson, T.J., Hatton, T.W., Adams, R.F., and Gaikowski, M.P., 2015, Response of bighead carp and silver carp to repeated water gun operation in an enclosed shallow pond: North American Journal of Fisheries Management, v. 35, no. 3, p. 440-453, http://dx.doi.org/10.1080/0275594 7.2015.1012279.

Siskind, D.E., Stagg, M.S., Kopp, J.W., and Dowding, J.H., 1980, Structural response and damage produced by ground vibration from surface mine blasting: U.S. Bureau of Mines Report of Investigations 8507-1980, 74 p.

Turnpenny, A.W.H., and Nedwell, J.R., 1994, The effects on marine fish, diving mammals and birds of underwater sound generated by seismic surveys: Fawlay Aquatic Research Lab Report Reference FCR 089/94:UKOOA, 50 p.

U.S. Army Corps of Engineers, 2011, The electric dispersal barriers brochure: U.S. Army Corps of Engineers Chicago District, accessed May 18, 2016, at http://www.asiancarp. us/documents/BarrierBrochure.pdf.

U.S. Army Corps of Engineers, 2015, Brandon Road lock and dam fact sheet: U.S. Army Corps of Engineers Rock Island District, Illinois, accessed November 2015, at http://www. mvr.usace.army.mil/Portals/48/docs/CC/FactSheets/IL/ BrandonRoadLockandDam(2015).pdf.

Wardle, C.S., Carter, T.J., Urquhart, G.G., Johnstone, A.D.F., Ziolkowski, A.M., Hampson G., and Mackie, D., 2001, Effects of seismic air guns on marine fish: Continental Shelf Research, v. 21, p. 1,005-1,027. 

Publishing support provided by the U.S. Geological Survey

Science Publishing Network, Tacoma Publishing Service Center

For more information concerning the research in this report, contact the Director, Illinois Water Science Center

U.S. Geological Survey

$405 \mathrm{~N}$ Goodwin

Urbana, IL 61801

https://il.water.usgs.gov 
